\title{
Insights into the structural evolution of the pre-Variscan rocks of the Eastern Pyrenees from La Molina quartz veins; constraints on chlorite and fluid inclusion thermometry
}

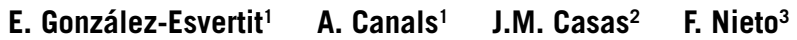 \\ 'Departament de Mineralogia, Petrologia i Geologia Aplicada, Facultat de Ciències de la Terra, \\ Universitat de Barcelona \\ Martí i Franquès s/n, Barcelona, 08028, Spain. González-Esvertit E-mail: eloige@gmail.com \\ 2Departament de Dinàmica de la Terra i de l'Oceà, Facultat de Ciències de la Terra, \\ Universitat de Barcelona \\ Martí i Franquès s/n, Barcelona, 08028, Spain \\ ${ }^{3}$ Departamento de Mineralogía y Petrología, Instituto Andaluz de Ciencias de la Tierra, \\ Universidad de Granada-CSIC \\ Avenida Fuentenueva s/n, Granada, 18002, Spain
}

\begin{abstract}
Quartz veins hosted in the infra and overlying series to the (Sardic) Upper Ordovician Unconformity provide new insights into the structural and thermal evolution of the pre-Variscan rocks of the Eastern Pyrenees. In the La Molina area (Canigó massif), two generations of metric-scale quartz veins (V1 and V2) are distinguished by their distribution patterns and their relationship with deformational macro, meso, and microstructures. P-T formation conditions are obtained by combining chlorite geothermometry and fluid inclusion microthermometry data. Discrepancies on formation temperature for chlorites located at different positions within the veins are discussed, concluding that veins grew in a low fluid/rock ratio regime. V1 veins can be related to the Late Ordovician synsedimentary faulting episode as revealed by their distribution patterns, formation mechanisms, and fluid-rock interactions. We propose an Alpine age for the V2 veins, based on their structure and the emplacement conditions of $318 \pm 12^{\circ} \mathrm{C}$ and $2.4 \pm 0.2 \mathrm{kbar}$, with an estimated geothermal gradient of $34^{\circ} \mathrm{C} \cdot \mathrm{km}^{-1}$ and a burial depth of ca. $9 \mathrm{~km}$. Results obtained here are compared with other quartz veins spread throughout the Palaeozoic basement of the Eastern Pyrenees.
\end{abstract}

\begin{tabular}{l|l}
\hline KEYWORDS & Quartz veins. Pyrenees. P-T conditions. Chlorite.
\end{tabular}

\section{INTRODUCTION}

Quartz veins of variable sizes are common features in orogenic settings and their study may shed light on the evolution of orogens (Bons et al., 2012; Sharp et al., 2005, among others). In the Eastern Pyrenees, a number of quartz veins are present that vary from kilometric to metric lengths and decametric to centimetric widths, respectively (Ayora and Casas, 1983; Fonseca et al., 2015). These veins are mostly hosted in Variscan and pre-Variscan rocks, but on the southeastern slope of the chain (Roc de Frausa massif), quartz bodies that crosscut Mesozoic sedimentary rocks have also been recognised. 
West of the Roc de Frausa massif, on the southern slope of the Canigó massif, several quartz veins crop out in the Upper Ordovician and underlying Cambrian-Ordovician successions. Casas et al. (2019) and Puddu et al. (2019), based on the veins arrangement and distribution, suggested an Upper Ordovician fluid circulation event, which was genetically linked to the Middle-Upper Ordovician "Sardic" geodynamics. Specifically, Santanach (1972a) described the Upper Ordovician Unconformity in this area for first time in the Pyrenees, now widely recognised and used for Palaeozoic stratigraphic correlations in southwestern Europe. However, the origin and significance of this so-called Sardic Unconformity are still subject to open debate (Álvaro et al., 2018). As this area has registered complex evolution from Ordovician to Miocene times, more criteria are necessary to establish the age of the veins.

In this paper we deal with the structure, distribution and textural characteristics of quartz veins and their hosting rocks in La Molina area (Canigó massif), together with phyllosilicate chemistry and fluid inclusion microthermometry. The obtained data allow us to discuss: 1) the thermal balance between fluids and host rocks, and 2) the emplacement of quartz veins within the framework of the structural evolution of the pre-Variscan rocks of the Eastern Pyrenees. Moreover, differences in chlorite composition related to veingeneration and vein-location call into question the validity of the applied geothermometers for some of the analysed chlorites.

\section{GEOLOGICAL SETTING}

The Pyrenees is an Alpine fold-and thrust belt formed from the Late Cretaceous to Miocene by the collision between the Iberian and Eurasian plates (Muñoz, 1992a). In the central area of the orogen, cortical-scale Alpine antiformal stacking (Muñoz, 1992a) produced the exhumation of a pre-Variscan metasedimentary succession, Late Neoproterozoic to Carboniferous in age. Pre-Variscan rocks are affected by Sardic (Ordovician), Variscan, and Alpine deformational events and record Cadomian, Ordovician, and Carboniferous magmatic activity together with Variscan regional metamorphism (Casas, 2010; Guitard, 1970; Muñoz, 1992a; Navidad et al., 2018; Padel et al., 2018a; Pereira et al., 2014; Santanach, 1972b; Zwart, 1979).

In La Molina area (southern slope of the Canigó massif; Fig. 1), the Upper Ordovician (Sardic) Unconformity (Santanach, 1972a) splits the pre-Silurian sequence into underlying Cambrian-Ordovician and overlying Upper Ordovician successions, giving rise to a $\sim 20$ m.y. gap (Margalef et al., 2016) (Fig. 2). The Cambro-Ordovician succession is represented by the uppermost part of the Jujols Schists Series (Cavet, 1957), now referred to as the Serdinya Formation (Padel et al., 2018b) within the Jujols Group (Laumonier, 1988). It consists of a rhythmic alternation of sandstone and shale layers of millimetric to centimetric thickness. Late Cambrian (Furongian) to Early Ordovician (Tremadocian) acritarch-based age was established by Casas and Palacios (2012) in its uppermost

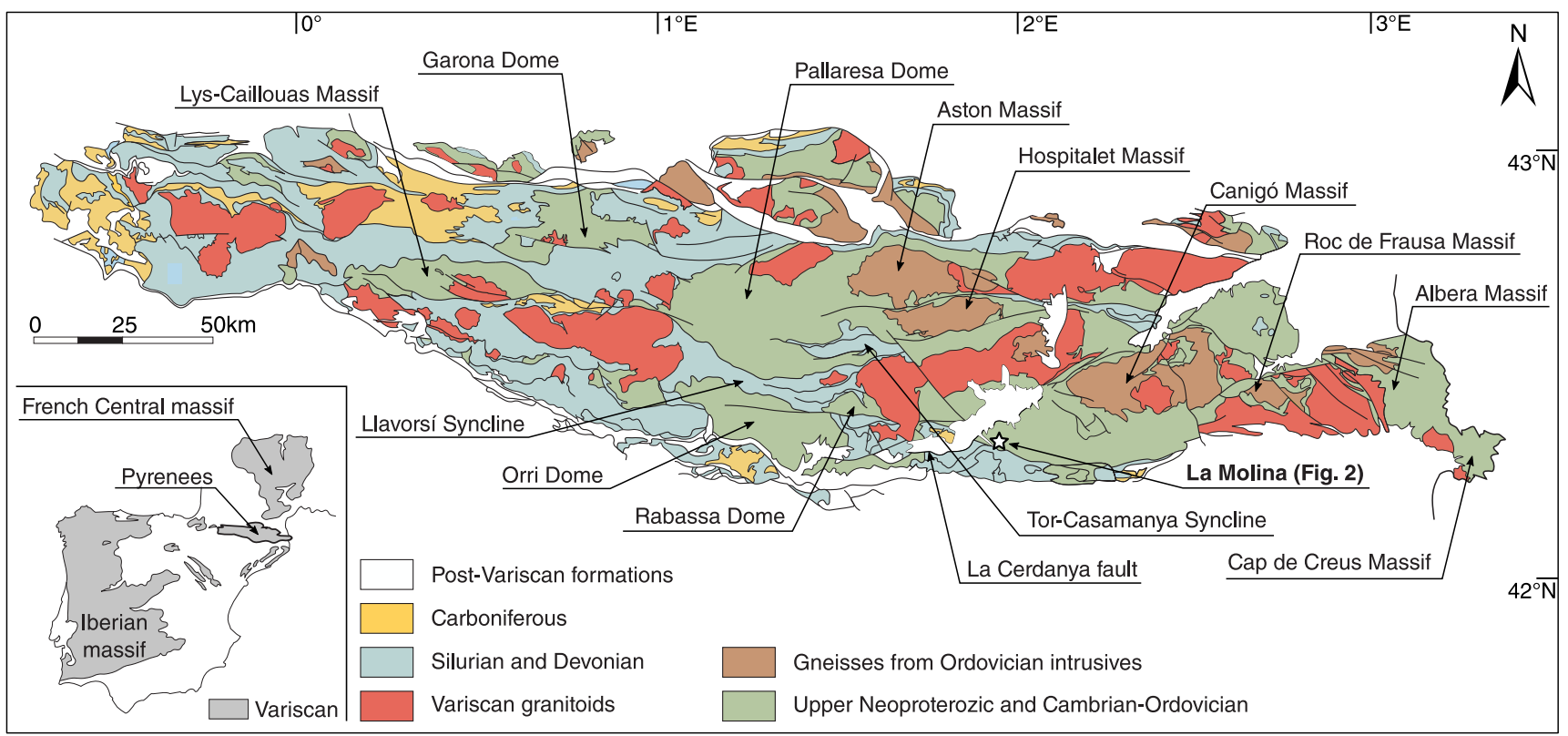

FIGURE 1. Geological sketch of the pre-Variscan rocks in the Pyrenees showing the location of the study area. 


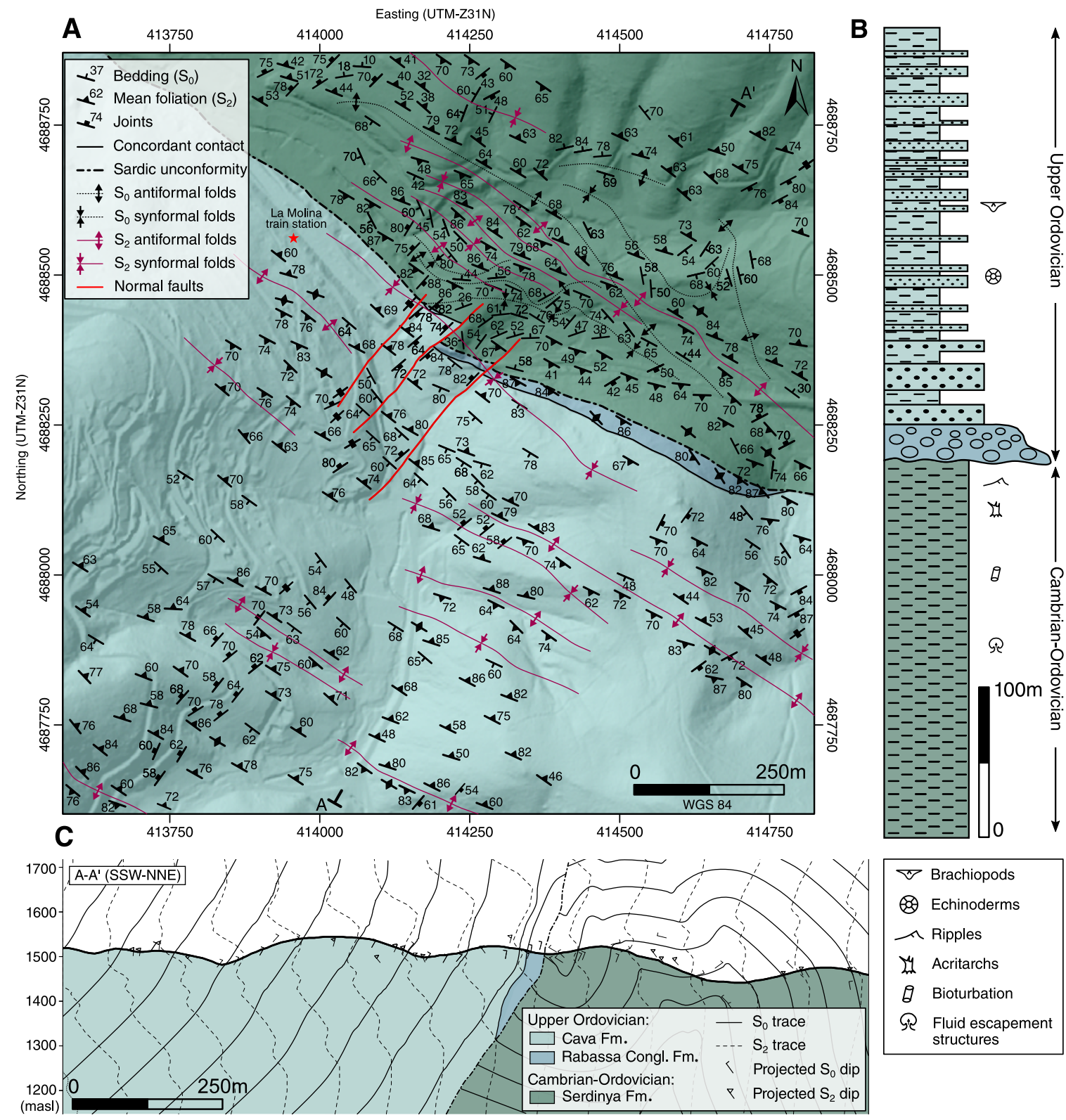

FIGURE 2. A) Detailed geological map of the study area. Location shown in Figure 1. B) Stratigraphic log of Cambrian-Ordovician and Upper Ordovician successions. C) Geological cross-section through the study area.

part, whilst a maximum depositional age of ca. $475 \mathrm{Ma}$ (Floian) was proposed by Margalef et al. (2016) on the basis of the youngest detrital zircon population.

The overlying Upper Ordovician succession (Cavet, 1957; Hartevelt, 1970) forms a broad fining-upward siliciclastic package with some limestone key levels, displaying significant (100-1,000m) thickness variations. This succession was originally defined by Hartevelt (1970), who described five formations. These are, from base to top, the Rabassa Conglomerate, Cava, Estana, Ansobell, and Bar Quartzite formations. In the study area only the Rabassa Conglomerate and Cava formations crop out.
The Rabassa Conglomerate Fm. is made up of red-purple matrix-supported unfossiliferous polymictic conglomerates composed of surrounding slate and quartzite heterometric $(2-20 \mathrm{~cm})$ clasts and its age has been established as Sandbian-Early Katian (former Caradoc) by Hartevelt (1970). In the study area, the Rabassa conglomerates form discontinuous lenses up to $60 \mathrm{~m}$ thick. These massiveto-channelised sets are interpreted as alluvial-to-fluvial deposits (Hartevelt, 1970). The overlying Cava Fm. is 100 $800 \mathrm{~m}$ thick and covers either the Serdinya or the Rabassa Conglomerate formations. It is made up of feldspathic conglomerates and sandstones in the lower part, showing a characteristic green-purple colour, grading upward into 
variegated shales and fine-grained sandstones, with strongly burrowed quartzites in the uppermost part (Belaustegui et al., 2016). On the basis of abundant brachiopods, bryozoans and echinoderms concentrated in fine-grained sandstones of the middle part of the formation, Gil-Peña et al. (2004) attributed a Katian (former Late Caradoc to Early Asghill) age to this formation.

The Cambrian-Ordovician succession is affected by a pre-Variscan (Middle Ordovician?) deformation (Casas, 2010; Casas et al., 2012; Santanach, 1972a) that gave rise to the formation of the Sardic Unconformity. This unconformity has also been recognised in other Pyrenean massifs (i.e. Lys-Caillouas area, Den Brok, 1989; Kriegsman et al., 1989; Garona Dome, García-Sansegundo and Alonso, 1989; García-Sansegundo et al., 2004 or the La Cerdanya area, Casas and Fernández, 2007; Puddu et al., 2019). The existence of this intra-Ordovician unconformity was first established in other NW Gondwana domains such as in Sardinia (Teichmuller, 1931), where it separates the Cambrian-Ordovician from the Upper Ordovician successions (Pillola et al., 2008), although its origin and meaning are still under debate (i.e. Cocco and Funedda, 2019; Pasci et al., 2008). As a result, the large-scale geodynamic processes that led to its formation have been subject to several interpretations (see a review in Álvaro et al., 2018). Moreover, the pre-Sardic succession, the Sardic Unconformity and the lowermost part of the post-Sardic succession are cut and offset by several Late Ordovician NNE-SSW-trending synsedimentary extensional faults, which caused variations in the thickness (from a few metres up to $100 \mathrm{~m}$ ) of the lower part of the Upper Ordovician succession (Casas, 2010; Puddu et al., 2019).

A penetrative cleavage parallel to the axial plane of folds is recognisable in both the pre- and post-Sardic successions. Classically, a Variscan age has been attributed to this folding episode (Casas, 2010; Casas et al., 2012; Santanach, 1972b), although the absence of post-Variscan deposits in the study area renders this attribution speculative. This cleavage can be correlated with the pervasive cleavage linked to the east-west trending folds that is the main deformation mesostructure in the Pallaresa, Rabassa, and Orri domes and in the Tor-Casamanya and Llavorsí synclines (Clariana and García-Sansegundo, 2009; Margalef and Casas, 2016; Poblet, 1991; Speksnijder, 1986).

During Alpine deformation the pre- and post-Sardic successions were part of the Rialp-Canigó unit, which is the lowermost Alpine unit including pre-Variscan basement rocks in the Pyrenees (Muñoz, 1992a). This author distinguished three main Alpine thrust sheets, from bottom to top: the Rialp-(Canigó), Orri-(Cadí) and Pedraforca(Nogueres), which form an antiformal stack with their basal thrusts north-dipping on the northern side of the chain, subhorizontal in the central part, and south-dipping at the southern contact with the Mesozoic-Cenozoic cover. Transverse (N-S-trending) southward displacement related to these Alpine thrust sheets is about $150-160 \mathrm{~km}$ (Muñoz, 1992a), so the original Palaeozoic basin should be located northward from present-day arrangement, being double the width of what is preserved today. The Rialp(Canigó) unit is the one originally located further south. Moreover, the Alpine deformation gave rise to important horizontal axes rotation, up to $110^{\circ}$, related to thrust sheet emplacement and antiformal stack development (Muñoz, 1992a). In contrast, Alpine metamorphism is absent and Alpine internal deformation has not been described in the pre-Variscan rocks. As a result, the original characteristics of the pre-Variscan rocks may be confidently reconstructed in the Pyrenees, although their original position must have been located further north. Finally, the La Cerdanya Neogene normal fault separates the study area (in the footwall) from the rest of the Cambrian-Ordovician and Upper Ordovician outcrops located further north (in the hanging wall) (Fig. 1).

In the Eastern Pyrenees, besides a number of metric veins spread throughout the Palaeozoic basement, discontinuous kilometric veins with metric to hectometric width massive aligned milky quartz bodies are also known. These larger veins cut metasedimentary sequences, orthogneiss and granitoids, and are crosscut by other very fine-grained quartz micro-veins, some with a few phyllosilicates and calcite. Host rock fragments in the veins are common near their boundary. Examples of these veins, from west to east, are the WNW-ESE Esquerdes de Rojà vein in the Canigó massif (Ayora and Casas, 1983), the W-E to NW-SE quartz veins of Roc de Frausa massif (Liesa, 1988), and the NW-SE Roses-Palau sections in the Cap de Creus massif (Fonseca et al., 2015).

In the study area, quartz veins with centimetric thickness and metric lengths crop out. Recently, their possible relationship with the Sardic events has been suggested by Casas et al. (2019) and Puddu et al. (2019), pointing out that the quartz veins encased in the uppermost part of the Jujols Group are subparallel to the trace of the extensional faults, and that they might have served as source of quartz clasts that form the Rabassa Conglomerate Fm. However, the petrography, structure, distribution, and formation conditions of these veins have not yet been described.

\section{METHODS}

The geological map and cross-section from La Molina area were generated using 3D-software MOVE® from the collected field data. The data corresponding to bedding, mean cleavage, bedding/cleavage intersection 
lineation, fold axes, joint sets, normal faults, and two generations of quartz veins, have been plotted in equal-area lower-hemisphere stereographic projections to carry out a classic structural analysis. Spatial distribution throughout the study area of quartz veins was obtained from quantifying the number of each vein family $(>0.5 \mathrm{~cm}$ thick) in visible outcropping square metre outcrops in the area. Altogether, 299 evenlydistributed outcrops were plotted using a Geographical Information System (GIS) and interpolated using the natural neighbour method. To interpolate a value, this algorithm finds the closest subset of input data to a query point, applying weights to the data based on proportionate areas (Sibson, 1981).

The petrographic study of 27 thin sections from samples of Cambrian-Ordovician and Upper Ordovician rocks and quartz veins was carried out with special emphasis on the texture, microstructure, and vein-rock relationship. Muscovites and chlorites were analysed in a JEOL JXA-8230 Electron Probe Microanalyzer (EPMA) at Centres Científics i Tecnològics of the Universitat de Barcelona (CCiTUB). The EPMA was operated using an excitation potential of $20 \mathrm{kV}$ and a beam diameter of $1 \mu \mathrm{m}$. Peak counting times for each analysed element was 10 s with the exception of $\mathrm{Na}$, where 20 s was used. Back measurements were made at $50 \%$ peak counting time on each side of the analysed peaks. Three semi-empirical geothermometers (Bourdelle et al., 2013; Inoue et al.,
2018; Lanari et al., 2014) were used via the spreadsheet from Verdecchia et al. (2019) to estimate vein formation temperatures. Calculations were applied to analysed chlorites without smectite or vermiculite interstratified layers $(\mathrm{Na}+\mathrm{Ca}+\mathrm{K}<0.1$ atoms per formula unit, a.p.f.u.) and octahedral sites below 5.95a.p.f.u., according to Bourdelle and Cathalineau (2015) and Vidal et al. (2016) under the premise that analyses with very low amounts of octahedral vacancies produce erratic temperature estimations.

Fluid inclusion petrography and microthermometric measurements were performed on $250 \mu \mathrm{m}$ thick double-polished sections from two quartz vein generations. Data was obtained on a Linkam THMSG 600 heating-freezing stage at the Department de Mineralogia, Petrologia i Geologia Aplicada of the Universitat de Barcelona. The stage was calibrated with fluid inclusions of pure $\mathrm{CO}_{2}$ and distilled water. The measurement precision was $\pm 0.1^{\circ} \mathrm{C}$ below $0^{\circ} \mathrm{C}$ and $\pm 2{ }^{\circ} \mathrm{C}$ for the homogenisation temperatures. The FLUIDS package from Baker (2003) was used to obtain the trapped-fluid properties. Salinity of fluid inclusions, reported in equivalent mass $\% \mathrm{NaCl}$, was calculated using Bodnar's (1993) equation in BULK software. The corresponding isochore was calculated from the obtained density and molar volume through the state equations of Bodnar and Vityk (1994) and Knight and Bodnar (1989) in ISOC software.
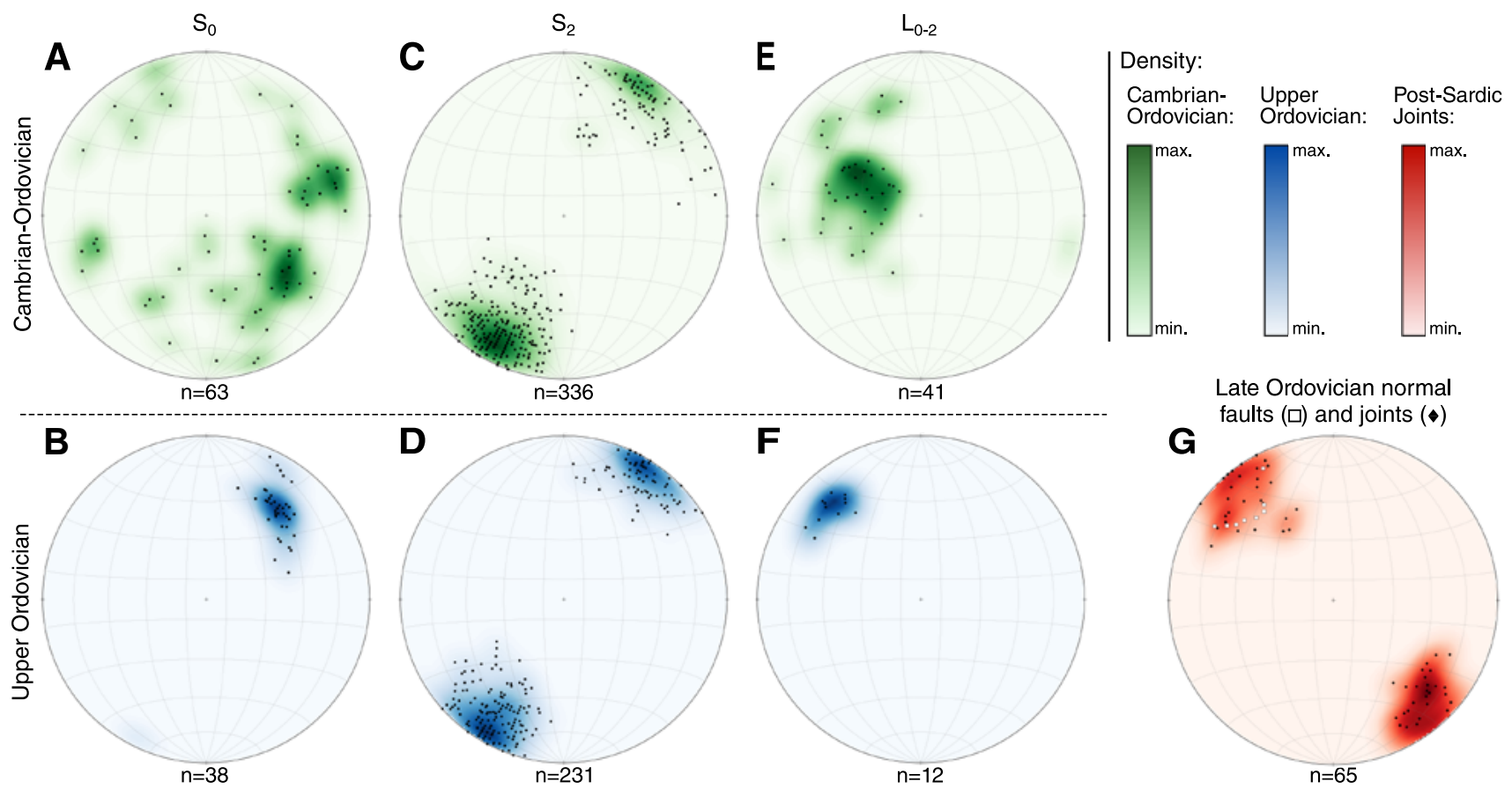

FIGURE 3. Equal-area lower hemisphere stereoplots of bedding $\left(S_{0}\right)$, cleavage $\left(S_{2}\right)$ and intersection lineation $\left(L_{0-2}\right)$, $A$, $C$, E) from the CambrianOrdovician and B, D, F) Upper Ordovician successions. G) Late Ordovician normal faults and joints. $n$ indicates the number of measurements. 


\section{STRUCTURE}

A detailed geological map of La Molina area (1:5,000 scale) and a stratigraphic log of the Cambrian-Ordovician and Upper Ordovician successions are shown in Figure 2A, B. The study area is in the WNW-ESE trending verticalto-subvertical southern flank of the Canigó antiform, truncated in the south by the Alpine Ribes-Camprodon thrust (Muñoz, 1992b) that separates the Canigó antiform from a southwards located synform where Silurian, Devonian, and pre-Variscan Carboniferous successions crop out extensively (Figs. 1; 2C).

The most visible mesostructures of the CambrianOrdovician and Upper Ordovician rocks are the bedding surfaces $\left(\mathrm{S}_{0}\right)$, which exhibit different attitude in each succession. In the Cambrian-Ordovician succession, $\mathrm{S}_{0}$ values display a marked dispersion with dips ranging from subvertical to subhorizontal (Fig. 3A). In contrast, the Upper Ordovician $\mathrm{S}_{0}$ bedding surfaces are southwards dipping and exhibit a more regular NW-SE trend (Fig. 3B).

A rough slaty cleavage $\left(\mathrm{S}_{1}\right)$ is only observed at microscopic scale in the Cambrian-Ordovician rocks. Other deformational mesostructures or folds associated with this cleavage have not been identified.

A roughly NNE-dipping $S_{2}$ crenulation cleavage parallel to $\mathrm{D}_{2}$ folds axial planes and affecting both CambrianOrdovician and Upper Ordovician rocks is the most pervasive deformation structure recognised at micro and meso scales (Fig. 3C, D). As with the $\mathrm{S}_{2}$ cleavage, $\mathrm{D}_{2}$ fold axial surfaces display a moderate-to-subvertical dip $\left(45^{\circ}-90^{\circ}\right)$ towards the NNE. The $\mathrm{D}_{2}$ folds are $\mathrm{SW}$ verging, open to tight, generally metric to hectometric in size. $\mathrm{D}_{2}$ fold axes $\left(\mathrm{L}_{2}\right)$ exhibit different orientations in the pre- and post-Sardic rocks (Fig. 3E, F). In the post-Sardic (Upper Ordovician) succession, $\mathrm{L}_{2}$ axes and $\mathrm{L}_{0-2}$ intersection lineations are clustered forming a maximum with a low plunge to the NW $\left(15 / 320^{\circ}\right)$ (Fig. $3 \mathrm{~F})$. According to the bedding/cleavage relationship, the study area constitutes the southern limb of a south-facing first-order $\mathrm{D}_{2}$ fold, oriented NW-SE (Fig. 2C). In contrast, the minor $\mathrm{L}_{2}$ axes and $\mathrm{L}_{0-2}$ intersection lineations in the pre-Sardic (Cambrian-Ordovician) rocks display a wide range of orientations and dispersions. $\mathrm{L}_{0-2}$ plunge ranges from sub-vertical to sub-horizontal (Fig. 3E) and no simple distribution pattern may be deduced from the map analysis (Fig. 2A). If $\mathrm{L}_{0-2}$ and $\mathrm{L}_{2}$ of the Cambrian-Ordovician rocks are plotted together, they are mainly distributed along a great circle coincident with the $S_{2}$ average plane, although a wide maximum oriented ca. $50 / 295^{\circ}$ can be envisaged (Fig. 3E). This pattern displayed by $\mathrm{D}_{2}$ linear elements in the Cambrian-Ordovician sequence may be explained if $D_{2}$ folds developed over initially non-horizontal surfaces, that is if pre-existing folds control the geometry of $\mathrm{D}_{2}$ mesoscale folds (e.g. Mey, 1967, p.194; Ramsay, 1967, p.539; Turner and Weiss, 1963, p.130).

The existence of previous folds may also explain the arrangement of $\mathrm{S}_{0}$ bedding surfaces at outcrop and map scales in the Cambrian-Ordovician succession. It should be noted that there is no evidence of axial planar cleavage development or other mesostructures related to these pre- $\mathrm{D}_{2}$ folds.

Extensional synsedimentary faults and several NE-SWtrending joints (Figs. 2A; 3G), have also been recognised in the study area. The moderate-to-strongly SE-dipping extensional faults cut and offset the Upper Ordovician Unconformity, resulting in up to $60 \mathrm{~m}$ thickness variations in the lowermost part of the Upper Ordovician succession. Otherwise, joints display a moderate-to-subvertical dip towards the SE or NW (Fig. 3G), occurring mostly towards the SW continuation of the extensional fault's trace (Fig. $2 \mathrm{~A})$.

\section{QUARTZ VEINS CHARACTERISTICS AND DISTRIBUTION}

The small extension together with accessible outcrops in the study area has allowed detailed characterisation of the quartz veins. Two generations (V1 and V2) have been deciphered according to their spatial distribution patterns throughout the study area and their relationships to the $S_{2}$ cleavage (Fig. 4). The number of veins of each generation per $\mathrm{m}^{2}\left(\mathrm{~N}_{\mathrm{V} 1(>0.5 \mathrm{~cm})} / \mathrm{m}^{2}\right.$ and $\left.\mathrm{N}_{\mathrm{V} 2}(>0.5 \mathrm{~cm}) / \mathrm{m}^{2}\right)$ determined for 299 outcrops from both Cambrian-Ordovician and Upper Ordovician successions is available in the Appendix, Table I.

Distribution patterns reveal that V1 veins are mostly arranged around the Upper Ordovician Unconformity and the synsedimentary normal faults, with no preferred orientations (Fig. 4A). V1 veins are deformed by $\mathrm{D}_{2}$ folds and crosscut by the $\mathrm{S}_{2}$ cleavage (Fig. 4A). Otherwise, V2 veins are distributed more regularly and with higher density than V1 veins (Fig. 4B), with no clustering throughout the study area and showing a preferential orientation parallel to the $S_{2}$ cleavage. This distribution and its relationships suggest that the V1 vein formation should be previous to the $\mathrm{D}_{2}$ folding episode. On the other hand, otherwise, the parallelism relationship of the V2 veins with the $S_{2}$ cleavage (Figs. 3C, D; 4B) suggests a post- $\mathrm{S}_{2}$ formation for this vein generation, the age of which will be discussed below.

\section{PETROGRAPHY}

Cambrian-Ordovician shales (Fig. 5A-C) and Upper Ordovician conglomerates and feldspathic sandstones 


\section{A}
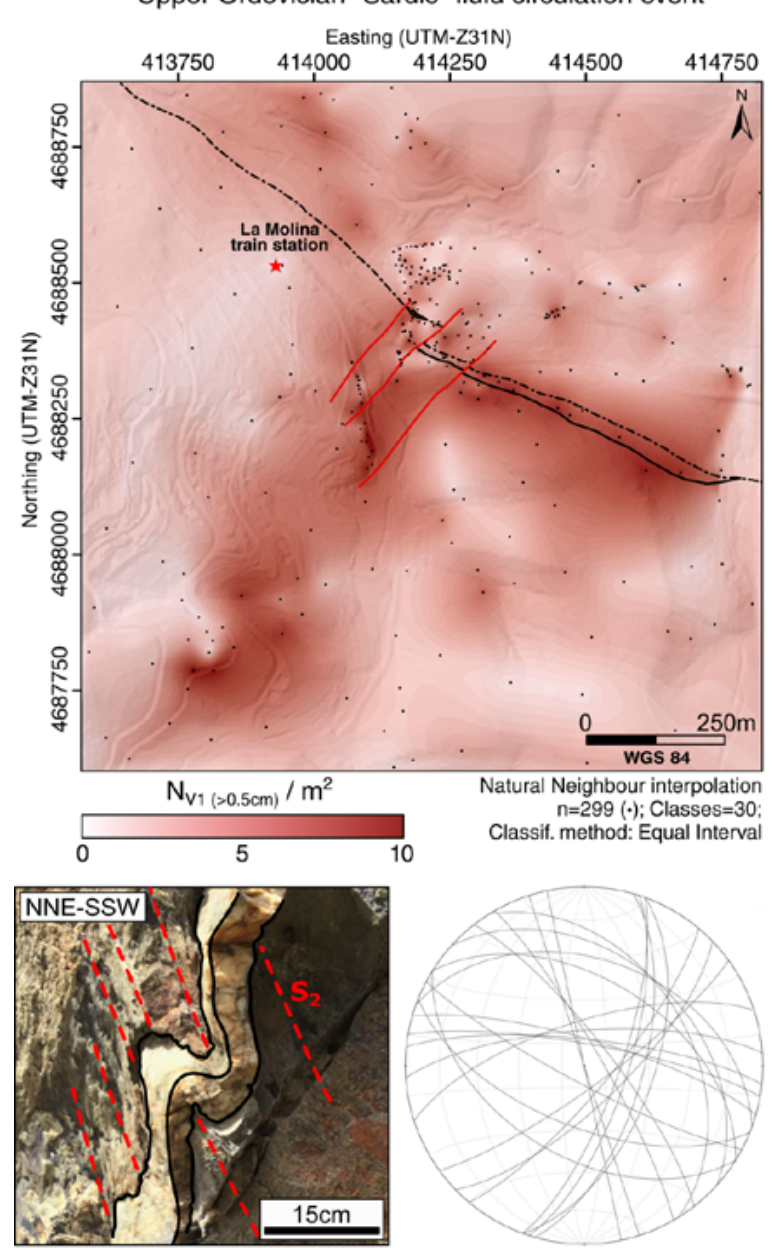

$\mathrm{V} 1$

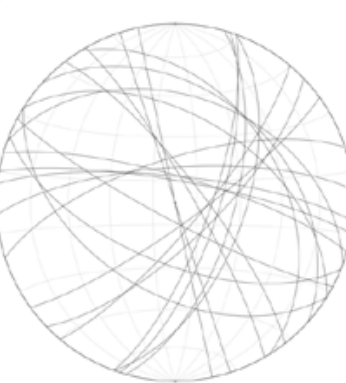

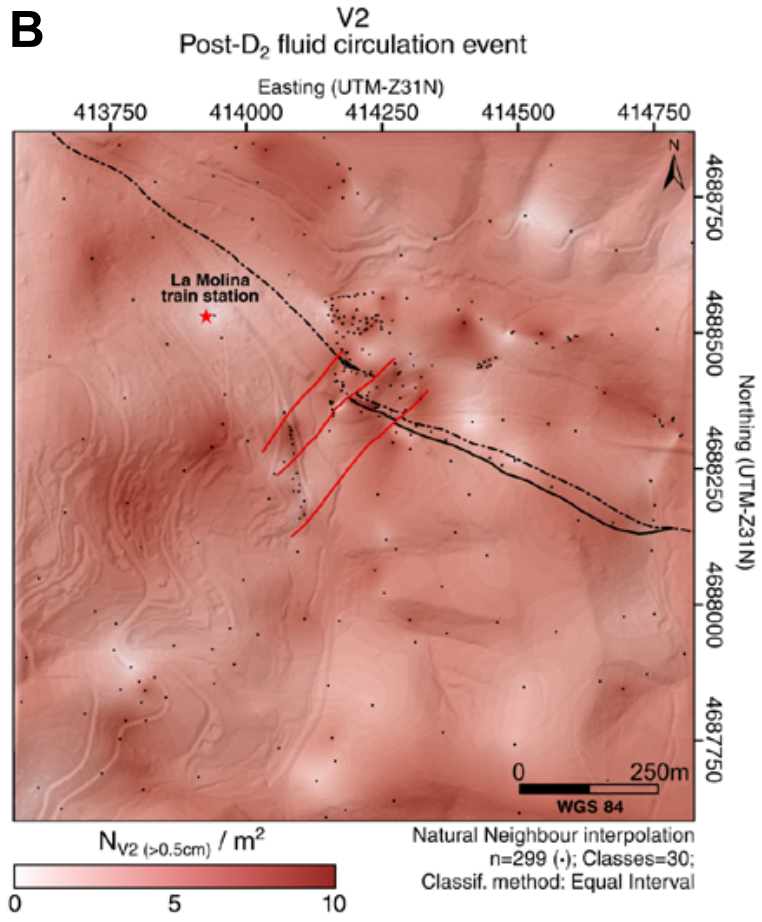

B
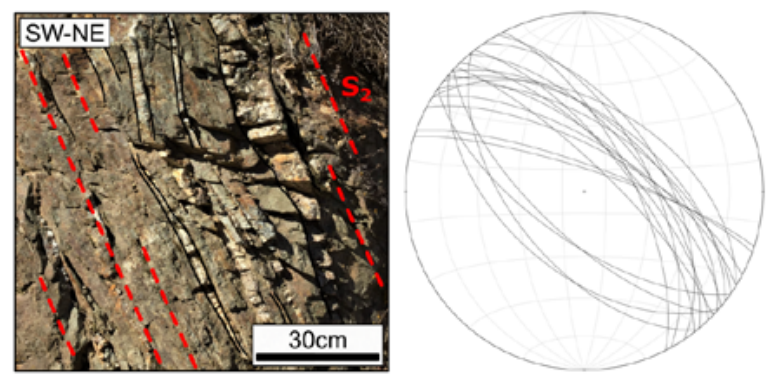

FIGURE 4. Distribution patterns, arrangement and structural relations with the $S_{2}$ cleavage of the A) V1 and B) V2 veins. Note the spatial relations between the V1 veins and the Sardic Unconformity and extensional faults from Figure $2 \mathrm{~A}$. $\mathrm{n}$ indicates the number of outcrops where $\mathrm{N}_{\mathrm{v} 1}(>0.5 \mathrm{~cm}) / \mathrm{m}^{2}$ and $\mathrm{N}_{\mathrm{v} 2(>0.5 \mathrm{~cm})} / \mathrm{m}^{2}$ have been characterised. Data available in the Appendix, Table I.

(Fig. 5D, E) exhibit clear microstructure differences. Cambrian-Ordovician shales, in areas with high amounts of quartz veins, show micrometric to millimetric width bedding surfaces defined by compositionally different bands (Fig. 5A, B). The thinnest bands $(60 \mu \mathrm{m}-0.5 \mathrm{~mm})$ are rich $(>90 \%)$ in phyllosilicates with chlorite and muscovite $(<20 \mu \mathrm{m})$ and poor $(<10 \%)$ in quartz, representing a Localised Volume Reduction (LVR) interpreted as beddingparallel compaction bands (e.g. Aydin et al., 2006; Fossen et al., 2007) (Fig. 5B). Otherwise, the thickest bands (0.5$1.75 \mathrm{~mm}$ ) are mostly formed by quartz (>95\%) (Fig. 5A). In both cases quartz grains show a granoblastic texture with intracrystalline deformation and sutured boundaries, indicating recrystallisation processes. Eventually, the rough $S_{1}$ is transposed by the $S_{2}$ main cleavage (Fig. 5C). $S_{2}$ is anastomosed, well-developed, and defined by the preferred orientation of phyllosilicates in the thinness bands, surrounding in some cases larger euhedral-to-subhedral chlorite crystals $(<100 \mu \mathrm{m})$ (Fig. 5C).
Upper Ordovician Rabassa conglomerates are constituted by rounded to sub-rounded shale, quartzite and monomineralic quartz clasts supported in a quartz $(90 \%)+$ phyllosilicates $(5 \%) \pm$ opaque minerals $(5 \%)$ matrix (Fig. $5 \mathrm{D})$. Matrix quartz grains $(40-100 \mu \mathrm{m})$ show a granoblastic texture with sutured boundaries. Shale clasts, $1-4 \mathrm{~mm}$ in size, are interpreted as Serdinya Fm. sourced. Quartzite clasts $(0.01-2 \mathrm{~cm})$ are eventually elongated without any preferential orientation and include chlorite-bearing stylolites. Monomineralic polycrystalline quartz clasts $(0.3-$ $3 \mathrm{~mm}$ ) are elongated in a preferential orientation and show characteristic textural and microstructural relationships with quartz veins (see below this section). $S_{0}$ is represented by the alignment of opaque matrix minerals, eventually deformed by open folds with axial surfaces parallel to $S_{2}$. The preferential orientation of matrix phyllosilicates and the elongation direction of monomineralic quartz define the $S_{2}$ surfaces that are the only visible surfaces in the matrix since they surround all the clasts (Fig. 5D). 

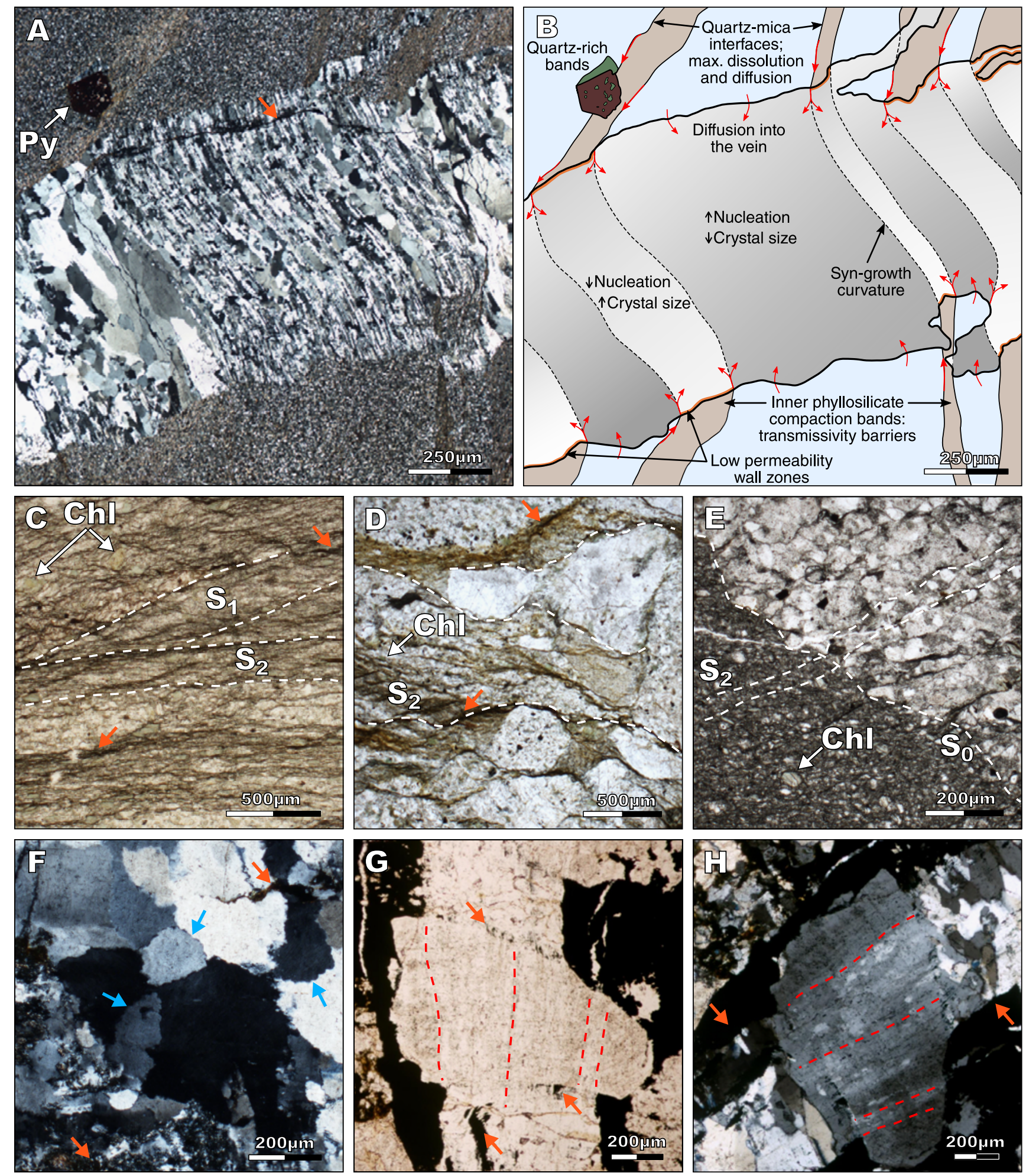

FIGURE 5. Microphotographs of Cambrian-Ordovician and Upper Ordovician rocks: A) V1 vein hosted in the Serdinya Formation with in-vein stripes related to the host rock phyllosilicate compaction bands (Cross-polarised light, XPL); B) interpretation of (A) (see text for further explanation); C) euhedral chlorite (Chl) crystals growing coevally with $S_{2}$, the latter transposing the $S_{1}$ cleavage (Plane-polarised light, $P P L$ ); D) $S_{2}$ cleavage surrounding monomineralic quartz and quartzite clasts ; Rabassa Conglomerate Formation (PPL); E) grain-size variations $\left(\mathrm{S}_{0}\right)$ and their relationship with $\mathrm{S}_{2}$ cleavage; Cava Formation (PPL); F) sutured boundaries (blue arrows) from a V2 blocky vein; Cava Formation (XPL); G) complex relationships between monomineralic quartz clast from the Rabassa Conglomerate Formation and a transgranular V1 vein in PPL; and H) XPL (see text for further explanation). Orange arrows indicate Fe-oxide locations. Red arrows indicate the silica dissolution and diffusion pathways. Double red arrows indicate the maximum silica diffusion into the vein. Abbreviations: $\mathrm{Py}=$ pyrite; $\mathrm{Chl}=$ chlorite. 
The Cava Fm. conglomerates are composed of clasts of the same type and origin as those described for the Rabassa Conglomerate Fm. clasts are homometric (generally $1-2 \mathrm{~mm}$ ) and are supported in a quartzo-feldsphatic matrix that also includes tourmaline, zircon, and apatite crystals $(10-30 \mu \mathrm{m}) . \mathrm{S}_{0}$ is well-defined by matrix grain-size variations (from $10-60 \mu \mathrm{m}$ to $0.25-0.5 \mathrm{~mm}$; Fig. $5 \mathrm{E}$ ) and by opaque mineral alignment, whereas $S_{2}$ is depicted by the preferential orientation of phyllosilicates, monomineralic polycrystalline quartz and shale clasts. Some chlorite grains $(0.02-0.25 \mathrm{~mm}$ in size) unrelated to matrix grainsize variations (Fig. 5E) appear growing coevally to $S_{2}$. They contain layers showing optical characteristics of biotite, which are also compatible with stilpnomelane and with small-scale interleaving of chlorite with other phyllosilicates (Franceschelli et al., 1986; Mellini et al., 1991).

Host-rocks described above and veins (see below this section) have up to $20 \%$ of Fe oxides, which permeate $\mathrm{S}_{1}$ and $\mathrm{S}_{2}$ cleavages, stylolites, clasts boundaries, and quartz vein walls (Fig. 5A, C-H). V1 walls are apparently more permeated by Fe oxides than V2 walls. Euhedral to subhedral pyrite crystals $(30 \mu \mathrm{m}-0.8 \mathrm{~mm})$ unlinked to grain-size variations depict quartz and chlorite pressure fringes (Fig. 5A, B) and are also present in both Rabassa Conglomerate and Cava formations.

For the petrographic characterisation, $1-2 \mathrm{~cm}$ thick veins from both (V1 and V2) generations hosted in CambrianOrdovician and Upper Ordovician successions were selected in order to identify possible differences between them. The texture of both V1 and V2 quartz veins varies from blocky to elongated-blocky without any preferential direction. Blocky veins (Fig. 5F) are generally narrow $(0.2-4 \mathrm{~mm})$, containing homometric grains $(50 \mu \mathrm{m}-0.3 \mathrm{~mm})$ with sutured edges. Elongated blocky veins (Fig. 5A, B) are wider $(1-15 \mathrm{~mm})$ and quartz crystals have a length/width ratio on the order of 10 . The crystals' long axes are aligned perpendicularly to the vein walls, having a large quantity of smaller crystals on the vein-margins and a reduced quantity of larger crystals towards the veins centres. A concaveconvex curvature along the long axis of crystals in V1 veins eventually develops (Fig. 5A, B), indicating syntaxial growth morphology (Bons, 2000; Durney and Ramsay, 1973; Ramsay, 1980).

Properties of vein-filling quartz crystals from CambrianOrdovician-hosted V1 veins are variable. This is because quartz-rich and phyllosilicate-rich bands from the Serdinya Fm. match with quantity and grain-size variations inside the veins (Fig. 5A): phyllosilicate-rich compaction bands result in stripes within the veins having larger crystals, whilst quartz-rich bands result in stripes with a higher quantity of smaller crystals. This microstructural variation inside veins has not been recognised in the Upper Ordovicianhosted V1 veins, probably due to the lack of phyllosilicate compaction bands in this succession. Furthermore, complex relationships between $\mathrm{V} 1$ veins and monomineralic quartz clasts from the Rabassa Conglomerate Fm. have been identified (Fig. 5G, H). Limits between both show a "net" surface in plane-polarised light (PPL) defined by Fe oxides (Fig. 5G). Otherwise, in cross-polarised light (XPL), the elongation of vein crystals shows different properties when the vein crosses the matrix components or the monomineralic quartz clasts. As the vein crosses a quartz clast, the crystals exhibit elongation parallel to the vein wall, becoming perpendicular to it at the end of the clast when the vein becomes matrix-shrouded again (Fig. $5 \mathrm{H})$.

\section{PHYLLOSILICATES CHEMISTRY AND CHLORITE GEOTHERMOMETRY}

Phyllosilicates, white mica and chlorite, from host rocks and veins (Fig. 6) have been chemically characterised by electron microprobe (see Appendix, Tables II, III for compositions and calculated structural formulae on the $14 \mathrm{O}$ basis, with the total $\mathrm{Fe}$ expressed as $\mathrm{FeO}$ ). White micas (Fig. 6A, B) are present in host rocks, with no textural differences among Cambrian-Ordovician and Upper Ordovician successions. They occur as tabular or flaky-shaped crystals $<20 \mu \mathrm{m}$ in size and are aligned parallel to $\mathrm{S}_{2}$ planes, or more often as white mica-chlorite stacks (intergrowth packets) $(1-8 \mu \mathrm{m})$ (Fig. 6B). Nevertheless, Cambrian-Ordovician white micas (Equation 1) show significantly higher amounts of $\mathrm{K}, \mathrm{Fe}^{2+}, \mathrm{Mg}$ a.p.f.u. and lower $\mathrm{Al}^{(\mathrm{VI})}$ a.p.f.u. than the Upper Ordovician succession (Equation 2).

(1) $\mathrm{K}_{0,79 \pm 0,13}^{+} \mathrm{Al}^{3+}{ }_{1,70 \pm 0,09} \mathrm{Fe}^{2+}{ }_{0,23 \pm 0,08} \mathrm{Mg}^{2+}{ }_{0,16 \pm 0,05}\left[\mathrm{Al}^{3+}{ }_{0,88 \pm 0,07}\right.$ $\left.\mathrm{Si}^{4+}{ }_{3,12 \pm 0,07} \mathrm{O}_{10}\right](\mathrm{OH})_{2}$

(2) $\mathrm{K}_{0,72 \pm 0,04}^{+} \mathrm{Al}^{3+}{ }_{1,89 \pm 0,04} \mathrm{Fe}_{0,14 \pm 0,05}^{2+} \mathrm{Mg}_{0,05 \pm 0,00}^{2+}\left[\mathrm{Al}_{0,84 \pm 0,01}^{3+}\right.$ $\left.\mathrm{Si}^{4+}{ }_{3,16 \pm 0,01} \mathrm{O}_{10}\right](\mathrm{OH})_{2}$

Chlorites are present in host rocks (Fig. 6A, B, C), in the walls of V1 veins (Fig. 6D, E) and in the centre and walls of V2 veins (Fig. 6F, G, H). All chlorites are classified as ripidolites according to Hey (1954) chamosites according to the Association Internationale pour l'Étude des Argiles (AIPEA) nomenclature (Fig. 7A). The chlorites that are hosted either in pre- or postSardic rocks occur as euhedral to subhedral greenish-brownish crystals, $50-150 \mu \mathrm{m}$ in size and eventually replaced along cleavage planes by iron-oxides (Fig. 6A, B). In some cases, flaky-shaped chlorites occur associated with stylolites in monomineralic polycrystalline quartz clasts of the Rabassa conglomerates (Fig. 6C). Pre-Sardic-hosted chlorites have higher $\mathrm{Mg}$ a.p.f.u. and lower $\mathrm{Fe}^{2+}$ a.p.f.u. (Equation 3, n=29) compared with those hosted in post-Sardic rocks (Equation 4, $\mathrm{n}=5$ ). Altogether they show a 

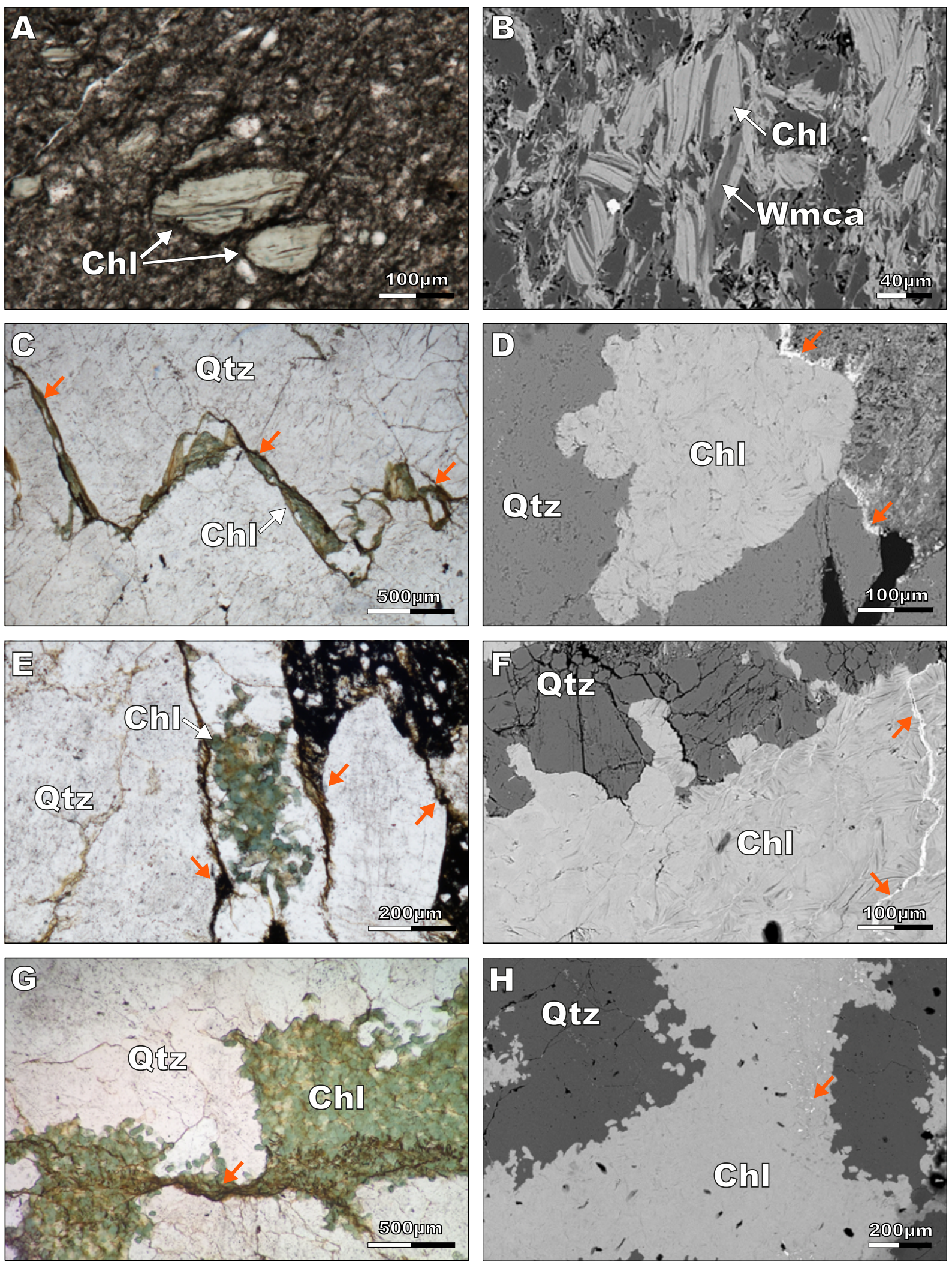

FIGURE 6. Plane-polarised light microphotographs ( $, C, E, G)$ and back-scattered electron images (B, D, F, H) of the analysed phyllosilicates: A) chlorite (Chl) growing coevally with $\mathrm{S}_{2}$ cleavage; Cava Formation; B) chlorite and white mica (Wmca) interstratification; Serdinya Formation; C) chlorite-bearing stylolite in a monomineralic quartz (Qtz) clast; Rabassa Conglomerate Formation; D) chlorite in a Upper Ordovician-hosted V2 vein margin; E) chlorite in a Upper Ordovician-hosted V1 vein margin; F) chlorite in a Cambrian-Ordovician-hosted V2 vein margin; G) and H) chlorite in a Upper Ordovician-hosted V2 vein centre. 

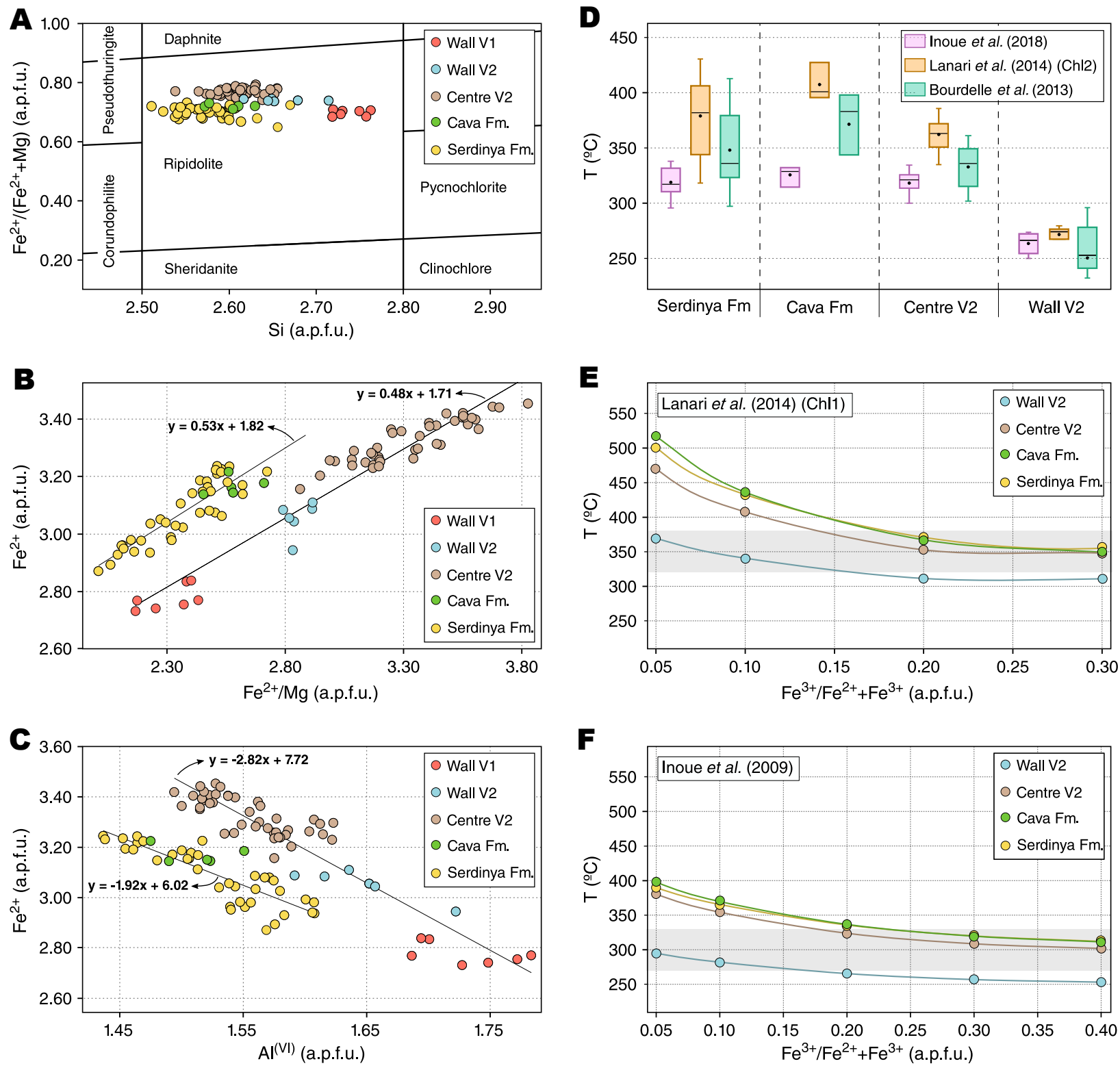

FIGURE 7. A) Si vs. FeT/FeT+Mg (after Hey, 1954), B) FeT/Mg vs. FeT, and C) Al(vl) vs. FeT diagrams of analysed chlorites. Note the two sub-parallel trends for vein- and rock-hosted chlorites in (B) and (C). D) Formation temperatures obtained from the three applied geothermometers for the V2 veins (wall and centre) and host rocks; for each dataset, coloured boxes are the standard deviations (first and third quartiles), while horizontal lines are the median, black points are the mean value and whiskers are the maximum and minimum values (95\% interval). E), F) T variations depending on the assumed $\mathrm{Fe}^{3+} / \mathrm{Fe}^{2+}+\mathrm{Fe}^{3+}$ content for the Lanari et al. (2014) (Chl1) and Inoue et al. (2009) geothermometers, respectively; shaded areas indicate the confidence interval between the V2 wall and V2 centre formation temperatures considering the typical errors $\left( \pm 30^{\circ} \mathrm{C}\right)$ of the methods.

positive correlation in an FeT/Mg vs. FeT diagram (Fig. 7B), and a negative correlation in an $\mathrm{Al}_{(\mathrm{VI})}$ vs. FeT diagram (Fig. 7C).

(3) $\left(\mathrm{Mg}^{2+}{ }_{1.30 \pm 0.06} \mathrm{Fe}^{2+}{ }_{3.09 \pm 0.11} \mathrm{Al}^{3+}{ }_{1.53 \pm 0.05} \square_{0.05 \pm 0.03}\right)\left[\left(\mathrm{Si}^{4+}{ }_{2.58 \pm 0.03}\right.\right.$ $\left.\left.\mathrm{Al}^{3+}{ }_{1.42 \pm 0.03}\right) \mathrm{O}_{10}\right](\mathrm{OH})_{8}$

(4) $\left(\mathrm{Mg}^{2+}{ }_{1.23 \pm 0.04} \mathrm{Fe}^{2+}{ }_{3.17 \pm 0.03} \mathrm{Al}^{3+}{ }_{1.51 \pm 0.03} \square_{0.05 \pm 0.02}\right)\left[\left(\mathrm{Si}^{4+}{ }_{2.60 \pm 0.02}\right.\right.$ $\left.\left.\mathrm{Al}^{3+}{ }_{1.40 \pm 0.02}\right) \mathrm{O}_{10}\right](\mathrm{OH})_{8}$

Chlorites located in V1 and V2 veins walls (Fig. 6D, E, F) occur as isolated euhedral crystals (100-200 $\mu \mathrm{m})$ or more often as aggregates $(0.1-0.4 \mathrm{~mm})$ of vermicular or chrysanthemum-shaped crystals $(20-60 \mu \mathrm{m})$ (Fig. 6D, E, F). Otherwise, chlorites located in V2 veins centre (Fig. $6 \mathrm{G}, \mathrm{H})$ only occur as aggregates $(0.2-2 \mathrm{~mm})$ of crystals $(40-150 \mu \mathrm{m})$. Chlorites in V1 walls (Equation 5, $\mathrm{n}=7$ ) have the highest amounts of $\mathrm{Si}$ and $\mathrm{Mg}$ a.p.f.u. and the lowest amounts of FeT a.p.f.u. Chlorites in V2 walls (Equation 6, $\mathrm{n}=6$ ) are compositionally between the chlorites in the V1 wall and in the V2 centre (Equation 7, n= 43), the latter having the highest $\mathrm{Fe}^{2+}$ a.p.f.u. and the lowest $\mathrm{Si}$ and $\mathrm{Mg}$ 
a.p.f.u. Altogether, vein-hosted chlorites display a positive correlation in FeT/Mg vs. FeT diagrams (Fig. 7B) and a negative correlation in $\mathrm{Al}^{(\mathrm{VI})}$ vs. FeT diagrams (Fig. 7C). Correlation lines have a similar slope for the vein-hosted and host-rock chlorites, although lines do not overlap due to the aforementioned compositional differences (Fig. $7 \mathrm{~B}, \mathrm{C})$. Furthermore, if the chlorite location (V2 wall vs. $\mathrm{V} 2$ centre) and vein-generation (V1 wall vs. V2 wall) are considered, three compositional groups in FeT, $\mathrm{Mg}$ and $\mathrm{Al}^{(\mathrm{VI})}$ a.p.f.u. diagrams are deciphered.

(5) $\left(\mathrm{Mg}^{2+}{ }_{1.20 \pm 0.05} \mathrm{Fe}^{2+}{ }_{2.78 \pm 0.04} \mathrm{Al}^{3+}{ }_{1.73 \pm 0.04} \square_{0.29 \pm 0.02}\right)\left[\left(\mathrm{Si}^{4+}{ }_{2.74 \pm 0.02}\right.\right.$ $\left.\left.\mathrm{Al}^{3+}{ }_{1.26 \pm 0.02}\right) \mathrm{O}_{10}\right](\mathrm{OH})_{8}$

(6) $\left(\mathrm{Mg}^{2+}{ }_{1.07 \pm 0.02} \mathrm{Fe}^{2+}{ }_{3.05 \pm 0.06} \mathrm{Al}^{3+}{ }_{1.65 \pm 0.04} \square_{0.22 \pm 0.04}\right)\left[\left(\mathrm{Si}^{4+}{ }_{2.66 \pm 0.03}\right.\right.$ $\left.\left.\mathrm{Al}^{3+}{ }_{1.34 \pm 0.03}\right) \mathrm{O}_{10}\right](\mathrm{OH})_{8}$

(7) $\left(\mathrm{Mg}^{2+}{ }_{1.00 \pm 0.05} \mathrm{Fe}^{2+}{ }_{3.32 \pm 0.08} \mathrm{Al}^{3+}{ }_{1.56 \pm 0.03} \square_{0.11 \pm 0.02}\right)\left[\left(\mathrm{Si}^{4+}{ }_{2.61 \pm 0.02}\right.\right.$ $\left.\left.\mathrm{Al}^{3+}{ }_{1.39 \pm 0.02}\right) \mathrm{O}_{10}\right](\mathrm{OH})_{8}$

Semi-empirical geothermometers (Bourdelle et al., 2013; Inoue et al., 2018; Lanari et al., 2014) were applied to rock- and vein-hosted chlorites. In the analyses, Fe total is expressed as $\mathrm{FeO}$, and $\mathrm{Fe}_{2} \mathrm{O}_{3}$ content is unknown. For the application of these geothermometers, the lack of $\mathrm{X}_{\mathrm{Fe}^{3+}}$ is not a hindrance due to combination of thermodynamic calculations with semi-empirical comparisons based on the Inoue et al. (2018) approach (Verdecchia et al., 2019). By this method, the estimation of $X_{\mathrm{Fe}^{3+}}$ is based on the comparison of formation temperatures estimated with semi-empirical thermometers that include or not the $\mathrm{Fe}^{3+}$. Bourdelle et al. (2013), Lanari et al. (2014) (Chl2) and Inoue et al. (2018) geothermometers are valid for formation conditions of $<350^{\circ} \mathrm{C}$ and $<4 \mathrm{kbar}, 100-500^{\circ} \mathrm{C}$ and $1-20 \mathrm{kbar}$ and $<400^{\circ} \mathrm{C}$, respectively. Furthermore, each geothermometer has restrictions that should be fulfilled by the analysed chlorites: for the application of the Bourdelle et al. (2013) geothermometer, the a.p.f.u. for Si should be between 2 and 4 vacancies $\left(\mathrm{Al}^{(\mathrm{VI})}-\mathrm{Al}^{(\mathrm{IV}) / 2}\right)>0.05$ a.p.f.u.; for the Lanari et al. (2014) (Chl2) geothermometer, the Si a.p.f.u. should be $<3$, vacancies $\left(\mathrm{Al}^{(\mathrm{VI})}-\mathrm{Al}^{(\mathrm{IV})}-\mathrm{Na}-\mathrm{K} / 2\right)>0.05$ a.p.f.u. and an estimated pressure value $(0.5 \mathrm{kbar}$ for $\mathrm{V} 1$ and $2 \mathrm{kbar}$ for V2 and host rock chlorites) is necessary; for the Inoue et al. (2018) geothermometer, vacancies $\left(6-\left(\mathrm{Fe}^{2+}+\mathrm{Mg}+\mathrm{A}^{\mathrm{VI}}\right)\right.$ should be $<1$ a.p.f.u. and $\mathrm{NaO}+\mathrm{K}_{2} \mathrm{O}+\mathrm{CaO}<0.5$ a.p.f.u.).

All chlorites used here as geothermometers are in agreement with the aforementioned premises. From the analyses plotted in Figure 7A, B, C, only those with the sum of octahedral sites below 0.95a.p.f.u. were used for the temperature estimations, so the analyses with low amounts $(<0.05)$ of octahedral vacancies have been discarded. Rock and V2 centre hosted chlorites show the maximum temperatures, being slightly higher those obtained from Cava Fm.-hosted ones (Fig. 7D; Table 1). Significantly different formation temperatures from vein-hosted chlorites were obtained for the three geothermometers, depending on the location and vein-generation (Fig. 7D; Table 1). According to all geothermometers applied, temperature increasing towards the vein centre is perceived from the V2 centre and V2 wall comparison, whilst significantly lower temperatures were obtained for the V1 wall (Fig. 7D; Table 1). As only wall-hosted chlorites have been identified in the V1 veins, it cannot be determined whether or not this difference in chlorite formation temperature dependent on vein location occurs for both vein types. Here, only the temperatures obtained from the $\mathrm{V} 2$ centre and rock hosted chlorites have been considered representative of the formation conditions during V2 fluid circulation. Temperatures obtained from the V1 and V2 margins and their validity will be discussed below.

\section{FLUID INCLUSION MICROTHERMOMETRY}

Quartz from both vein generations shows numerous undermicron-sized fluid inclusions. Only a few bigger $(3-8 \mu \mathrm{m})$, liquid rich two-phase inclusions were measured $(n=184)$. Most inclusions are rounded to sub-rounded in shape and aligned obliquely to the main direction of the veins.

Fluid inclusions to the from V1 veins show homogenisation temperatures (Th) between 165 and $204^{\circ} \mathrm{C}(\mathrm{n}=30)$ with a mean value of $176 \pm 8^{\circ} \mathrm{C}$. Given the paucity of data, the standard deviation is large and no distribution patterns are perceived (Fig. 8A); this is probably due to non-isochoric behaviour. No salinity data were obtained due small inclusion size.

Fluid inclusions from V2 veins show a Th between 164 and $211^{\circ} \mathrm{C}(\mathrm{n}=154)$, with most values ranging between 176 and $191^{\circ} \mathrm{C}$. Altogether define a right-skewed normal distribution with a mean value of $184 \pm 7^{\circ} \mathrm{C}$ (Fig. $8 \mathrm{~A}$ ). Measured eutectic temperature (Te) for the two biggest inclusions $(\sim 12 \mu \mathrm{m})$ with a Th of 179 and $186^{\circ} \mathrm{C}$ indicates that the system corresponds to $\mathrm{NaCl}-\mathrm{H}_{2} \mathrm{O}$. The last phase to melt was the ice at -5 and $-6.5^{\circ} \mathrm{C}$, respectively, giving a salinity of $\sim$ wt.\% $\mathrm{NaCl}$ according to the Bodnar and Vityk (1994) equation. These results have been applied in the state equations of Bodnar and Vityk (1994) and Kinght and Bodnar (1989) through ISOC software (Bakker, 2003) to obtain the system isochore (Fig. 8B).

Formation temperature from chlorites hosted in CambrianOrdovician and Upper Ordovician rocks $(n=20)$ and in V2 vein centres $(n=43)$ were used together to obtain the pressure conditions through their correlation with the isochore (Appendix, Table III; Fig. 8B). Temperatures of $338 \pm 27^{\circ} \mathrm{C}, 369 \pm 23^{\circ} \mathrm{C}$ and $318 \pm 12^{\circ} \mathrm{C}$ obtained from Bourdelle et al. (2013), Lanari et al. (2014) (Chl2) and Inoue et al. (2018) geothermometers correspond to pressure values of $2.78 \pm 0.5 \mathrm{kbar}, 3.34 \pm 0.4 \mathrm{kbar}$ 
TABLE 1. Mean formation temperatures and $95 \%$ interval for the minimum and maximum values obtained from host rock and vein chlorites. Chlorites within the quartz veins are classified according to their in-vein location. Datasets are available in the Appendix, Table III

\begin{tabular}{|c|c|c|c|c|c|}
\hline Chlorite location & $\begin{array}{l}\text { In-vein } \\
\text { location (n) }\end{array}$ & Geothermometer & $\begin{array}{l}\text { Mean } \\
\text { value }\left({ }^{\circ} \mathrm{C}\right)\end{array}$ & $\begin{array}{l}\text { Minimum }\left({ }^{\circ} \mathrm{C}\right) \\
(95 \% \text { interval })\end{array}$ & $\begin{array}{l}\text { Maximum }\left({ }^{\circ} \mathrm{C}\right) \\
(95 \% \text { interval })\end{array}$ \\
\hline \multirow{3}{*}{$\begin{array}{l}\text { Serdinya Fm. } \\
\text { (Cambrian-Ordovician) }\end{array}$} & \multirow{3}{*}{$\begin{array}{l}- \\
(n=17)\end{array}$} & Bourdelle et al. (2013) & $349 \pm 34$ & 299 & 408 \\
\hline & & Lanari et al. (2014) & $380 \pm 32$ & 319 & 431 \\
\hline & & Inoue et al. (2018) & $320 \pm 13$ & 297 & 339 \\
\hline \multirow[t]{3}{*}{$\begin{array}{l}\text { Cava Fm. } \\
\text { (Upper Ordovician) }\end{array}$} & \multirow{3}{*}{$\begin{array}{l}- \\
(n=3)\end{array}$} & Bourdelle et al. (2013) & $372 \pm 24$ & 345 & 389 \\
\hline & & Lanari et al. (2014) & $407 \pm 17$ & 396 & 426 \\
\hline & & Inoue et al. (2018) & $327 \pm 9$ & 316 & 333 \\
\hline \multirow[t]{3}{*}{ V1 } & \multirow[t]{3}{*}{$\begin{array}{l}\text { Wall } \\
(n=7)\end{array}$} & Bourdelle et al. (2013) & $193 \pm 6$ & 182 & 200 \\
\hline & & Lanari et al. (2014) & $214 \pm 13$ & 195 & 231 \\
\hline & & Inoue et al. (2018) & $210 \pm 7$ & 197 & 218 \\
\hline \multirow[t]{6}{*}{ V2 } & \multirow[t]{3}{*}{$\begin{array}{l}\text { Wall } \\
(n=6)\end{array}$} & Bourdelle et al. (2013) & $250 \pm 32$ & 232 & 297 \\
\hline & & Lanari et al. (2014) & $273 \pm 11$ & 269 & 279 \\
\hline & & Inoue et al. (2018) & $257 \pm 22$ & 251 & 274 \\
\hline & \multirow{3}{*}{$\begin{array}{l}\text { Centre } \\
(n=43)\end{array}$} & Bourdelle et al. (2013) & $331 \pm 21$ & 303 & 361 \\
\hline & & Lanari et al. (2014) & $362 \pm 14$ & 336 & 387 \\
\hline & & Inoue et al. (2018) & $317 \pm 12$ & 300 & 335 \\
\hline
\end{tabular}

and $2.42 \pm 0.2 \mathrm{kbar}$, respectively (Fig. $8 \mathrm{~B}$ ). The utility of chlorite formation temperatures obtained from $\mathrm{V} 1$ and $\mathrm{V} 2$ vein walls (Fig. 7D) will be discussed below.

\section{DISCUSSION}

\section{Thermal balance between fluids and host rock}

The obtained chlorite formation temperature for the centre of V2 veins and for the host rock, both for the
Serdinya and the Cava fms., is ca. $318 \pm 12^{\circ} \mathrm{C}$ according to the Inoue et al. (2018) geothermometer (Figs. 7D; 8B; Table 1). Bourdelle et al. (2013) and Lanari et al. (2014) (Chl2) geothermometers gave similar mean values but with higher standard deviations (Figs. 7D; 8B; Table 1). This result is in accordance with veins formed under low fluid/ rock ratios and therefore, with expected thermal equilibrium between circulating fluids and rocks (Sharp et al., 2005 and references therein). However, these three geothermometers point to different and clearly lower temperature for chlorites in V1 veins, $210 \pm 7^{\circ} \mathrm{C}$ according to the Inoue et al. (2018)
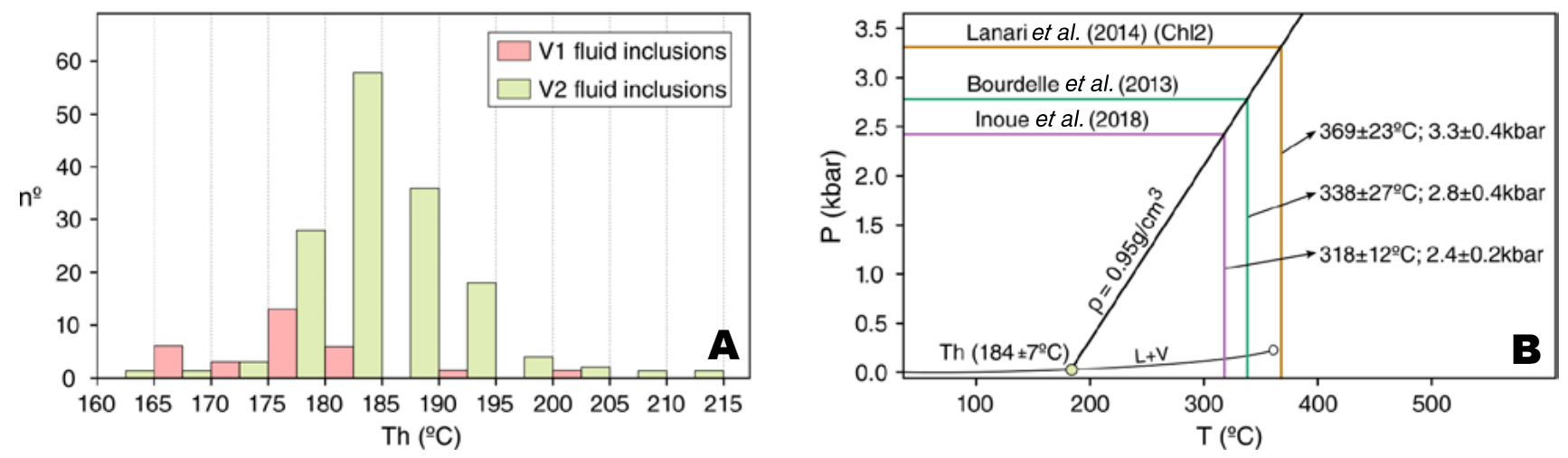

FIGURE 8. A) Histogram of the homogenization temperatures (Th) obtained from V1 and V2 fluid inclusions. B) P-T formation conditions of V2 veins obtained from the correlation between the isochore and the V2 centre and host rock formation temperatures. 
geothermometer (Table 1). These temperature differences for the three used geothermometers, around $100^{\circ} \mathrm{C}$, that are clearly greater than the maximum accepted errors of the methods, indicate different origins and conditions for the chlorites of V1 veins vs those of the host rocks and V2 veins.

The three geothermometers indicate slightly lower temperatures for chlorites in the walls of $\mathrm{V} 2$ veins (around $260^{\circ} \mathrm{C}$ ) than in the centre of $\mathrm{V} 2$ veins and the host rock (Fig. 7D). Conversely, differences in temperatures between wall and centre are predicted in veins formed by high fluid/ rock ratios, with thermal disequilibrium between fluids and rocks. This contradictory result needs to be addressed, because to assure thermal equilibrium between fluid and rock is a key point when fluid inclusion data are combined with an independent geothermometer to obtain pressure (Fig. 8). Once knowing the P-T condition for vein formation it would be possible to grasp the thermal gradient (see below).

To invoke a high fluid/rock ratio seems unlikely for this context since: i) similar chlorite formation temperatures were found in the host rock and the V2 centre (Fig. 7D; Table 1) and ii) no Th differences were found between fluid inclusions of the V2 wall and centre (Fig. 8A). Even the giant quartz veins formed at up to $400^{\circ} \mathrm{C}$ in the Alps show evidence of low fluid/rock ratios and hence, thermal balance between the hosting rocks and the circulating fluids, according to their $\delta^{18} \mathrm{O}$ (Sharp et al., 2005 and references therein).

The major requirement to use chlorite as a geothermometer is that the system must be in equilibrium. Furthermore, according to Essene and Peacor (1995) "the phases must be chemically and structurally well-defined". Therefore, we will focus on the chemistry of different chlorites, especially the ones hosted in the V2 vein walls. The EPMA results show higher $\mathrm{Si}$ and $\mathrm{Mg}$ and lower FeT content for chlorites in the vein walls compared to those located in either the vein centre or within the host rocks (Equations 5-7; Fig. 7A, B, C).

The EPMA analysis assumes total $\mathrm{Fe}$ as $\mathrm{FeO}$ (Appendix, Table III), so here we discuss what could be the influence of the real content of $\mathrm{Fe}^{3+}$ on the calculated temperature. Bourdelle et al. (2013) defended the notion that it is possible to calculate reliable formation temperatures without any measurement or assumption of the chlorite $\mathrm{Fe}^{3+}$ content (Bourdelle and Cathalineau, 2015). The Lanari et al. (2014) (Chl2) and Inoue et al. (2018) geothermometers estimate the $\mathrm{Fe}^{3+} / \mathrm{Fe}^{2+}+\mathrm{Fe}^{3+}$ via thermodynamic modelling (Verdeccia et al., 2019), but according to Masci et al. (2019), they are based on a restricted number of analyses. Thus, specific $\mathrm{Fe}^{3+}$ content of the chlorites of this study could be more or less out, or in the boundaries, of the application limits of the above mentioned semi-empirical thermometers, which would depend on the collection of the analyses used for their original calibration.

There are chlorite substitutions that involve the incorporation of $\mathrm{Fe}^{3+}$ in both tetrahedral (Munoz et al., 2013) and/or octahedral (Trincal and Lanari, 2016; Vidal et al., 2006) positions. According to Masci et al. (2019), the assumed $\mathrm{Fe}^{3+}$ increase goes together with an increment in octahedral vacancies. This is a mathematical effect of the normalisation criterion for the calculation of the chlorite formula, which is based on the number of oxygens, or equally, the balance of charge. The more $\mathrm{Fe}^{3+}$ that is assumed, the lower is the necessary total number of cations needed to balance the 28 negative charges of the chlorite formula. A coupled substitution of three divalent cations by two $\mathrm{Fe}^{3+}$ cations, which is a kind of di-trioctahedral substitution $\left(\square^{\mathrm{VI}}+2 \mathrm{Fe}^{3+}=3\left(\mathrm{Mg}, \mathrm{Fe}^{2+}\right)\right)$ has been proposed (Masci et al., 2019; Trincal and Lanari, 2016). Nevertheless, in the absence of external data on the real $\mathrm{Fe}^{3+}$ content, the extent of this substitution unfortunately remains masked by the mathematical relationship mentioned above. To conclude, the differences with the real content of $\mathrm{Fe}^{3+}$ in chlorites implicitly assumed by the geothermometer has a significant effect on the temperature obtained, as it modifies the number of vacancies through the formula calculation; this number of vacancies is key to the temperature determination as it determines the di-trioctahedral substitution.

The difference in $\mathrm{Fe}^{3+}$ quantity between the V2 wallhosted chlorites and those in the host rocks and V2 centre could have resulted in apparent differences to their formation temperature. To check the possible effect of differences of $\mathrm{Fe}^{3+} /$ total $\mathrm{Fe}$ ratios, we applied the geothermometers that allow consideration of this ratio, Lanari et al. (2014) (Chl1) and Inoue et al. (2009), for a suitable range of values (Vidal et al., 2016). Figures $7 \mathrm{E}$ and F, which display the effect of the $\mathrm{Fe}^{3+} /$ total $\mathrm{Fe}$ ratio on the calculated temperatures, show, for both geothermometers, the same temperature among the V2 wall-hosted chlorites and those in the host-rocks and $\mathrm{V} 2$ centre when different values for the $\mathrm{Fe}^{3+} /$ total $\mathrm{Fe}$ ratio are considered. As the real value of this parameter is unknown, the temperature of the chlorites may be the same, being the different results a consequence of the $\mathrm{Fe}^{3+}$ value assumption, similar to that of the population of samples used for the calibration of each semi-empirical geothermometer. The coinciding field is around $350^{\circ} \mathrm{C}$ for the Lanari et al. (2014) (Chl1) geothermometer (Fig. $7 \mathrm{E}$ ) and $300^{\circ} \mathrm{C}$ for the Inoue et al. (2009) geothermometer (Fig. 7F). This match interval is not far from the values obtained by the geothermometers which ignore the real $\mathrm{Fe}^{3+}$ content (Fig. 7D), with differences always inside the typical errors $\left( \pm 30^{\circ} \mathrm{C}\right.$ ) for the method (grey bands in Fig. $7 \mathrm{E}, \mathrm{F})$. Therefore, the considered temperature for $\mathrm{V} 2$ vein 
formation in this work is the one obtained from the vein centre, which matches the temperature of host rock chlorite (Fig. 8B; Table 1), pointing to low fluid/rock ratios.

Fluid circulation under low fluid/rock ratios implies static regimes with locally derived fluids (Yardley, 1975), fluid/rock interactions constrained by host rock properties (among them mineralogy, grain size or banding) and their deformational histories (e.g. Sharp et al., 2005; Van Noten and Sintubin, 2010). Quartz dissolution is favoured by pressure variations (e.g. Sharp et al., 2005), grain-grain contacts, high dislocation densities and small grain size (Yardley, 1975). Specifically, pressure solution in quartzquartz interfaces produces less dissolution than in quartzmica ones (Renard et al., 1997; Wangen and Munoz, 2004). Considering that the boundaries of the pre-Sardic phyllosilicate compaction bands (LVR) have many quartzmica interfaces, they might have acted as the main local source of silica (Fig. 5A, B). Upper Ordovician rocks do not show LVR, although some ( $5 \%)$ mica-quartz interfaces are present in the matrix (Fig. 5D, E).

According to Nakamura and Watson (2001), dissolved silica can diffuse into fractures over meters at a rate as high as $0.1-1 \mathrm{~m} /$ year. In the pre-Sardic-hosted V1 veins, diffusion heterogeneities are gathered by matching in-vein stripes with the phyllosilicate compaction bands in the adjacent host rock (Fig. 5A, B). The size and number of quartz crystals within the stripes correlate with the bands in the host rock (Fig. 5A, B). As quartz-mica boundaries support a thicker layer of water than the quartz-quartz ones (Niemeijer and Spires, 2002; Rendard et al., 1997), the diffusion pathways are enhanced by the numerous compaction bands boundaries (Fig. 5B). Conversely, inner zones of the phyllosilicate compaction bands probably acted as transmissivity barriers due to the impermeability gain corresponding to increasing phyllosilicate content (Parry et al., 2004). These low-permeability zones prevented silica diffusion into the veins, resulting in inner-vein stripes with minimum nucleation and therefore larger crystals (Fig. 5A, B). In contrast, no evidence of these features was found in veins hosted in the Upper Ordovician rocks.

\section{Quartz vein emplacement and the structure of the pre-Variscan rocks}

We differentiated two quartz vein generations (V1 and V2) based on differences in their orientation (Figs. 3;4), distribution (Fig. 4), and relationship with the deformational structures (Figs. 4; 5A, B, E, F). Variations of chlorite chemistry (Fig. $7 \mathrm{~A}, \mathrm{~B}, \mathrm{C})$ and their corresponding calculated temperatures (Fig. 7D; Table 1) also support this differentiation.

Concerning their age, V1 veins are affected by centimetric scale $D_{2}$ folds and crosscut by the $S_{2}$ cleavage, so pre- $\mathrm{D}_{2}$ emplacement may have occurred. Moreover, their occurrence around the Upper Ordovician Unconformity and the Upper Ordovician synsedimentary extensional faults suggest an emplacement that was linked to the sedimentation of the lowermost part of Upper Ordovician succession and to the Late Ordovician faulting episode (Fig. 4). Thus, we can interpret a relationship between the formation of V1 veins and the Sardic events, supporting the interpretations from Casas et al. (2019) and Puddu et al. (2019).

Besides the V1 veins, other deformational structures, previous to $\mathrm{D}_{2}$ and only affecting the Cambrian-Ordovician succession, have been identified in the study area: $S_{1}$ rough slaty cleavage (Fig. 5C) and pre-D folds (Fig. 2). Hartevelt (1970), Bons (1988) and Poblet (1991) also recognised a fabric prior to the development of the main phase cleavage in Central Pyrenees and in the Orri dome, but they concluded that this parallel bedding fabric is the result of sedimentation and compaction processes. Clariana and García-Sansegundo (2009) and GarcíaSansegundo et al. (2011) also described a $\mathrm{S}_{1}$ cleavage only recognisable in the Cambrian-Ordovician succession and not related to fold development in the Central Pyrenees (Garona and Pallaresa domes). These authors suggest that $\mathrm{S}_{1}$ could be related to a pre-Late Ordovician deformation event. In La Molina area, $S_{1}$ cleavage has been only identified at a microscopic scale and no relationship with folding structure was observed. Thus, $\mathrm{S}_{1}$ development cannot be unequivocally related to a Middle Ordovician (?) pre- $\mathrm{D}_{2}$ fold system. Alternatively, it could represent a Variscan poorly-developed cleavage near its upper front at shallow metamorphic levels, whereas it is well developed at deeper structural levels where it constitutes the main Variscan deformational mesostructure (Ayora and Casas, 1986; Carreras and Capellà, 1994; Santanach, 1972b). In the La Cerdanya area Puddu et al. (2019) described NESW oriented decametric to hectometric folds that were not related to cleavage formation or metamorphism, only affecting the pre-Sardic sequence. The similarities with the pre- $\mathrm{D}_{2}$ folds described in the La Molina area suggest that both fold systems may share a common origin. Finally, the distribution of $\mathrm{V} 1$ veins and their relationship with $\mathrm{D}_{2}$ mesostructures point to a pre-Variscan (Sardic-linked) age for this vein type (Fig. 4A).

Veins of V2 are parallel to the $S_{2}$ cleavage, either where $\mathrm{S}_{0}$ and $\mathrm{S}_{2}$ are perpendicular or oblique, near or far from the $\mathrm{D}_{2}$ fold hinge, respectively (Fig. 4). This points to a post- $\mathrm{D}_{2}$ emplacement for V2 veins. Therefore, V2 veins could be Variscan (after $\mathrm{D}_{2}$ deformation) or Alpine in age.

Classically, a Variscan age has been attributed to the deformation responsible for the main cleavage in the preAlpine basement rocks of the Pyrenees (see a review in 
Carreras and Capellà, 1994). In the equivalent rocks of the Serdinya Fm. of the Orri dome, Bons (1988) obtained palaeotemperatures between $250^{\circ} \mathrm{C}$ and $350^{\circ} \mathrm{C}$ on the basis of illite crystallinity data, which, for a geothermal gradient of $30^{\circ} \mathrm{C} \cdot \mathrm{km}-1$ would imply maximum pressures on the order of $2-3 \mathrm{kbar}$. In the same area, Cochelin et al. (2018) obtained similar temperatures, ca. $350^{\circ} \mathrm{C}$ by using Raman spectrometry analysis of carbonaceous material on muscovite-chlorite bearing metasediments. Cochelin et al. (2018) related these temperatures to Variscan metamorphism developed subsequent to the initiation of regional-scale folding and drawing flat isotherms with an estimated palaeothermal gradient of $45^{\circ} \mathrm{C} \cdot \mathrm{km}^{-1}$. According to this gradient, a depth of about $7.8 \mathrm{~km}$ for the cleavage development during Variscan times in the Orri dome can be estimated. Temperatures from Bons (1998) and Cochelin et al. (2018) are similar to those obtained in the study area for V2 veins and host rocks (Fig. 7D; Table 1). However, in the La Molina area this estimated depth is unrealistic unless several repetitions of the overlying Upper Ordovician, Silurian, Devonian and pre-Variscan Carboniferous (ca. 1,000m in thickness, Domingo et al., 1988; Martín-Closas et al., 2018) together with syn-orogenic Carboniferous successions (up to 1,000m in thickness, Sánz-López, 2019) occur. In addition, preserved Variscan structure of the Tossa d'Alp massif, close to la Molina, indicates that the thrust system affecting the post-Silurian rocks only produces a structural relief of ca. 2,000m (Domingo et al., 1988).

Alternatively, an Alpine age can be considered for the V2 veins. On the northern slope of the Canigó massif (Conflent area), Kister et al. (2003) obtained formation conditions of $309-405^{\circ} \mathrm{C}$ and $2.5-3.5 \mathrm{kbar}$ from a set of centimetricwidth quartz veins, applying purely empirical chlorite geothermometry and fluid inclusion microthermometry. According to them, these veins are parallel-to or related with fractures, fault sets, or shear zones and are aged as late-Variscan or Alpine. Applying the semi-empirical geothermometers of Bourdelle et al. (2013), Lanari et al. (2014) and Inoue et al. (2018) to their analyses, we have obtained temperature values of $308 \pm 54^{\circ} \mathrm{C}, 343 \pm 51^{\circ} \mathrm{C}$ and $308 \pm 25^{\circ} \mathrm{C}$, respectively, very similar to those from the $\mathrm{La}$ Molina V2 veins. In the Gavarnie thrust area, Henderson and McCaig (1996) studied Alpine quartz veins by estimating $\mathrm{P}-\mathrm{T}$ conditions of $5 \mathrm{kbar}$ and $330^{\circ} \mathrm{C}$ for the Pic Long and La Glère shear zones, and also applying empirical chlorite thermometry and fluid inclusion microthermometry. Semiempirical thermometry could not be applied to their chlorite analyses since the sum of octahedral sites is >5.95a.p.f.u. Nevertheless, the empirical formation temperatures of these Alpine veins are also similar to those obtained for the La Molina V2 ones with modern geothermometry.

In the Central Pyrenees, Lacroix et al. (2011, 2012) obtained palaeotemperatures of 208 and $240^{\circ} \mathrm{C}$ and pressures of 570 and 650bars, during the emplacement and fault reactivation of the Monte Perdido thrust sheet in the late Eocene-early Oligocene, respectively. These authors used fluid inclusions, oxygen isotopic fractionation, and chlorite thermometry data. Izquierdo-Lavall et al. (2013) obtained palaeotemperatures up to ca. $215^{\circ} \mathrm{C}$ based on vitrinite reflectance for the lowermost part of the Palaeogene succession in the Jaca basin. Combining this data with fluid inclusions they obtained a pressure of 8001,200bars, estimating a burial depth of ca. $6 \mathrm{~km}$. Lacroix et al. (2011, 2012) and Izquierdo-Lavall et al. (2013) get the same geothermal gradient of $34^{\circ} \mathrm{C} \cdot \mathrm{km}^{-1}$ but differently to what is proposed in this work, they assumed hydrostatic pressures. In the La Molina area, higher chlorite formation temperatures give higher pressures, and assuming a lithostatic pressure this gave a calculated burial depth of ca. $9 \mathrm{~km}$ and a geothermal gradient of $34^{\circ} \mathrm{C} \cdot \mathrm{km}^{-1}$. From regional stratigraphic data, Carrillo et al. (2014) estimated a thickness of ca. $5.6 \mathrm{~km}$ for the Eocene sequence in the south eastern Pyrenees. In La Molina area, thicknesses of ca. $500 \mathrm{~m}$ for the Late Cretaceous-Palaeogene succession and ca. 2,000m for the post-Upper Ordovician sequences should be added. As a result, a burial depth of ca. $8.1 \mathrm{~km}$ is achieved for Cambrian-Ordovician rocks in Eocene times based on stratigraphic criteria. This depth is comparable to that proposed in the Orri dome, but fitted in Variscan time by Cochelin et al. (2018) and close to that estimated for the La Molina area considering the Inoue et al. (2018) geothermometer.

\section{CONCLUSIONS AND FINAL REMARKS}

On the southern slope of the Canigó massif (La Molina area), we have differentiated two sets of decimetric-metric quartz veins (V1 and V2) based on differences in orientation, distribution and relationship with deformational structures. We posit that the generation of V1 veins is related to a Late Ordovician fracture episode, linked to the Middle-Late Ordovician Sardic events. We deduce that V2 veins were formed in a low fluid/rock ratio regime because analysis of in-vein and host rock chlorites yield the same formation temperatures. For the V2 veins, the combination of chlorite chemistry and fluid inclusion data provides a temperature of ca. $318 \pm 12^{\circ} \mathrm{C}$ and a pressure of $2.4 \pm 0.2 \mathrm{kbar}$, with an estimated geothermal gradient of $34^{\circ} \mathrm{C} \cdot \mathrm{km}^{-1}$, which indicate a burial depth of ca. $9 \mathrm{~km}$. After a comparison of these conditions with the ones in other areas of the Central and Eastern Pyrenees and based on stratigraphical criteria, we propose an Alpine age for the V2 veins.

Several questions are raised from these results. For instance, how representative are these data in the broader context of the Central and Eastern Pyrenees, and/or, what is the relationship between these metric veins and the 
larger ones spread throughout the pre-Alpine basement of the Eastern Pyrenees (Ayora and Casas, 1983; Ayora et al., 1984)? Giant veins are classically considered to be the expression of large quantities of circulating fluids that precipitate in regional-scaled brittle-ductile structures, under $200-300^{\circ} \mathrm{C}$ and $2-3 \mathrm{kbar}$ (Bons, 2001; Lemarchand et al., 2012). However, could these large quartz veins have formed at low fluid/rock ratios as has been suggested in the Alps (Sharp et al., 2005)? In the Eastern Pyrenees, although giant veins are mostly hosted by Variscan and pre-Variscan rocks, large fault-related quartz bodies also crosscut Mesozoic sedimentary rocks in some places (Fonseca et al., 2015; Liesa, 1988), being therefore Alpine in age.

Veins formed under low fluid/rock ratios are a palaeorecord of the P-T conditions within the enclosing rocks. Fluid inclusions, as a geobarometer through an independent geothermometer, as applied in this work, constitute an effective tool to establish the fluid/rock ratio; however, chlorite geothermometry requires caution. The formation conditions together with a well-known structural and thermal framework can help to establish the age of these large structures, whilst an accurate petrographic and geochemical characterisation can provide information on their formation constraints and mechanisms.

\section{ACKNOWLEDGMENTS}

The authors are grateful to Petroleum Experts for the use of MOVE® and to Carlos H. Grohmann for the use of Open Stereo software packages. Useful and detailed revisions made by Guillermo Booth-Rea and Gabriel Gutiérrez-Alonso, and technical editing have improved a first version of the manuscript. This paper is a contribution to 2017SGR-1733 Research Group and to projects CGL2017-87631-P and PGC2018-093903-B-C22 from the Ministerio de Ciencia, Innovación y Universidades/ Agencia Estatal de Investigación/Fondo Europeo de Desarrollo Regional, Unión Europea.

\section{REFERENCES}

Álvaro, J.J., Casas J.M., Clausen, S., Quesada C., 2018. Early Palaeozoic geodynamics in NW Gondwana. Journal of Iberian Geology, 44, 551-565. DOI: https://doi.org/10.1007/ s41513-018-0079-x

Aydin, A., Borja, R.I., Eichhubl, P., 2006. Geological and mathematical framework for failure modes in granular rock. Journal of Structural Geology, 28, 83-98. DOI: https://doi. org/10.1016/j.jsg.2005.07.008

Ayora, C., Casas, J.M., 1983. Estudi microtermomètric dels filons de quars de les Esquerdes de Rojà, Massís del Canigó. Acta Geológica Hispánica, 18(1), 35-46.

Ayora, C., Carreras, J., Casas, J.M., Liesa, M., 1984. Informe quarsos. Internal report. Barcelona, Universitat de Barcelona, unpublished.

Ayora, C., Casas, J.M., 1986. Strabound As-Au mineralization in pre-Caradocian rocks form the Vall de Ribes, Eastern Pyrenees, Spain. Mineralium Deposita, 21, 278-287.

Bakker, J.R., 2003. Package FLUIDS 1, Computer programs for Fluid Inclusion data and for modelling bulk fluid properties. Chemical Geology, 194, 3-23. DOI: https://doi.org/10.1016/ S0009-2541(02)00268-1.

Belaustegui, Z., Puddu, C., Casas, J.M., 2016. New ichnological data from the lower Paleozoic pf the Central Pyrenees: presence of Artrophycus Brogniartii (Harlam, 1832) in the Upper Ordovician Cava Formation. Geo-Temas, 16, 271-274.

Bodnar, R.J., 1993. Revised equation and table for determining the freezing point depression of $\mathrm{H} 2 \mathrm{O}-\mathrm{NaCl}$ solutions. Geochimica et Cosmochimica Acta, 57, 683-684. DOI: https://doi.org/10.1016/0016-7037(93)90378-A.

Bodnar, R.J., Vityk, M.O., 1994. Interpretation of microthermometric data for $\mathrm{H}_{2} \mathrm{O}-\mathrm{NaCl}$ fluid inclusions. In: De Vivo, B., Frezzoti, M.L. (eds.). Fluid Inclusions in minerals: Methods and Applications. Blacksburg, Virginia Tech, 117-130.

Bons, A.J., 1988. Intracrystalline deformation and slaty cleavage development in very low-grade slates from the Central Pyrenees. Geologica Ultraiectina, 56, 173pp.

Bons, P.D., 2000. The formation of veins and their microstructures. In: Jessell, M.W., Urai, J.L. (eds.). Stress, Strain and Structure, A Volume in Honour of W D Means. Journal of the Virtual Explorer. Last accessed: November 10th, 2020. Website: https://www.tectonique.net/MeansCD/wdmrom_pdf/bons. pdf. DOI: https://doi.org/10.3809/jvirtex.2000.00007

Bons, P.D., 2001. Development of crystal morphology during unitaxial growth in a progressively widening vein: I. The numerical model. Journal of Structural Geology 23, 865-872. DOI: https://doi.org/10.1016/j.jsg.2012.07.005

Bons, P.D., Elburg, M.A., Gomez-Rivas, E., 2012. A review of the formation of tectonic veins and their microstructures. Journal of Structural Geology, 43, 33-62.

Bourdelle, F, Parra, T., Chopin, C., Beyssac, O., 2013. A new chlorite geothermometer for diagenetic to low-grade metamorphic conditions. Contributions to Mineralogy and Petrology, 165, 723-735. DOI: https://doi.org/10.1007/s00410-012-0832-7

Bourdelle, F., Cathalineau, M., 2015. Low-temperature chlorite geothermometry: a graphical representation based on a T- $\mathrm{R}^{2+}$. Si diagram. European Journal of Mineralogy, 27, 617-626. DOI: https://doi.org/10.1127/ejm/2015/0027-2467

Carreras, J., Capellà, I., 1994. Tectonic levels in the Paleozoic basement of the Pyrenees: a review and a new interpretation. Journal of Structural Geology, 16, 1509-1524. DOI: https:// doi.org/10.1016/0191-81 41(94)90029-9

Carrillo, E., Rosell, L., Ortí, F, 2014. Multiepisodic evaporite sedimentation as an indicator of palaeogeographical evolution in foreland basins (South-eastern Pyrenean basin, EarlyMiddle Eocene). Sedimentology, 61, 2086-2112. DOI: https:// doi.org/10.1111/sed.12140 
Casas, J.M., Fernández, O., 2007. On the Upper Ordovician unconformity in the Pyrenees: New evidence from the La Cerdanya area. Geologica Acta, 5(2), 193-198. DOI: https:// doi.org/10.1344/105.000000304

Casas, J.M., 2010. Ordovician deformations in the Pyrenees: new insights into the significance of pre-Variscan ('sardic') tectonics. Geological Magazine, 147, 674-689. DOI: https:// doi.org/10.1017/S0016756809990756

Casas, J.M., Palacios, T., 2012. First biostratigraphical constraints on the pre-Upper Ordovician sequences of the Pyrenees based on organic-walled microfossils. Comptes Rendus Geosciences, 344(1), 50-56. DOI: https://doi.org/10.1016/j.crte.2011.12.003

Casas, J.M., Queralt, P., Menco J., Gratacós, O., 2012. Distribution of linear mesostructures in oblique folded surfaces: Unravelling superposed Ordovician and Variscan folds in the Pyrenees. Journal of Structural Geology, 44, 141-150. DOI: https://doi.org/10.1016/j.jsg.2012.08.013

Casas, J.M., Álvaro, J.J., Clausen, S., Padel, M., Puddu, C., SanzLópez, J., Sánchez-García, T., Navidad, M., Castiñeiras, P., Liesa, M., 2019. Palaeozoic basement of the Pyrenees. In: Quesada, C., Oliveira, J.T. (eds.). The Geology of Iberia: a Geodynamic Approach. Regional Geology Reviews series. Heidelberg, Springer, volume 2, chapter 8, 229-259.

Cavet, P., 1957. Le Paléozoïque de la zone axiale des Pyrénées orientales françaises entre le Roussillon et l'Andorre. Bulletin Service Carte Géologique France, 55, 303-518.

Clariana, P., García-Sansegundo, J., 2009. Variscan structure in the eastern part of the Pallaresa massif, Axial Zone of the Pyrenees (NW Andorra). Tectonic implications. Bulletin de la Société géologique de France, 180, 501-511. DOI: https://doi. org/10.2113/gssgfbull.180.6.501

Cocco, F, Funedda, A., 2019. The Sardic phase: field evidence of Ordovician tectonics in SE Sardinia, Italy. Geological Magazine, 156, 25-38. DOI: https://doi.org/10.1017/s0016 756817000723

Cochelin, B., Lemirre B., Denèle, Y., de Saint Blanquat, M., Lahfid, A., Duchêne, S., 2018. Structural inheritance in the Central Pyrenees: the Variscan to Alpine tectonometamorphic evolution of the Axial Zone. Journal of the Geological Society, 175, 336-351. DOI: https://doi.org/10.1144/jgs2017-066

Den Brok, S.W.J., 1989. Evidence for pre-Variscan deformation in the Lys Caillaouas area, Central Pyrenees, France. Geologie en Mijnbouw, 68, 377-380.

Domingo, F., Muñoz, J.A., Santanach, P., 1988. Estructures d'encavalcament en les materials del sòcol hercinia del massís de la Tossa d'Alp, Pirineu oriental. Acta Geologica Hispanica, 23, 141-53.

Durney, D.W., Ramsay, J.G., 1973. Incremental strains measured by syntectonic crystal growths. In: De Jong, K.A., Scholten, R.. (eds.). Gravity and Tectonics, John Wiley, 67-96.

Essene, E.J., Peacor, D.R., 1995. Clay mineral thermometry-a critical perspective. Clays and clay minerals, 43, 540-553. DOI: https://doi.org/10.1346/CCMN.1995.0430504.

Fonseca, H.A.M., Canals, A., Cirés, J., Casas, J.M., 2015. The Roses Giant Quartz Vein (Cap de Creus, Eastern Pyrenees):
Geology and Fluid Inclusion Data. MACLA, Revista de la Sociedad Española de Mineralogía, 20, 49-50.

Fossen, H., Schultz, R.A., Shipton, Z.K., Mair, K., 2007. Deformation bands in sandstone: a review. Journal of the Geological Society, 164, 755-769. DOI: https://doi. org/10.1144/0016-76492006-036.

Franceschelli, M., Mellini, M., Memmi, I., Ricci, C.A., 1986. Finescale chlorite-muscovite association in low-grade metapelites from Nurra (NW Sardinia) and the possible misidentification of metamorphic vermiculite. Contributions to Mineralogy and Petrology., 93, 137-143. DOI: https://doi.org/10.1007/ BF00371315

García-Sansegundo, J., Alonso, J.L., 1989. Stratigraphy and structure of the southeastern Garona Dome. Geodinamica Acta, 3, 127-134. DOI: https://doi.org/10.1080/09853111.19 89.11105180

García-Sansegundo, J., Gavaldà, J., Alonso, J.L., 2004. Preuves de la discordance de l'Ordovicien supérieur dans la zone axiale des Pyrénées: exemple de dôme de la Garonne (Espagne, France). Comptes Rendus Géoscience, 336, 1035-1040. DOI: https://doi.org/10.1016/j.crte.2004.03.009

García-Sansegundo, J., Poblet, J., Alonso, J.L., Clariana, P., 2011. Hinterland-foreland zonation of the Variscan orogen in the Central Pyrenees: Comparison with the northern part of the Iberian Variscan Massif. Geological Society London, 349 (Special Publications), 169-184. DOI: https://doi. org/10.1144/SP349.9

Gil-Peña, I., Barnolas, A., Villas, E., Sanz-López, J., 2004. El Ordovícico Superior de la Zona Axial. In: Vera J.A. (ed.). Geología de España. Madrid, Sociedad Geológica de España and Instituto Geológico y Minero de España (SGE-IGME), 247-24.

Guitard, G., 1970. Le métamorphisme hercynien mésozonal et les gneiss œillés du massif du Canigou (Pyrénées orientales). Mémoires du Bureau de Recherches Géologiques et Minières (BRGM), 63, 353pp.

Hartevelt, J.J.A., 1970. Geology of the upper Segre and Valira valleys, central Pyrenees, Andorra/Spain. Leidse Geologische Mededelingen, 45, 167-236.

Henderson, I.H.C., McCaig, A.M., 1996. Fluid pressure and salinity variations in shear zone-related veins, central Pyrenees, France: Implications for the fault-valve model. Tectonophysics, 262, 321-348. DOI: https://doi.org/10.1016/0040-1951(96)00018-2

Hey, M.H., 1954. A new review of the chlorites. Mineralogical Magazine, 224, 277-292.

Inoue, A., Meunier, A., Patrier-Mas, P., Rigault, C., Beaufort, D., Vieillard, P., 2009. Application of chemical geothermometry to low-temperature trioctahedral chlorites. Clays and Clay Minerals, 57, 371-382.

Inoue, A., Inoué, S., Utada, M., 2018. Application of chlorite thermometry to estimation of formation temperature and redox conditions. Clay Minerals, 53, 143-148. DOI: https:// doi.org/10.1180/clm.2018.10.

Izquierdo-Llavall, E., Aldega, L., Cantarelli, V., Corrado, S., GilPeña, I., Invernizzi, C., Casas, A.M., 2013. On the origin 
of cleavage in the Central Pyrenees: Structural and paleothermal study. Tectonophysics, 608, 303-318. DOI: https:// doi.org/10.1016/j.tecto.2013.09.027

Knight, C.L., Bodnar, R.J., 1989. Synthetic fluid inclusions: IX. Critical PVTX properties of $\mathrm{NaCl}-\mathrm{H} 2 \mathrm{O}$ solutions. Geochimica et Cosmochimica Acta, 53, 3-8. DOI: https://doi. org/10.1016/0016-7037(89)90267-6

Kister, P., Laumonier, B., Marignac, C., Boiron, M.C., 2003. Retrograde P-T-t-D path in a segment of a West-European Variscan belt: evidence for an anticlockwise path in the Canigou Massif (eastern Pyrenees) from fluid inclusion data. - EUG XII, Nice: 6-11 avril 2003, Geophysical Research Abstracts, 5, EAE03-A-11263.

Kriegsman, L.M., Aerden, D.G.A.M., Bakker, R.J., Den Brok, S.W.J., Schutjens, P.M.T.M., 1989. Variscan tectonometamorphic evolution of the eastern Lys-Caillaouas massif, Central Pyrenees-evidence for late orogenic extension prior to peak metamorphism. Geologie en Mijnbouw, 68, 323-333.

Lacroix, B., Buatier, M., Labaume, P., Travé, A., Dubois, M., Charpentier, D., Ventalon, S., Convert-Gaubier, D., 2011. Microtectonic and geochemical characterization of thrusting in a foreland basin: example of the South-Pyrenean orogenic wedge (Spain). Journal of Structural Geology, 33, 1359-1377. DOI: https://doi.org/10.1016/j.jsg.2011.06.006

Lacroix, B., Charpentier, D., Buatier, M., Vennemann, T., Labaume, P., Adatte, T., Travé, A., Dubois, M., 2012. Formation of chlorite during thrust fault reactivation. Record of fluid origin and $\mathrm{P}-\mathrm{T}$ conditions in the Monte Perdido thrust fault (southern Pyrenees). Contributions to Mineralogy and Petrology, 163, 1083-1102. DOI: https://doi.org/10.1007/s00410-011-0718-0

Lanari, P., Wagner, T., Vidal, O., 2014. A thermodynamic model for di-trioctaedrical chlorite from experimental and natural data in the system $\mathrm{MgO}-\mathrm{FeO}-\mathrm{Al} 2 \mathrm{O} 3-\mathrm{SiO} 2-\mathrm{H} 2 \mathrm{O}$ : applications to P-T sections and geothermometry. Contributions to Mineralogy and Petrology, 167. 1-19. DOI: https://doi. org/10.1007/s00410-014-0968-8

Laumonier, B., 1988. Les groupes de Canaveilles et de Jujols ("Paléozoïque inférieur") des Pyrénées orientales arguments en faveur de l'âge essentiellement Cambrien de ces séries. Hercynica, 4, 25-38.

Lemarchand, J., Boulvais, P., Gaboriau, M., Boiron, M.-C., Tartèse, R., Cokkinos, M., Bonnet, S., Jégouzo, P., 2012. Giant quartz vein formation and high-elevation meteoric fluid infiltration into the South Armorican Shear Zone: geological, fluid inclusion and sta- ble isotope evidence. Journal of the Geological Society, 169, 17-27. DOI: https:// doi.org/10.1144/0016- 76492010-186

Liesa, M., 1988. El metamorfisme del vessant sud del Massís del Roc de Frausa (Pirineus Orientals). Doctoral Thesis. Barcelona, Universitat de Barcelona, unpublished, 233pp.

Margalef, A., Casas, J.M., 2016. Corte geológico compensado del sur de Andorra: aportaciones a la estructura varisca del Pirineo central. Geo-Temas, 16, 61-63.

Margalef, A., Castiñeiras, P., Casas, J.M., Navidad, M., Liesa, M., Linnemann, U., Hofmann, M., Gärtner, A.,
2016. Detrital zircons from the Ordovician rocks of the Pyrenees: Geochronological constraints and provenance. Tectonophysics, 681, 124-134. DOI: https://doi.org/10.1016/j. tecto.2016.03.015

Martín-Closas, C., Trias, S., Casas, J.M., 2018. New palaeobotanical data from Carboniferous Culm deposits constrain the age of the Variscan deformation in the Eastern Pyrenees. Geologica Acta, 16(2), 107-123. DOI: https://doi.org/10.1344/ GeologicaActa2018.16.2.1

Masci, L., Dubacq, B., Verlaguet, A., Chopin, C., De Andrade, V., Herviou, C., 2019. A XANES and EPMA study of Fe3+ in chlorite: Importance of oxychlorite and implications for cation site distribution and thermobarometry. American Mineralogist, 104, 403-417. DOI: https://doi.org/10.2138/ am-2019-6766

Mellini, M., Nieto, F., Alvarez, F., Gomez-Pugnaire, M.T., 1991. Mica-chlorite intermixing and altered chlorite from the Nevado-Filabride micaschists, Southern Spain. European Journal of Mineralogy, 3, 27-38. DOI: https://doi.org/10.1127/ ejm/3/1/0027

Mey, P.H.W., 1967. The geology of the Upper Ribagorzana and Baliera valleys, Central Pyrenees, Spain. Leidse Geologische Mededelingen, 41, 153-220.

Muñoz, J.A., 1992a. Evolution of a continental collision belt: ECORS-Pyrenees crustal balanced cross-section. In: Mc Clay, K.R. (ed.). Thrust Trectonics. London, Chapman \& Hall, 235246.

Muñoz, J.A. 1992b. Estructura alpina i herciniana a la vora sud de la Zona Axial del Pirineu oriental. Monografies núm. 1. Publicació del Servei Geològic de Catalunya, Barcelona: Generalitat de Catalunya, Departament de Política Territorial i Obres Públiques, Servei Geologic de Catalunya, 227pp.

Munoz, M., Vidal, O., Marcaillou, C., Pascarelli, S., Mathon, O., Farges, F., 2013. Iron oxidation state in phyllosilicate single crystals using $\mathrm{Fe}-\mathrm{K}$ pre-edge and XANES spectroscopy: Effects of the linear polarization of the synchrotron $\mathrm{X}$ ray beam. American Mineralogist, 98, 1187-1197. DOI: https:// doi.org/10.2138/am.2013.4289

Nakamura, M., Watson, E.B., 2001. Experimental study of aqueous fluid infiltration into quartzite: implications for the kinetics of fluid redistribution and grain growth driven by interfacial energy reduction. Geofluids, 1, 73-89. DOI: https:// doi.org/10.1046/j.1468-8123.2001.00007.x

Navidad, M., Castiñeiras, P., Casas, J.M., Liesa, M., Belousova, E., Proenza, J., Aiglsperger, T., 2018. Ordovician magmatism in the Eastern Pyrenees: Implications for the geodynamic evolution of northern Gondwana. Lithos, 314, 479-496. DOI: https://doi.org/10.1016/j.lithos.2018.06.019

Niemeijer, A.R., Spires, C.J., 2002. Compaction creep of quartzmuscovite mixtures at $500^{\circ} \mathrm{C}$ : Preliminary results on the influence of muscovite on pressure solution. London, Geological Society, 200 (Special Publications), 61-71. DOI: https://doi.org/10.1144/GSL.SP.2001.200.01.04

Padel, M., Álvaro, J.J., Casas, J.M., Clausen, S., Poujol, M., Sánchez-García, T., 2018a. Cadomian volcanosedimentary 
complexes across the Ediacaran-Cambrian transition of the Eastern Pyrenees, southwestern Europe. International Journal of Earth Sciences, 107, 1579-1601. DOI: https://doi. org/10.1007/s00531-017-1559-5

Padel, M., Clausen, S., Álvaro, J.J., Casas, J.M. 2018b. Review of the Ediacaran-Lower Ordovician (pre-Sardic) stratigraphic framework of the Eastern Pyrenees, southwestern Europe. Geologica Acta, 16, 339-355. DOI: https://doi.org/10.1344/ GeologicaActa2018.16.4.1

Parry, W.T., Chan, M.A., Beitler, B., 2004. Chemical bleaching indicates episodes of fluid flow in deformation bands in sandstone. American Association of Petroleum Geologists (AAPG) Bulletin, 88, 175-191.

Pasci, S., Pertusati, PC., Salvadori, I., Murtas, A., 2008. I rilevamenti CARG del Foglio geologico 555 "Iglesias" e le nuove implicazioni strutturali sulla tettonica della "Fase Sarda". Rendiconti online della Società Geologica Italiana, Abstracts, 3, 614-615.

Pereira, M.F., Castro, A., Chichorro, M., Fernández, C., DíazAlvarado, J., Martí, J., Rodríguez, C., 2014. Chronological link between deep-seated processes in magma chambers and eruptions: Permo-Carboniferous magmatism in the core of Pangaea (Southern Pyrenees). Gondwana Research, 25, 290308. DOI: https://doi.org/10.1016/j.gr.2013.03.009

Pillola, G.L., Piras, S., Serpagli, E., 2008. Upper TremadocLower Arenig? Anisograptid-Dichograptid fauna from the Cabitza Formation (Lower Ordovician, SW Sardinia, Italy). Revue de Micropaléontologie, 51, 167-181. DOI: https://doi. org/10.1016/j.revmic.2007.08.002

Poblet, J., 1991. Estructura herciniana i alpina del vessant sud de la zona axial del Pirineu central. PhD thesis. Barcelona, Universitat de Barcelona, unpublished, 604pp.

Puddu, C., Carrera, N., Casas, J.M., 2019. Deciphering the Sardic (Ordovician) and Variscan deformations in the Eastern Pyrenees, SW Europe. Journal of the Geological Society, 176, 1191-1206. DOI: https://doi.org/10.1144/jgs2019-057

Ramsay, J.G., 1967. Folding and fracturing of rocks. New York, Mac Graw-Hill, 568pp.

Ramsay, J.G., 1980. The crack seal mechanism of rock deformation. Nature, 284, 135-139. DOI: https://doi.org/10.1038/284135a0

Renard, F., Ortoleva, P., Gratier, J.P., 1997. Pressure solution in sandstones: influence of clays and dependence on temperature and stress. Tectonophysics, 280, 257-266. DOI: https://doi. org/10.1016/S0040-1951(97)00039-5

Santanach, P.F, 1972a. Sobre una discordancia en el Paleozoico inferior de los Pirineos orientales. Acta Geológica Hispánica, 7, 129-132.

Santanach, P.F, 1972b. Estudio tectónico del Paleozoico inferior del Pirineo entre la Cerdaña y el río Ter. Acta Geológica Hispánica, 7, 44-49.

Sánz-López, J. 2019. Synorogenic Eastern Iberian Peninsula Basins Related to the Paleotethys Margin. In: Quesada, C., Oliveira, J.T. (eds.). The Geology of Iberia: a Geodynamic Approach. Heidelberg, Springer, Regional Geology Reviews series, volume 2, chapter 11.4, 408-429.
Sharp, Z.D., Masson, H., Lucchini, R., 2005. Stable isotope geochemistry and formation mechanisms of quartz veins; extreme paleoaltitudes of the central alps in the Neogene. American Journal of Science, 305, 187-219. DOI: https://doi. org/10.2475/ajs.305.3.187

Sibson, R., 1981. A brief description of natural neighbour interpolation. In: Barnett, V. (ed.). Interpolating Multivariate Data. Chichester, John Wiley, chapter 2, 21-36. DOI: https:// doi.org/10.1007/3-540-26772-7_8

Speksnijder, A., 1986. Geological analysis of Paleozoic large-scale faulting in the south-central Pyrenees. Geologica Ultraiectina, 43, 1-211.

Teichmüller, R., 1931. Zur Geologie des Yhyrrenisbebietes, Teill: Alte und junge Krustenbewegungen im südlinchen Dardinien. Abhandlungen der Gesellschaft (Akademie) der Wissenschaften, Gottingen, 3, 857-950.

Trincal, V., Lanari, P., 2016. Al-free di-trioctahedral substitution in chlorite and a ferri-sudoite end-member. Clay Minerals, 51, 675-689. DOI: https://doi.org/10.1180/claymin.2016.051.4.09

Turner, FJ., Weiss, L.E. 1963. Structural analysis of metamorphic tectonites. New Cork, Mac Graw-Hill, 545pp.

Van Noten, K., Sintubin, M., 2010. Linear to non-linear relationship between vein spacing and layer thickness in centimetre- to decimetre-scale siliciclastic multilayers from the High-Ardenne slate belt (Belgium, Germany). Journal of Structural Geology, 32, 377-391. DOI: https://doi.org/10.1016/j.jsg.2010.01.011

Verdecchia, S.O., Collo, G., Zandomeni, P.S., Wunderlin, C., Fehrmann, M., 2019. Crystallochemical indexes and geothermobarometric calculations as a multiproxy approach to P-T condition of the low-grade metamorphism: The case of the San Luis Formation, Eastern Sierras Pampeanas of Argentina. Lithos, 323-324, 385401. DOI: https://doi.org/10.1016/j.lithos.2018.11.021

Vidal, O., De Andrade, V., Lewin, E., Muñoz, M., Parra, T., Pascarelli, S., 2006. P-T-deformation- $\mathrm{Fe}^{3+} / \mathrm{Fe}^{2+}$ mapping at the thin section scale and comparison with XANES mapping: Application to a garnet-bearing metapelite from the Sambagawa metamorphic belt (Japan). Journal of Metamorphic Geology, 24, 669-683. DOI: https://doi.org/10.1111/j.1525-1314.2006.00661.x

Vidal, O., Lanari, P., Munoz, M., Bourdelle, F., de Andrade, V., 2016. Deciphering temperature, pressure and oxygen activity conditions of chlorite formation. Clay Minerals, 51, 615-633. DOI: https://doi.org/10.1180/claymin.2016.051.4.06

Wangen, M., Munoz, I.A., 2004. Formation of quartz veins by local dissolution and transport of silica. Chemical Geology, 209, 179-192. DOI: https://doi.org/10.1016/j.chemgeo.2004.02.011

Yardley, B.W.D., 1975. On some quartz-plagioclase veins in the Connemara schists, Ireland. Geological Magazine, 112, 183190. DOI: https://doi.org/10.1017/S0016756800045866

Zwart, H.J., 1979. The geology of the central Pyrenees. Leidse Geologische Mededelingen, 50, 1-74.

Manuscript received April 2020; revision accepted October 2020; published Online November 2020. 


\section{APPENDIX I}

TABLE I. Spatial distribution throughout the study area of V1 and V2 $\left(>0.5 \mathrm{~cm}\right.$ thick) quartz veins outcropping per $\mathrm{m}^{2}$

\begin{tabular}{|c|c|c|c|c|c|c|}
\hline POINT ID & X (UTM) & Y (UTM) & $\mathrm{Z}$ (masl) & $\mathrm{N}_{\mathrm{V} 1(>0.5 \mathrm{~cm})} / \mathrm{m}^{2}$ & $\mathrm{~N}_{\mathrm{V} 2(>0.5 \mathrm{~cm})} / \mathrm{m}^{2}$ & $\mathrm{NV} 1+\mathrm{NV} 2$ \\
\hline 1 & 414237,86 & 4688362,41 & 1452,2 & 2 & 9 & 11 \\
\hline 2 & 414193,36 & 4688374,91 & 1434,5 & 3 & 8 & 11 \\
\hline 3 & 414221,73 & 4688376,47 & 1445,3 & 2 & 6 & 8 \\
\hline 4 & 414211,05 & 4688354,60 & 1443,5 & 1 & 7 & 8 \\
\hline 5 & 414244,11 & 4688347,06 & 1455,5 & 4 & 6 & 10 \\
\hline 6 & 414265,45 & 4688403,54 & 1457,9 & 4 & 6 & 10 \\
\hline 7 & 414288,10 & 4688402,76 & 1466,1 & 3 & 5 & 8 \\
\hline 8 & 414283,15 & 4688380,37 & 1465,9 & 3 & 6 & 9 \\
\hline 9 & 414311,53 & 4688399,11 & 1475,1 & 3 & 4 & 7 \\
\hline 10 & 414321,94 & 4688418,90 & 1474,9 & 1 & 7 & 8 \\
\hline 11 & 414307,62 & 4688440,50 & 1467,2 & 3 & 3 & 6 \\
\hline 12 & 414082,73 & 4688321,03 & 1432,1 & 0 & 9 & 9 \\
\hline 13 & 414082,99 & 4688304,89 & 1432,0 & 5 & 5 & 10 \\
\hline 14 & 414070,24 & 4688354,60 & 1441,7 & 5 & 3 & 8 \\
\hline 15 & 414242,32 & 4688363,35 & 1453,8 & 4 & 5 & 9 \\
\hline 16 & 414280,22 & 4688424,75 & 1459,7 & 2 & 8 & 10 \\
\hline 17 & 414283,26 & 4688428,28 & 1459,9 & 1 & 5 & 6 \\
\hline 18 & 414431,94 & 4688525,39 & 1454,9 & 1 & 4 & 5 \\
\hline 19 & 414427,92 & 4688442,48 & 1489,6 & 2 & 5 & 7 \\
\hline 20 & 414426,11 & 4688435,83 & 1491,4 & 2 & 3 & 5 \\
\hline 21 & 414431,17 & 4688436,85 & 1491,8 & 1 & 2 & 3 \\
\hline 22 & 414433,17 & 4688440,55 & 1490,4 & 5 & 4 & 9 \\
\hline 23 & 414448,83 & 4688440,94 & 1492,2 & 5 & 5 & 10 \\
\hline 24 & 414449,65 & 4688440,11 & 1492,6 & 5 & 3 & 8 \\
\hline 25 & 414442,99 & 4688437,07 & 1492,8 & 4 & 5 & 9 \\
\hline 26 & 414447,28 & 4688450,62 & 1488,4 & 6 & 6 & 12 \\
\hline 27 & 414459,33 & 4688454,74 & 1488,7 & 2 & 4 & 6 \\
\hline 28 & 414751,46 & 4688347,51 & 1459,5 & 1 & 7 & 8 \\
\hline 29 & 414760,09 & 4688340,46 & 1458,1 & 5 & 5 & 10 \\
\hline 30 & 414761,52 & 4688335,51 & 1458,9 & 0 & 3 & 3 \\
\hline 31 & 414765,55 & 4688329,07 & 1458,9 & 6 & 6 & 12 \\
\hline 32 & 414785,32 & 4688343,54 & 1457,0 & 0 & 5 & 5 \\
\hline 33 & 414798,06 & 4688310,12 & 1460,9 & 1 & 3 & 4 \\
\hline 34 & 414802,25 & 4688312,67 & 1461,5 & 0 & 6 & 6 \\
\hline 35 & 414784,60 & 4688339,67 & 1458,0 & 1 & 7 & 8 \\
\hline 36 & 414659,25 & 4688389,88 & 1498,9 & 1 & 7 & 8 \\
\hline 37 & 414644,14 & 4688399,60 & 1499,3 & 3 & 5 & 8 \\
\hline 38 & 414604,31 & 4688494,79 & 1465,0 & 4 & 4 & 8 \\
\hline 39 & 414608,74 & 4688493,86 & 1465,4 & 1 & 6 & 7 \\
\hline 40 & 414592,84 & 4688491,07 & 1468,9 & 0 & 4 & 4 \\
\hline 41 & 414591,18 & 4688492,41 & 1467,9 & 1 & 4 & 5 \\
\hline 42 & 414595,66 & 4688486,97 & 1471,0 & 0 & 6 & 6 \\
\hline 43 & 414564,19 & 4688472,83 & 1481,7 & 1 & 5 & 6 \\
\hline 44 & 414534,20 & 4688480,89 & 1478,5 & 2 & 4 & 6 \\
\hline 45 & 414491,65 & 4688502,73 & 1467,7 & 2 & 5 & 7 \\
\hline 46 & 414488,48 & 4688499,69 & 1468,9 & 2 & 1 & 3 \\
\hline 47 & 414173,52 & 4688367,51 & 1430,0 & 2 & 1 & 3 \\
\hline 48 & 414152,50 & 4688319,91 & 1430,0 & 7 & 3 & 10 \\
\hline
\end{tabular}

\begin{tabular}{|c|c|c|c|c|c|c|}
\hline POINT ID & $\mathrm{X}$ (UTM) & Y (UTM) & $\mathrm{Z}$ (masl) & $\mathrm{N}_{\mathrm{V} 1(00.5 \mathrm{~cm})} / \mathrm{m}^{2}$ & $\mathrm{~N}_{\mathrm{V} 2(>0.5 \mathrm{~cm})} / \mathrm{m}^{2}$ & ${ }^{2} \mathrm{NV} 1+\mathrm{NV} 2$ \\
\hline 49 & 414159,93 & 4688347,25 & 1429,0 & 3 & 6 & 9 \\
\hline 50 & 414161,41 & 4688352,01 & 1429,0 & 2 & 1 & 3 \\
\hline 51 & 414157,97 & 4688359,25 & 1430,0 & 2 & 3 & 5 \\
\hline 52 & 414158,36 & 4688372,87 & 1430,0 & 4 & 8 & 12 \\
\hline 53 & 414154,13 & 4688373,51 & 1429,8 & 3 & 6 & 9 \\
\hline 54 & 414155,95 & 4688369,85 & 1430,0 & 1 & 9 & 10 \\
\hline 55 & 414163,35 & 4688410,30 & 1425,0 & 2 & 6 & 8 \\
\hline 56 & 414167,21 & 4688411,98 & 1425,0 & 2 & 5 & 7 \\
\hline 57 & 414177,69 & 4688401,89 & 1425,9 & 2 & 4 & 6 \\
\hline 58 & 414178,21 & 4688403,59 & 1425,5 & 7 & 7 & 14 \\
\hline 59 & 414176,65 & 4688409,44 & 1425,0 & 4 & 5 & 9 \\
\hline 60 & 414175,32 & 4688393,96 & 1426,1 & 8 & 7 & 15 \\
\hline 61 & 414185,12 & 4688388,34 & 1431,0 & 6 & 4 & 10 \\
\hline 62 & 414163,59 & 4688424,38 & 1424,9 & 7 & 7 & 14 \\
\hline 63 & 414178,93 & 4688429,94 & 1425,0 & 2 & 5 & 7 \\
\hline 64 & 414186,19 & 4688442,23 & 1425,7 & 7 & 8 & 15 \\
\hline 65 & 414186,93 & 4688439,21 & 1426,0 & 6 & 6 & 12 \\
\hline 66 & 414181,34 & 4688435,30 & 1425,0 & 8 & 4 & 12 \\
\hline 67 & 414183,61 & 4688446,95 & 1424,6 & 6 & 7 & 13 \\
\hline 68 & 414183,38 & 4688448,42 & 1424,5 & 7 & 8 & 15 \\
\hline 69 & 414190,28 & 4688450,86 & 1426,3 & 1 & 6 & 7 \\
\hline 70 & 414193,29 & 4688428,64 & 1429,5 & 5 & 4 & 9 \\
\hline 71 & 414219,93 & 4688421,71 & 1439,0 & 3 & 6 & 9 \\
\hline 72 & 414225,77 & 4688391,07 & 1445,3 & 3 & 4 & 7 \\
\hline 73 & 414222,05 & 4688383,85 & 1444,5 & 2 & 4 & 6 \\
\hline 74 & 414204,27 & 4688390,71 & 1436,8 & 3 & 6 & 9 \\
\hline 75 & 414229,28 & 4688428,36 & 1441,6 & 2 & 7 & 9 \\
\hline 76 & 414273,26 & 4688444,18 & 1455,0 & 4 & 5 & 9 \\
\hline 77 & 414263,44 & 4688500,10 & 1435,9 & 1 & 4 & 5 \\
\hline 78 & 414268,71 & 4688522,91 & 1428,9 & 1 & 6 & 7 \\
\hline 79 & 414247,92 & 4688513,12 & 1425,8 & 1 & 3 & 4 \\
\hline 80 & 414248,84 & 4688507,82 & 1427,2 & 1 & 5 & 6 \\
\hline 81 & 414209,62 & 4688498,75 & 1424,9 & 1 & 6 & 7 \\
\hline 82 & 414205,95 & 4688507,88 & 1424,0 & 6 & 5 & 11 \\
\hline 83 & 414218,17 & 4688505,07 & 1425,0 & 3 & 8 & 11 \\
\hline 84 & 414221,39 & 4688507,59 & 1425,0 & 2 & 7 & 9 \\
\hline 85 & 414230,39 & 4688513,01 & 1425,0 & 4 & 8 & 12 \\
\hline 86 & 414239,24 & 4688522,89 & 1424,0 & 2 & 9 & 11 \\
\hline 87 & 414248,71 & 4688520,41 & 1424,3 & 1 & 6 & 7 \\
\hline 88 & 414242,20 & 4688532,76 & 1425,0 & 2 & 5 & 7 \\
\hline 89 & 414238,15 & 4688532,08 & 1424,7 & 0 & 4 & 4 \\
\hline 90 & 414231,14 & 4688527,39 & 1425,0 & 2 & 4 & 6 \\
\hline 91 & 414222,11 & 4688519,23 & 1425,0 & 1 & 7 & 8 \\
\hline 92 & 414221,34 & 4688526,88 & 1425,0 & 0 & 8 & 8 \\
\hline 93 & 414209,18 & 4688521,94 & 1424,7 & 1 & 5 & 6 \\
\hline 94 & 414204,02 & 4688542,61 & 1427,0 & 1 & 4 & 5 \\
\hline 95 & 414203,02 & 4688542,20 & 1426,8 & 1 & 6 & 7 \\
\hline 96 & 414197,21 & 4688528,01 & 1424,0 & 2 & 8 & 10 \\
\hline 97 & 414194,95 & 4688515,64 & 1423,0 & 1 & 6 & 7 \\
\hline 98 & 414187,72 & 4688501,91 & 1421,0 & 2 & 5 & 7 \\
\hline
\end{tabular}


TABLE I. Continued

\begin{tabular}{|c|c|c|c|c|c|c|c|c|c|c|c|c|c|}
\hline POINT ID & X (UTM) & Y (UTM) & $\mathrm{Z}$ (masl) & $\mathrm{N}_{\mathrm{V} 1(>0.5 \mathrm{~cm})} / \mathrm{m}^{2}$ & $\mathrm{~N}_{\mathrm{V} 2(>0.5 \mathrm{~cm})} / \mathrm{m}^{2}$ & $\mathrm{NV} 1+\mathrm{NV} 2$ & POINT ID & X (UTM) & $\mathrm{Y}$ (UTM) & $\mathrm{Z}$ (masl) & $\mathrm{N}_{\mathrm{V} 1(>0.5 \mathrm{~cm})} / \mathrm{m}^{2}$ & $\mathrm{~N}_{\mathrm{V} 2(>0.5 \mathrm{~cm})} / \mathrm{m}^{2}$ & $\mathrm{NV} 1+\mathrm{NV} 2$ \\
\hline 99 & 414198,07 & 4688499,70 & 1422,3 & 4 & 4 & 8 & 149 & 414745,91 & 4688099,55 & 1513,7 & 1 & 4 & 5 \\
\hline 100 & 414213,66 & 4688469,55 & 1430,4 & 3 & 3 & 6 & 150 & 414806,06 & 4687909,72 & 1553,0 & 2 & 4 & 6 \\
\hline 102 & 414178,30 & 4688492,28 & 1420,5 & 4 & 5 & 9 & 152 & 414510,65 & 4687848,36 & 1597,6 & 2 & 3 & 5 \\
\hline 103 & 414175,58 & 4688469,47 & 1420,0 & 3 & 6 & 9 & 153 & 414737,14 & 4687871,50 & 1579,9 & 1 & 4 & 5 \\
\hline 104 & 414181,96 & 4688462,81 & 1422,0 & 5 & 7 & 12 & 154 & 414692,66 & 4687845,18 & 1604,8 & 2 & 6 & 8 \\
\hline 105 & 414186,17 & 4688464,44 & 1423,0 & 4 & 7 & 11 & 155 & 414650,68 & 4687858,97 & 1608,9 & 2 & 4 & 6 \\
\hline 106 & 414166,94 & 4688481,36 & 1420,0 & 2 & 6 & 8 & 156 & 414461,47 & 4687967,36 & 1564,1 & 3 & 5 & 8 \\
\hline 107 & 414166,47 & 4688501,21 & 1420,9 & 0 & 4 & 4 & 157 & 414610,67 & 4688154,60 & 1535,0 & 8 & 6 & 14 \\
\hline 108 & 414158,41 & 4688520,96 & 1420,2 & 1 & 4 & 5 & 158 & 414368,74 & 4687947,31 & 1561,9 & 2 & 5 & 7 \\
\hline 109 & 414162,01 & 4688531,47 & 1421,0 & 2 & 6 & 8 & 159 & 414311,10 & 4687931,02 & 1560,9 & 5 & 4 & 9 \\
\hline 110 & 414169,97 & 4688527,91 & 1422,0 & 1 & 7 & 8 & 160 & 414359,97 & 4688033,14 & 1522,9 & 1 & 5 & 6 \\
\hline 111 & 414179,90 & 4688530,07 & 1422,9 & 3 & 5 & 8 & 161 & 414301,08 & 4687971,74 & 1546,2 & 3 & 6 & 9 \\
\hline 113 & 414150,29 & 4688532,75 & 1420,0 & 1 & 1 & 2 & 163 & 414236,55 & 4688063,22 & 1496,6 & 4 & 7 & 11 \\
\hline 114 & 414156,77 & 4688542,92 & 1420,0 & 1 & 4 & 5 & 164 & 414020,33 & 4688776,59 & 1420,0 & 5 & 5 & 10 \\
\hline 115 & 414167,11 & 4688541,00 & 1422,0 & 5 & 6 & 11 & 165 & 414012,40 & 4688848,41 & 1411,0 & 3 & 7 & 10 \\
\hline 116 & 414158,24 & 4688550,35 & 1420,0 & 1 & 4 & 5 & 166 & 414035,52 & 4688837,32 & 1411,0 & 1 & 8 & 9 \\
\hline 117 & 414157,51 & 4688562,63 & 1420,0 & 2 & 5 & 7 & 167 & 414085,27 & 4688878,56 & 1412,0 & 1 & 6 & 7 \\
\hline 118 & 414145,80 & 4688557,30 & 1420,0 & 1 & 4 & 5 & 168 & 414142,98 & 4688858,96 & 1420,2 & 1 & 5 & 6 \\
\hline 119 & 414170,55 & 4688566,13 & 1424,5 & 1 & 7 & 8 & 169 & 414168,51 & 4688810,87 & 1419,4 & 1 & 6 & 7 \\
\hline 120 & 414178,45 & 4688567,02 & 1426,6 & 0 & 5 & 5 & 170 & 414190,70 & 4688802,36 & 1420,0 & 1 & 5 & 6 \\
\hline 121 & 414189,65 & 4688566,34 & 1429,0 & 1 & 3 & 4 & 171 & 414152,60 & 4688768,14 & 1416,4 & 1 & 7 & 8 \\
\hline 122 & 414186,58 & 4688567,32 & 1428,0 & 4 & 3 & 7 & 172 & 414178,68 & 4688779,98 & 1419,6 & 3 & 7 & 10 \\
\hline 123 & 414199,76 & 4688567,81 & 1431,0 & 1 & 5 & 6 & 173 & 414177,57 & 4688748,91 & 1426,3 & 3 & 5 & 8 \\
\hline 124 & 414204,84 & 4688571,53 & 1431,5 & 4 & 5 & 9 & 174 & 414204,94 & 4688757,04 & 1433,7 & 4 & 3 & 7 \\
\hline 127 & 414251,14 & 4688564,44 & 1430,0 & 1 & 7 & 8 & 177 & 414513,27 & 4688715,61 & 1447,6 & 1 & 1 & 2 \\
\hline 128 & 414295,28 & 4688563,59 & 1432,0 & 1 & 4 & 5 & 178 & 414597,43 & 4688687,31 & 1454,9 & 2 & 2 & 4 \\
\hline 129 & 414414,82 & 4688557,78 & 1440,2 & 2 & 6 & 8 & 179 & 414680,48 & 4688651,99 & 1456,0 & 2 & 4 & 6 \\
\hline 130 & 414390,40 & 4688542,47 & 1444,0 & 0 & 5 & 5 & 180 & 414819,75 & 4688665,86 & 1495,7 & 3 & 2 & 5 \\
\hline 131 & 414400,78 & 4688518,60 & 1453,6 & 1 & 9 & 10 & 181 & 413756,94 & 4687916,40 & 1505,5 & 0 & 2 & 2 \\
\hline 132 & 414275,75 & 4688317,44 & 1460,0 & 6 & 4 & 10 & 182 & 413788,09 & 4687884,93 & 1485,7 & 0 & 1 & 1 \\
\hline 133 & 414302,56 & 4688312,65 & 1463,7 & 4 & 3 & 7 & 183 & 413802,76 & 4687858,36 & 1482,0 & 1 & 3 & 4 \\
\hline 134 & 414312,99 & 4688329,31 & 1470,4 & 8 & 6 & 14 & 184 & 413831,47 & 4687866,30 & 1477,0 & 2 & 4 & 6 \\
\hline 135 & 414339,98 & 4688318,31 & 1473,7 & 7 & 5 & 12 & 185 & 413852,24 & 4687829,03 & 1491,5 & 6 & 4 & 10 \\
\hline 136 & 414367,04 & 4688302,52 & 1477,0 & 8 & 5 & 13 & 186 & 413813,75 & 4687841,86 & 1482,4 & 1 & 6 & 7 \\
\hline 137 & 414448,33 & 4688269,72 & 1506,7 & 8 & 4 & 12 & 187 & 413807,03 & 4687819,56 & 1492,2 & 0 & 4 & 4 \\
\hline 138 & 414470,51 & 4688256,79 & 1510,8 & 7 & 4 & 11 & 188 & 413768,54 & 4687843,69 & 1487,0 & 2 & 3 & 5 \\
\hline 139 & 414493,60 & 4688265,56 & 1509,3 & 5 & 2 & 7 & 189 & 413814,98 & 4687786,57 & 1510,2 & 8 & 5 & 13 \\
\hline 140 & 414416,00 & 4688336,24 & 1492,6 & 3 & 1 & 4 & 190 & 413778,01 & 4687786,57 & 1507,2 & 8 & 6 & 14 \\
\hline 141 & 414471,89 & 4688339,93 & 1506,0 & 2 & 4 & 6 & 191 & 413767,63 & 4687752,97 & 1520,0 & 5 & 6 & 11 \\
\hline 142 & 414555,50 & 4688332,54 & 1529,3 & 1 & 6 & 7 & 192 & 413734,33 & 4687689,74 & 1552,8 & 3 & 4 & 7 \\
\hline 143 & 414605,85 & 4688319,61 & 1530,1 & 1 & 4 & 5 & 193 & 413659,80 & 4687624,37 & 1584,0 & 2 & 3 & 5 \\
\hline 144 & 414743,97 & 4688227,68 & 1477,7 & 4 & 3 & 7 & 194 & 413573,86 & 4687594,43 & 1591,2 & 0 & 2 & 2 \\
\hline 145 & 414751,82 & 4688182,88 & 1488,6 & 1 & 5 & 6 & 195 & 413617,34 & 4687663,16 & 1560,9 & 1 & 2 & 3 \\
\hline 146 & 414749,05 & 4688155,16 & 1500,3 & 2 & 4 & 6 & 196 & 413702,87 & 4687799,10 & 1499,9 & 1 & 4 & 5 \\
\hline 147 & 414743,04 & 4688132,99 & 1512,4 & 5 & 3 & 8 & 197 & 414097,69 & 4688158,51 & 1436,7 & 7 & 3 & 10 \\
\hline 148 & 414674,68 & 4688151,00 & 1532,7 & 7 & 6 & 13 & 198 & 414100,34 & 4688179,70 & 1435,0 & 6 & 3 & 9 \\
\hline
\end{tabular}


TABLE I. Continued.

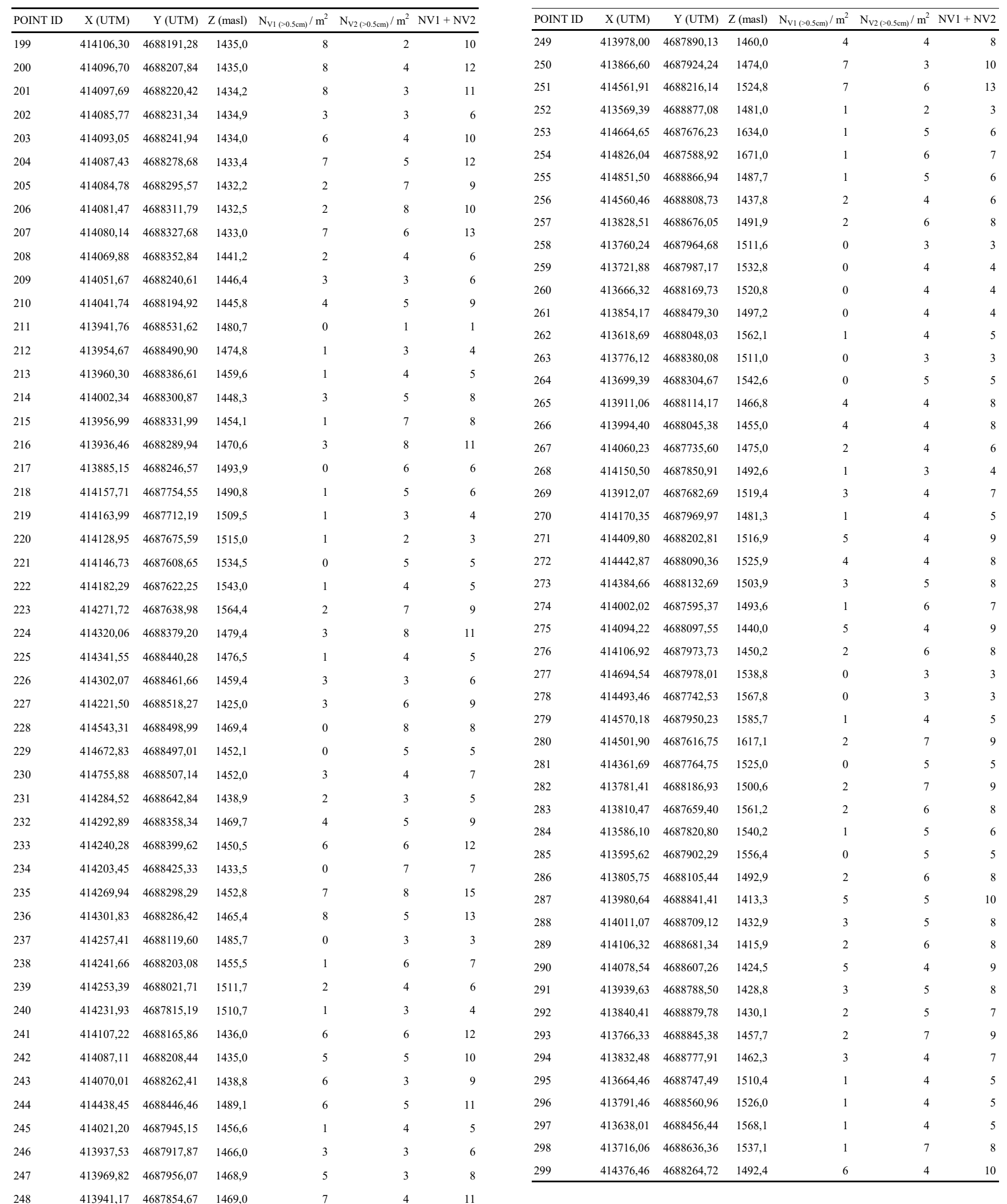




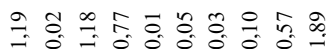

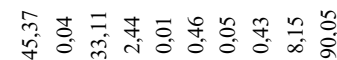

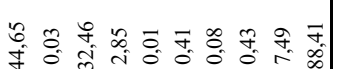

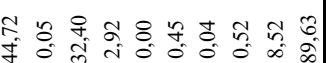

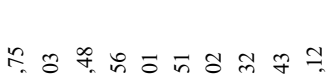

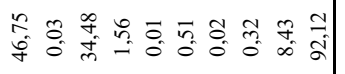

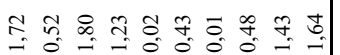

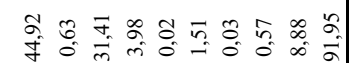

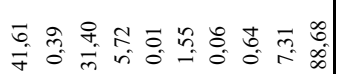
(1)

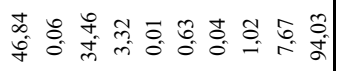

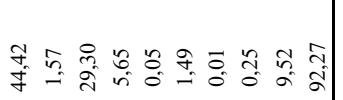
(1)

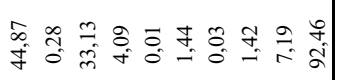

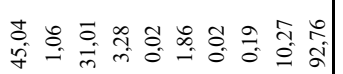

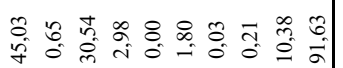

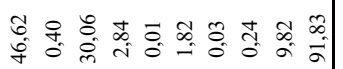

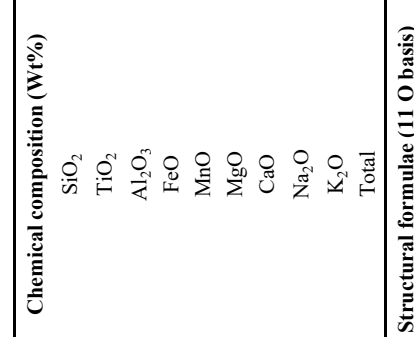

$\begin{array}{llll}0 & 0 \\ 0 & 0 & 0 & 0\end{array}$

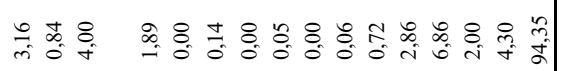

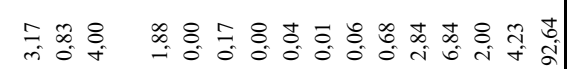

mind

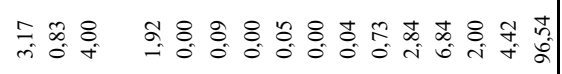

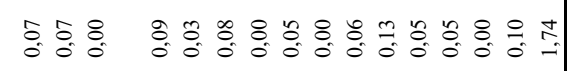

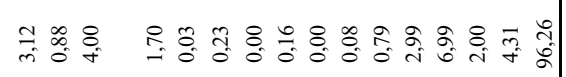

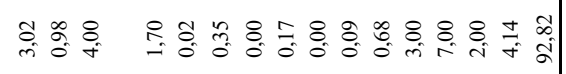

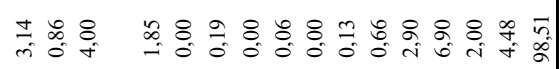

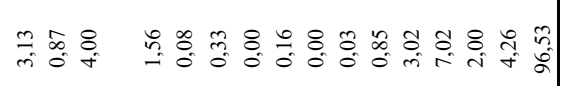

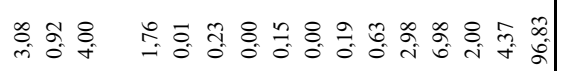

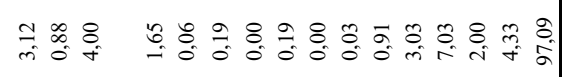

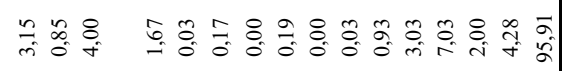

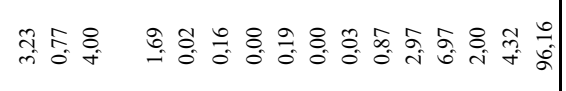

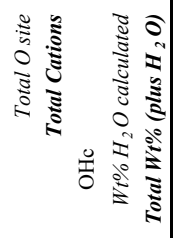




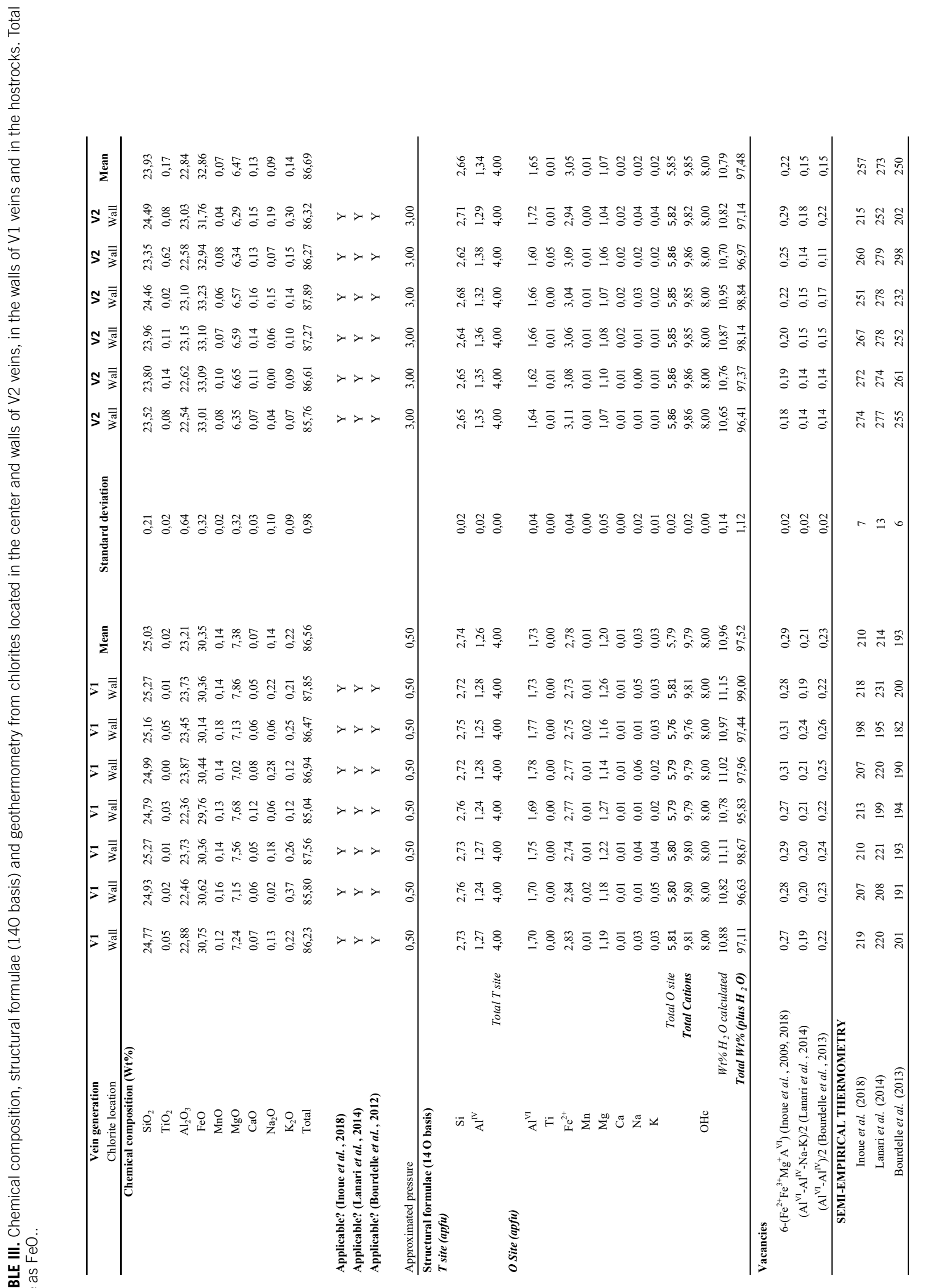




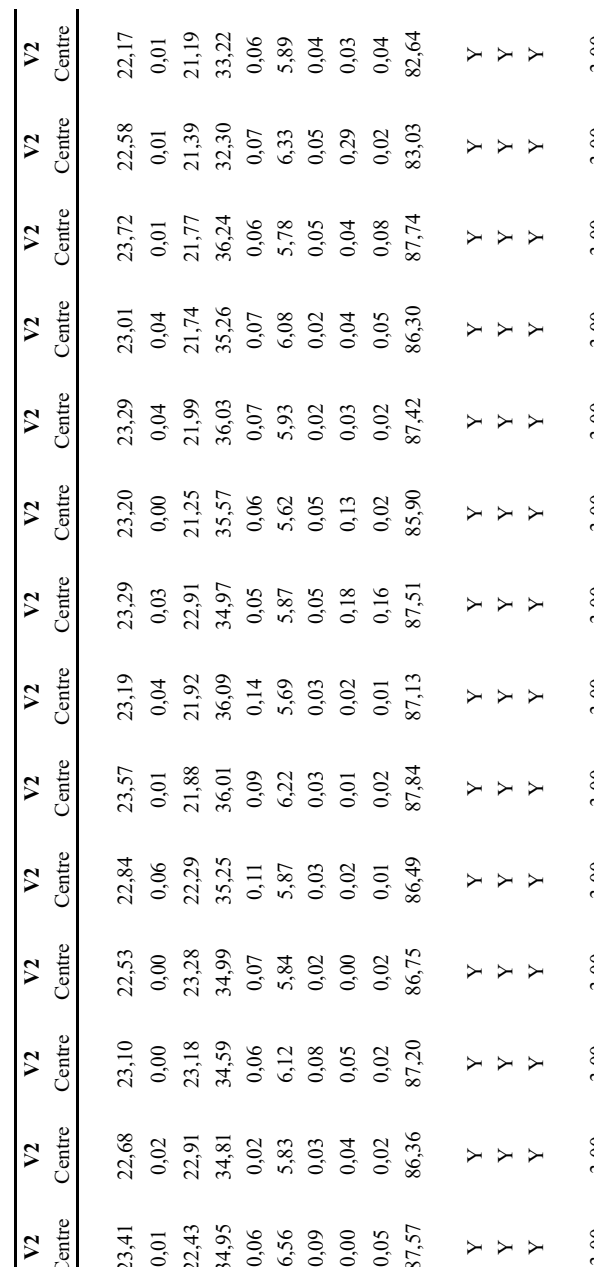
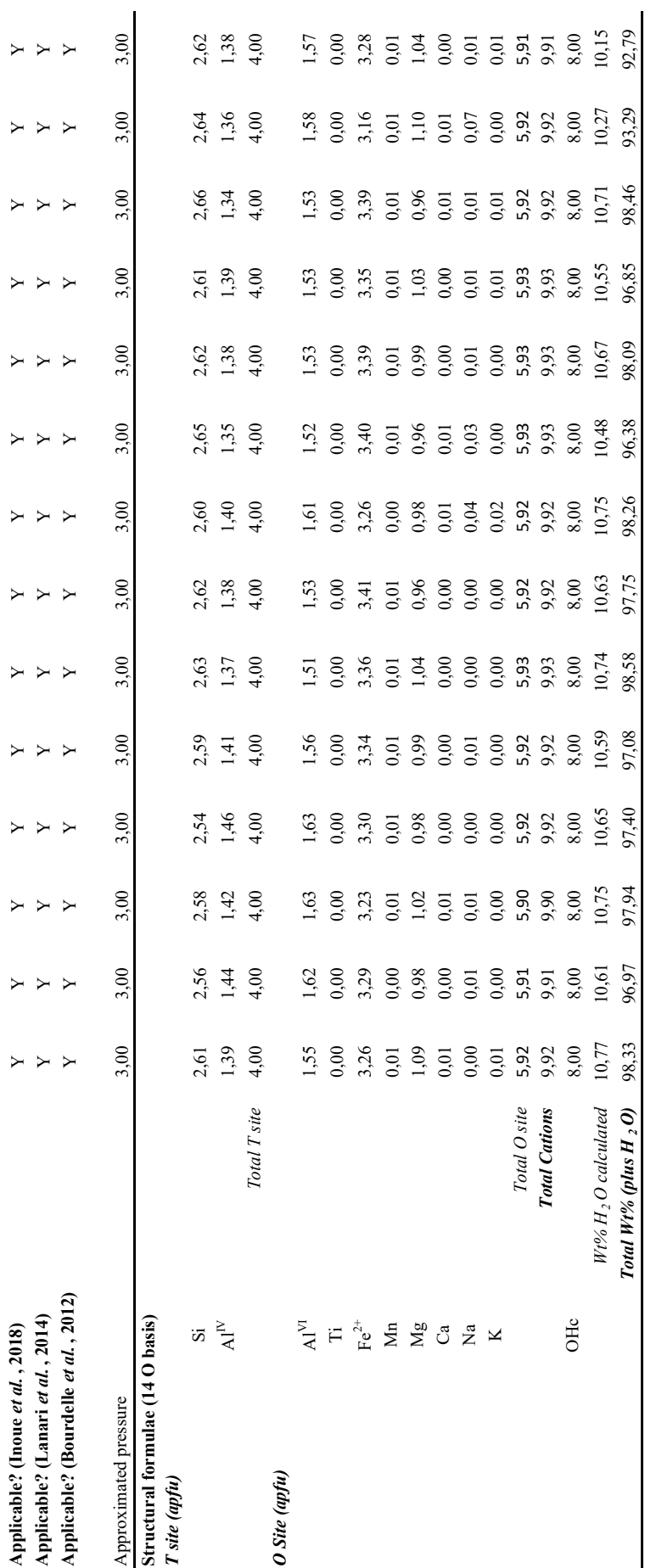

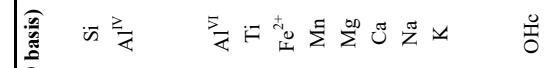

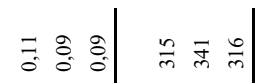

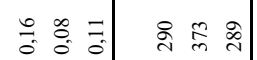
$=$ :

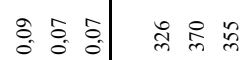

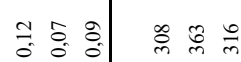

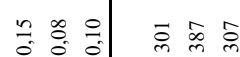

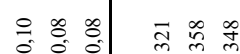

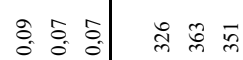

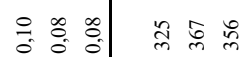

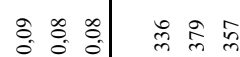

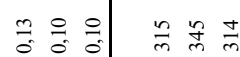
=. 응 品竞

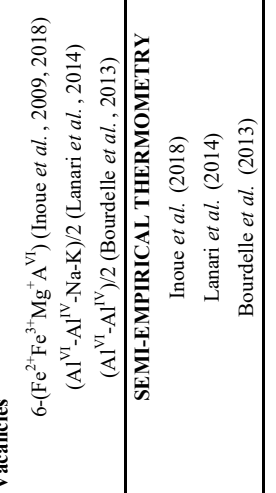




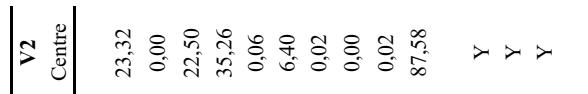

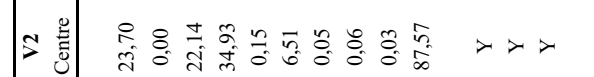

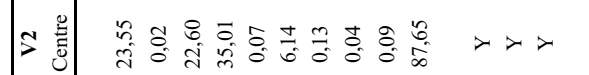

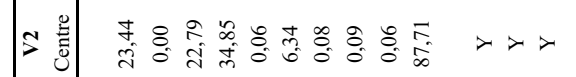

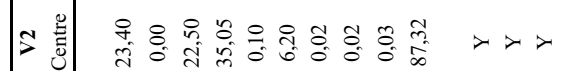

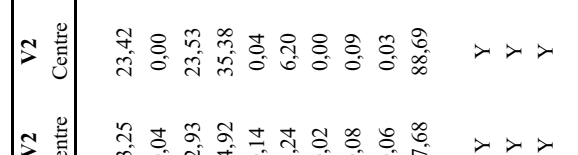

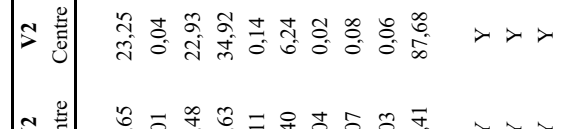

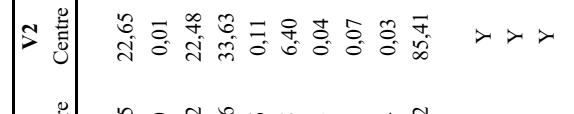

$\approx$ 蓄

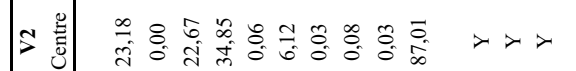

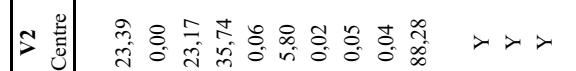

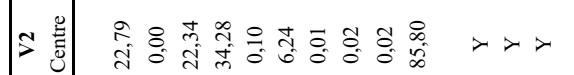



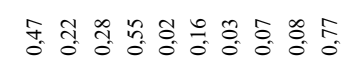

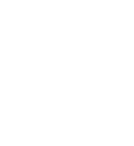

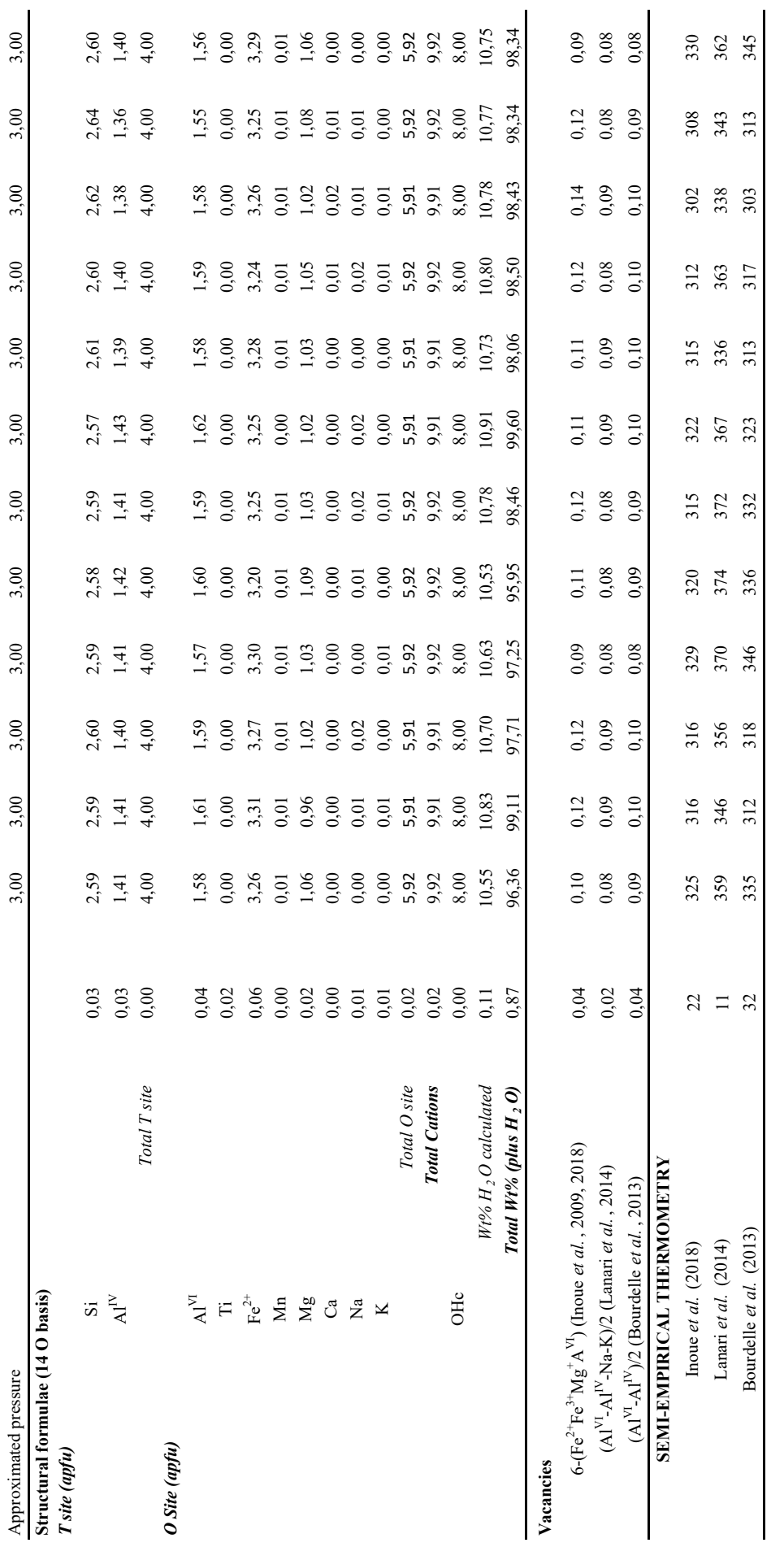

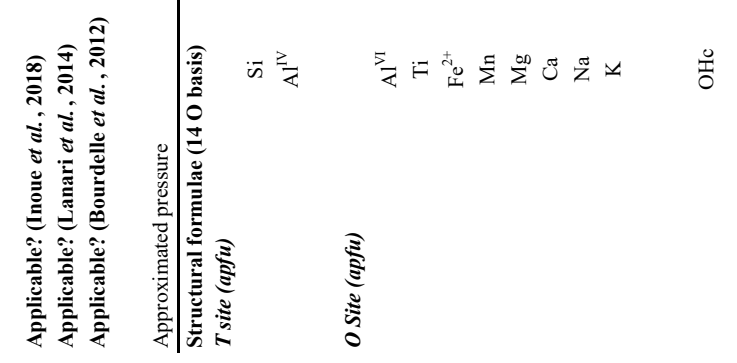




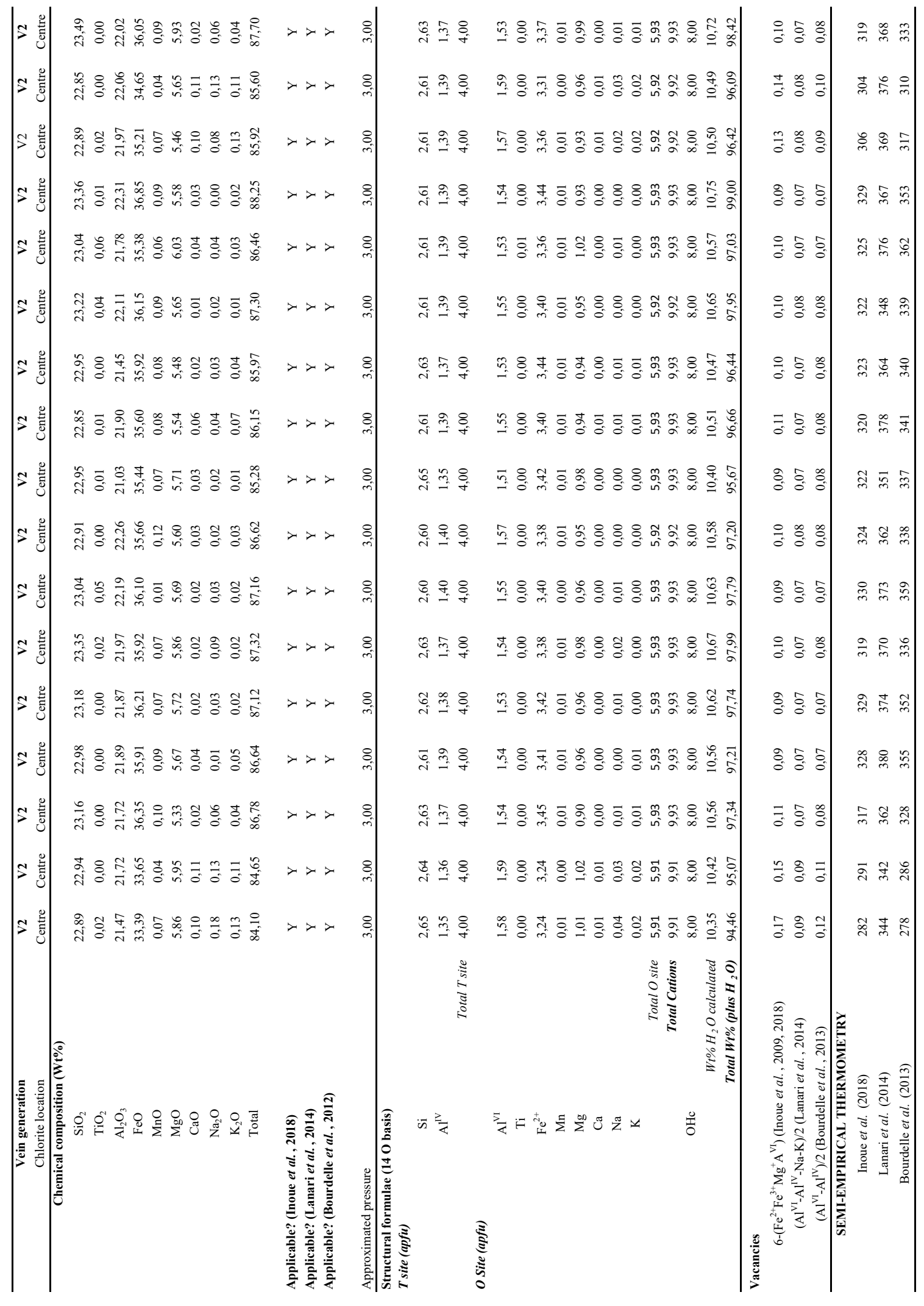




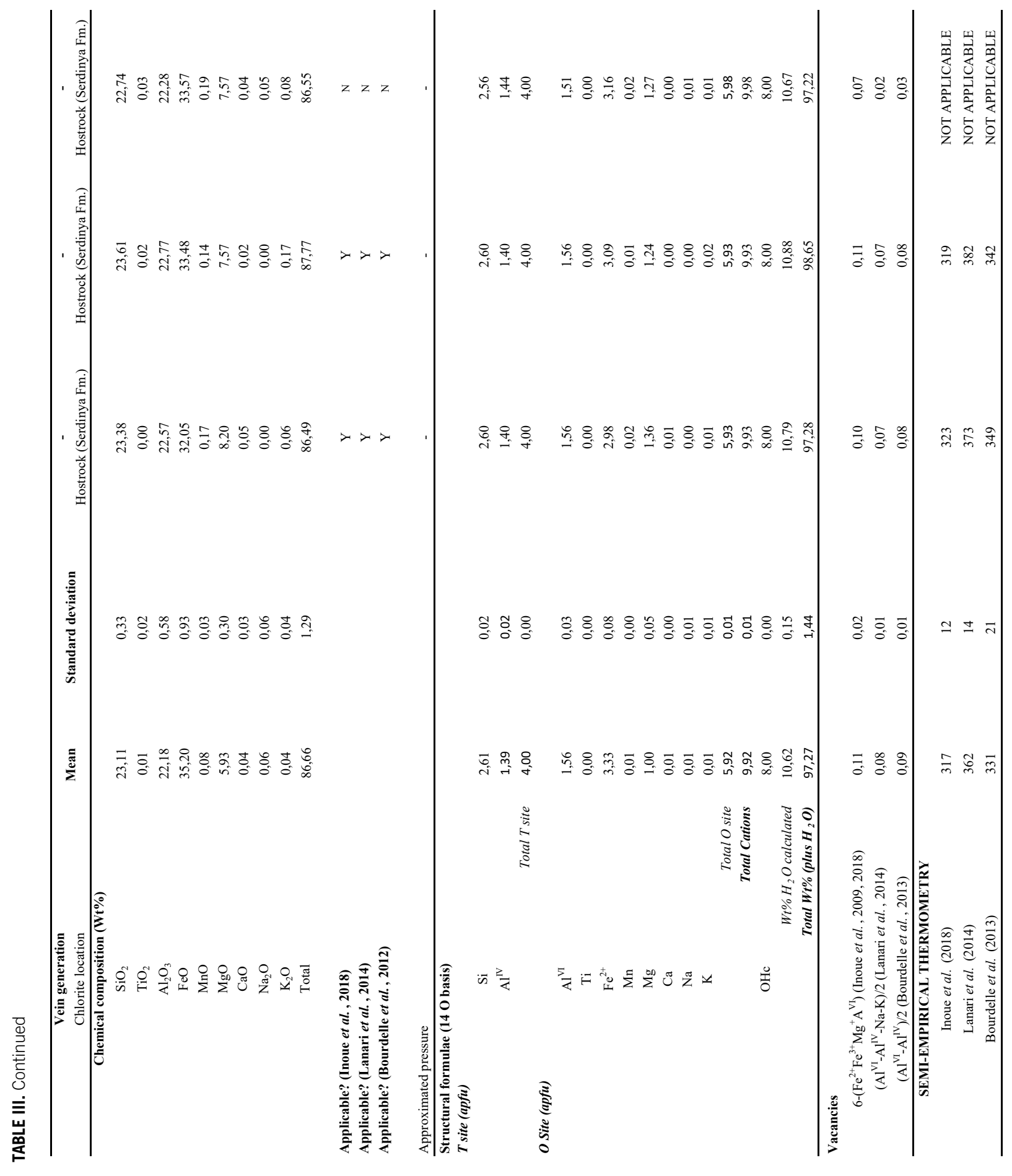




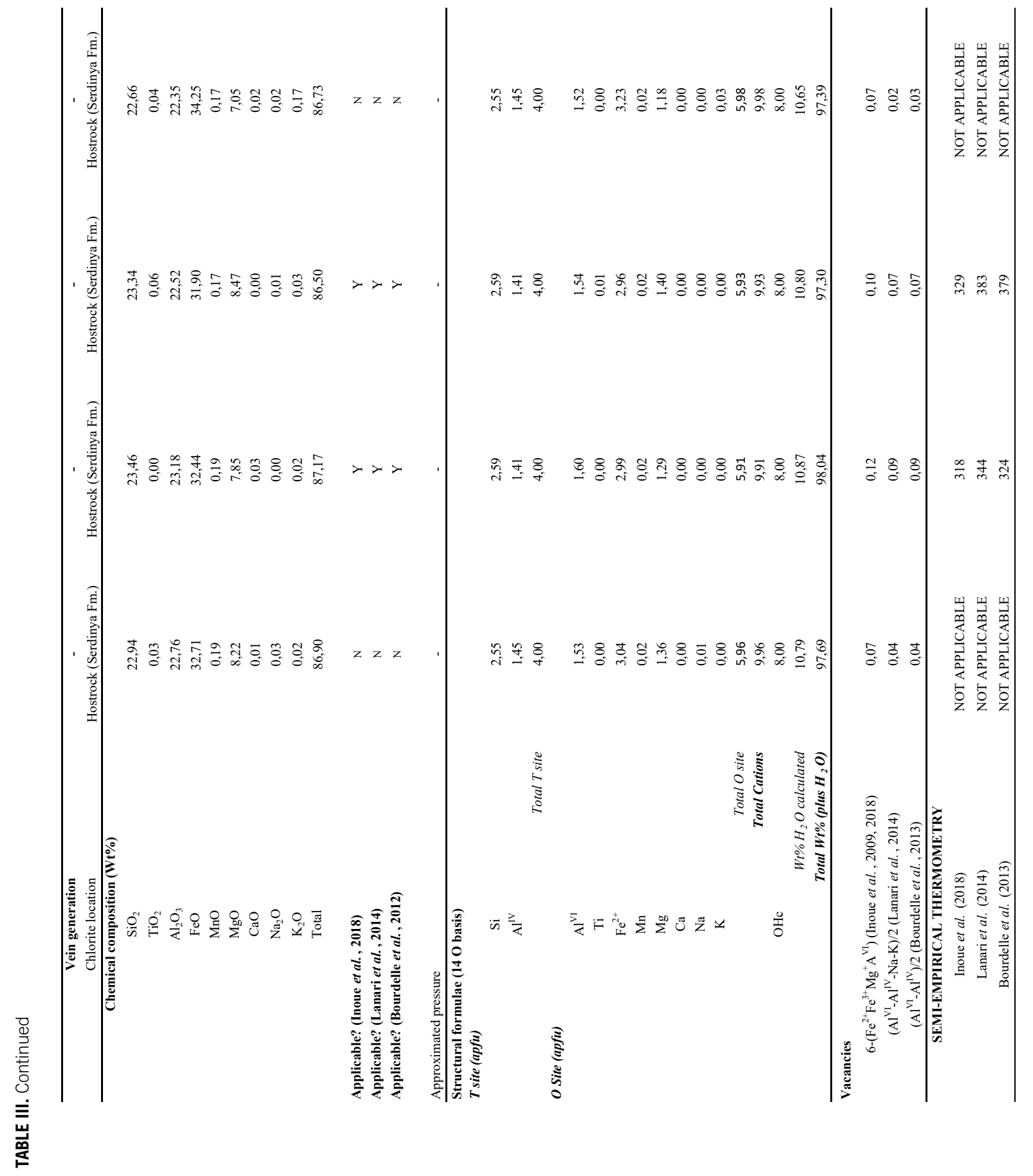




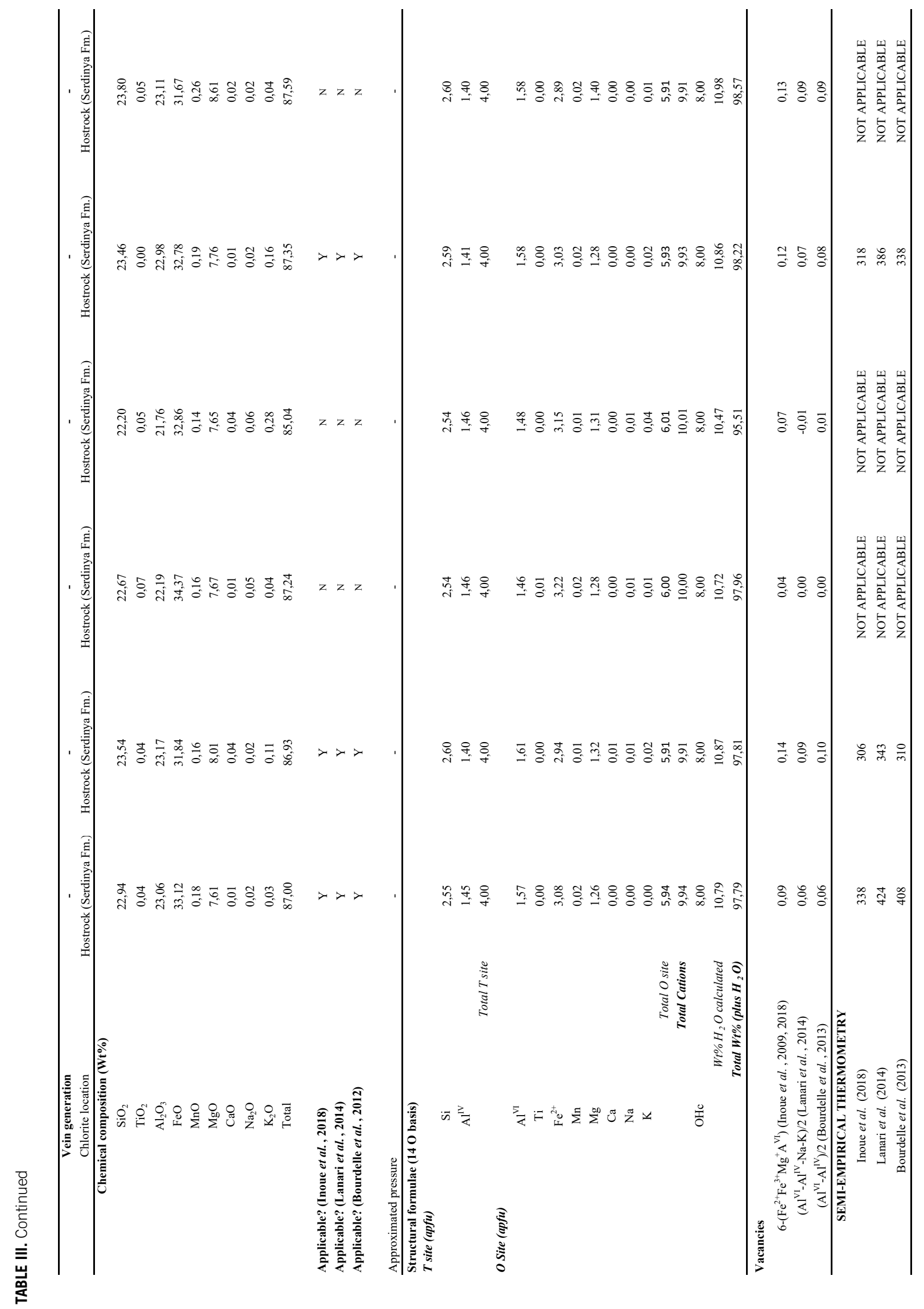




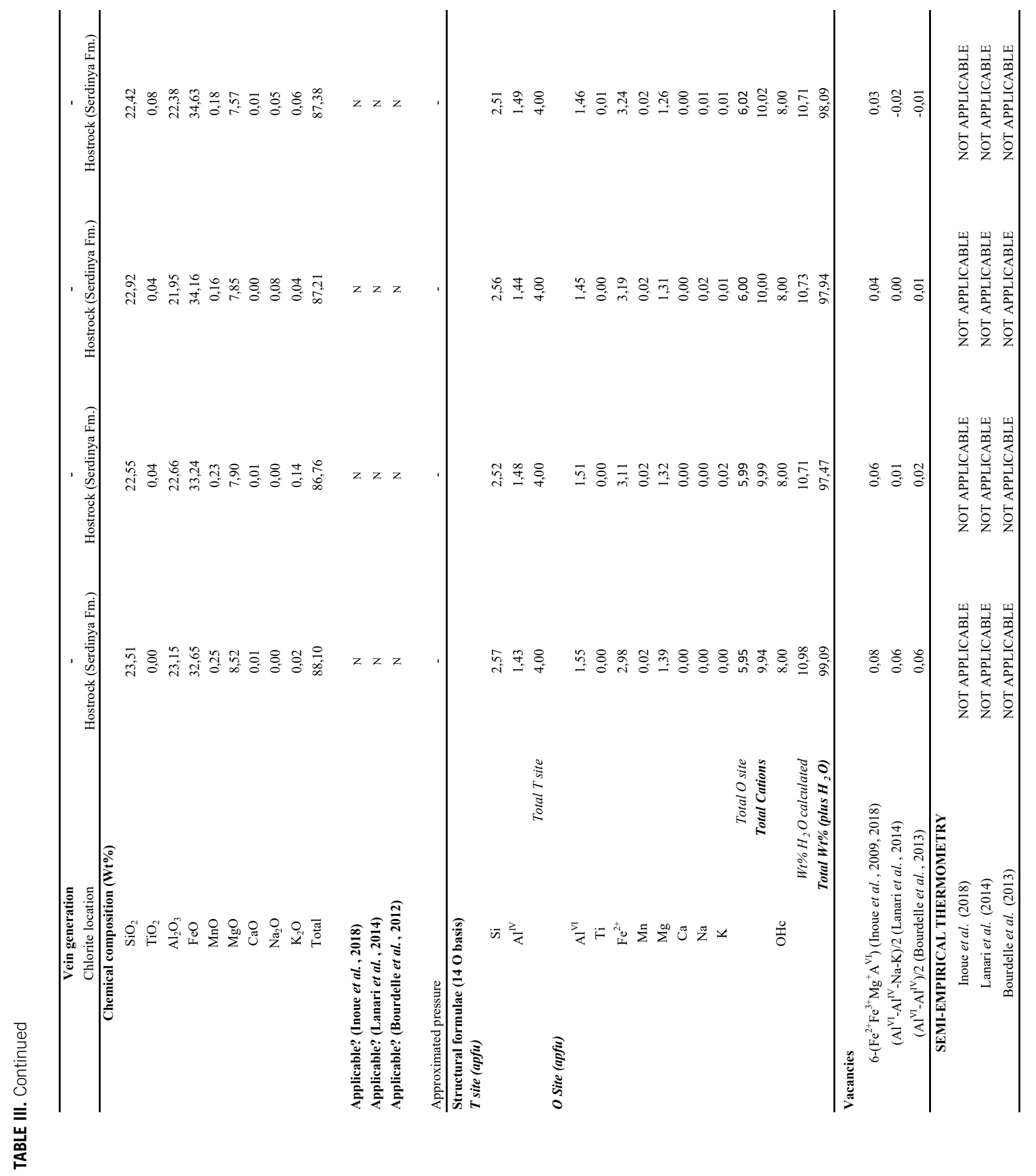




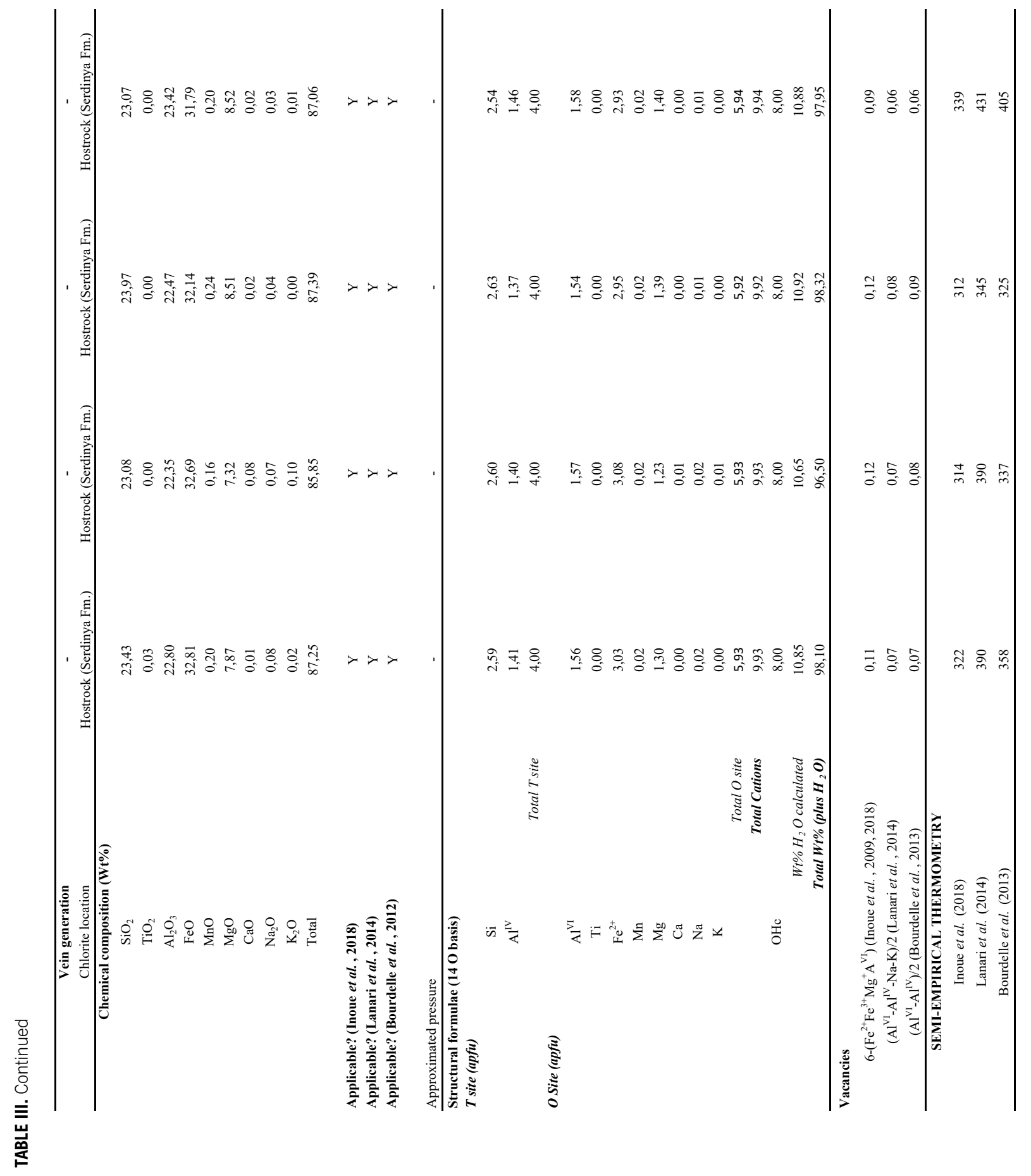




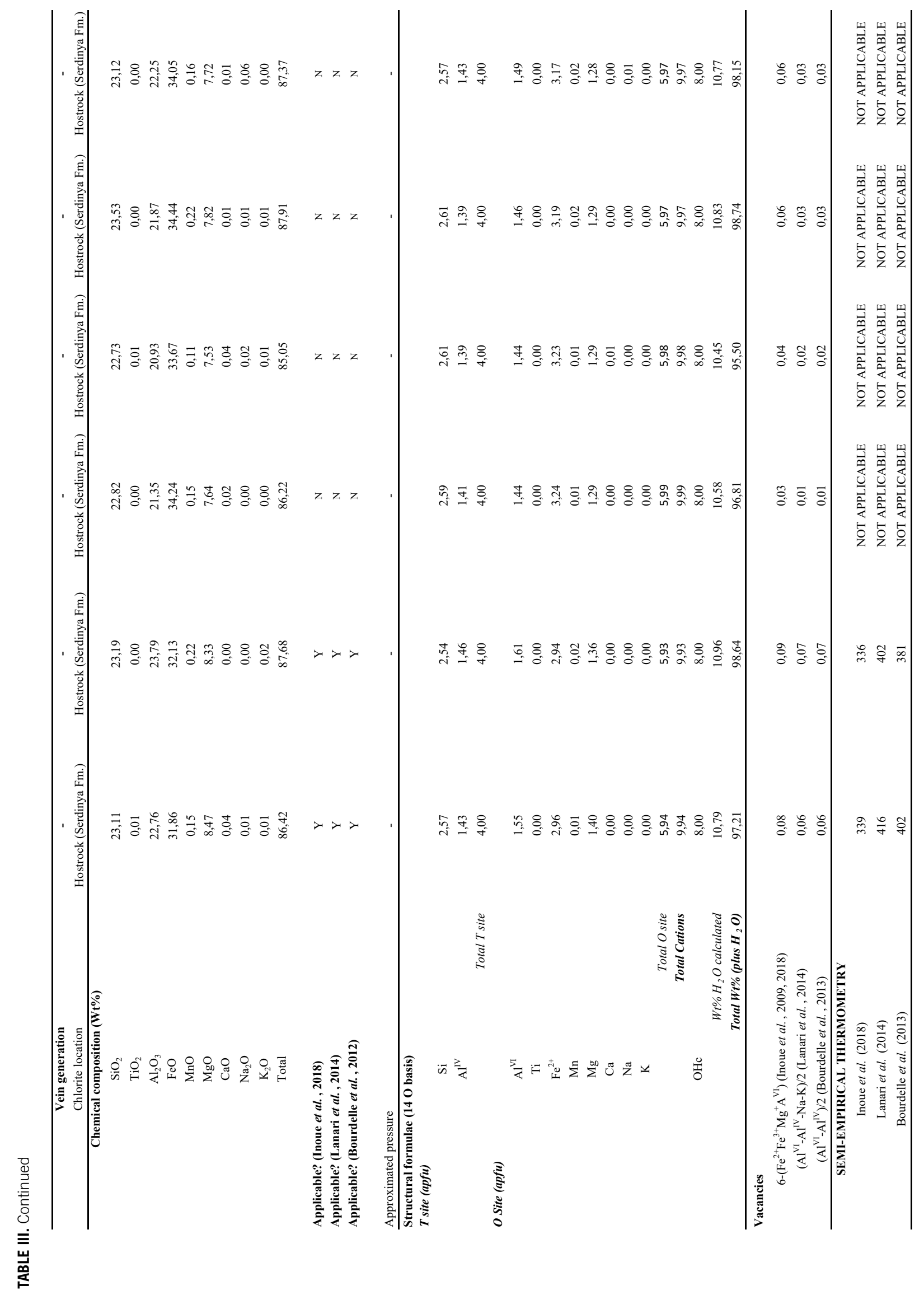




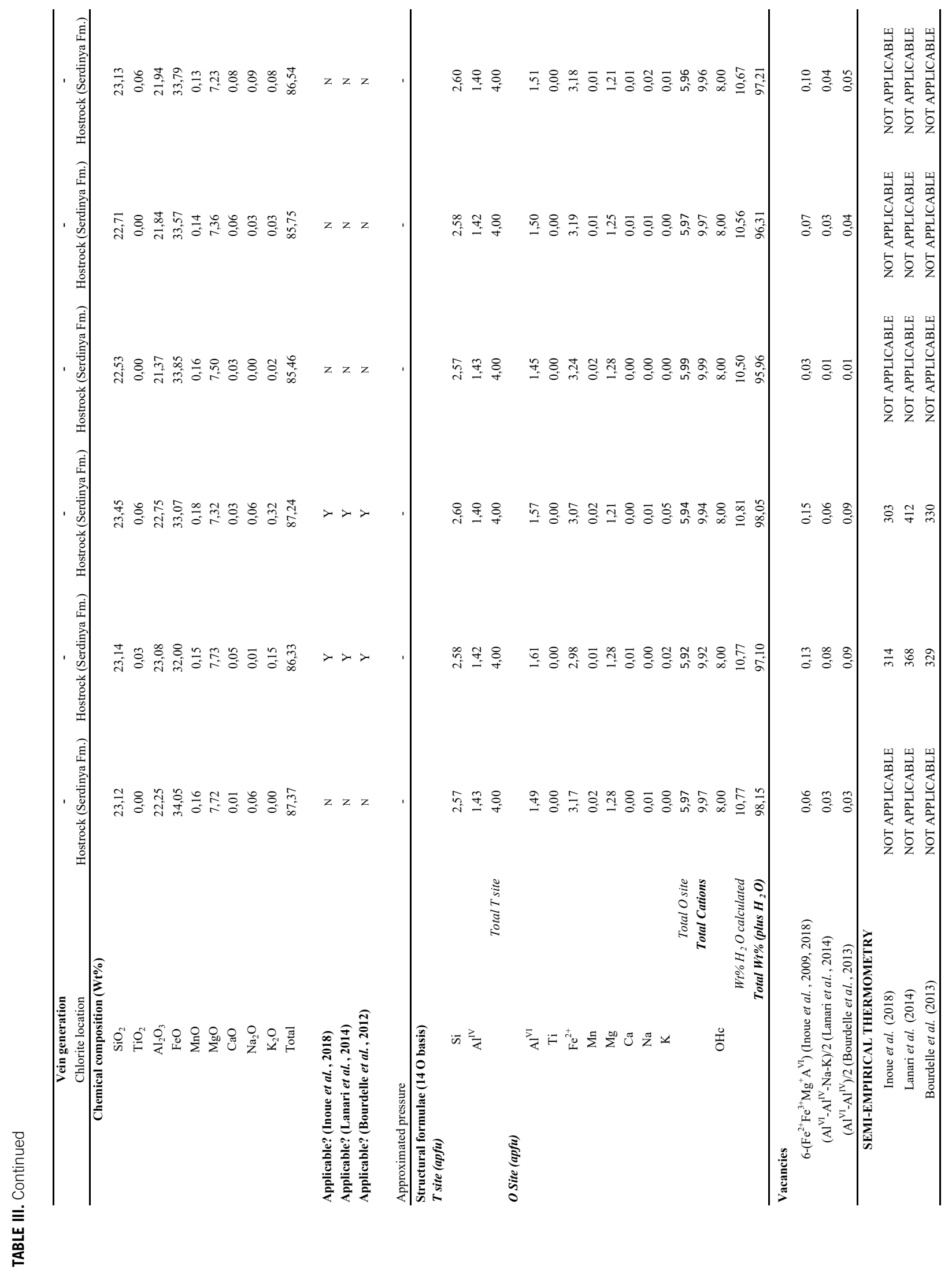




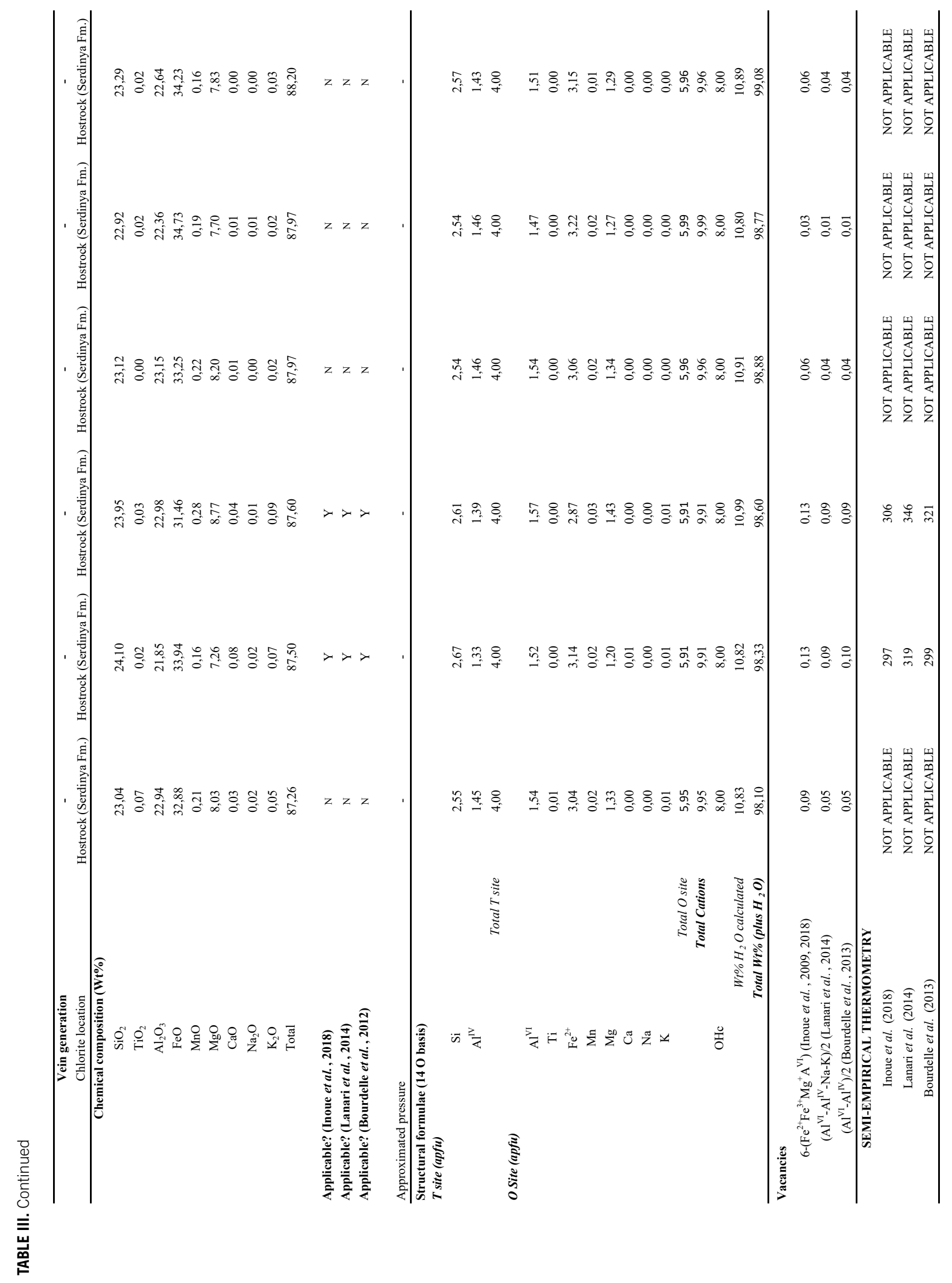




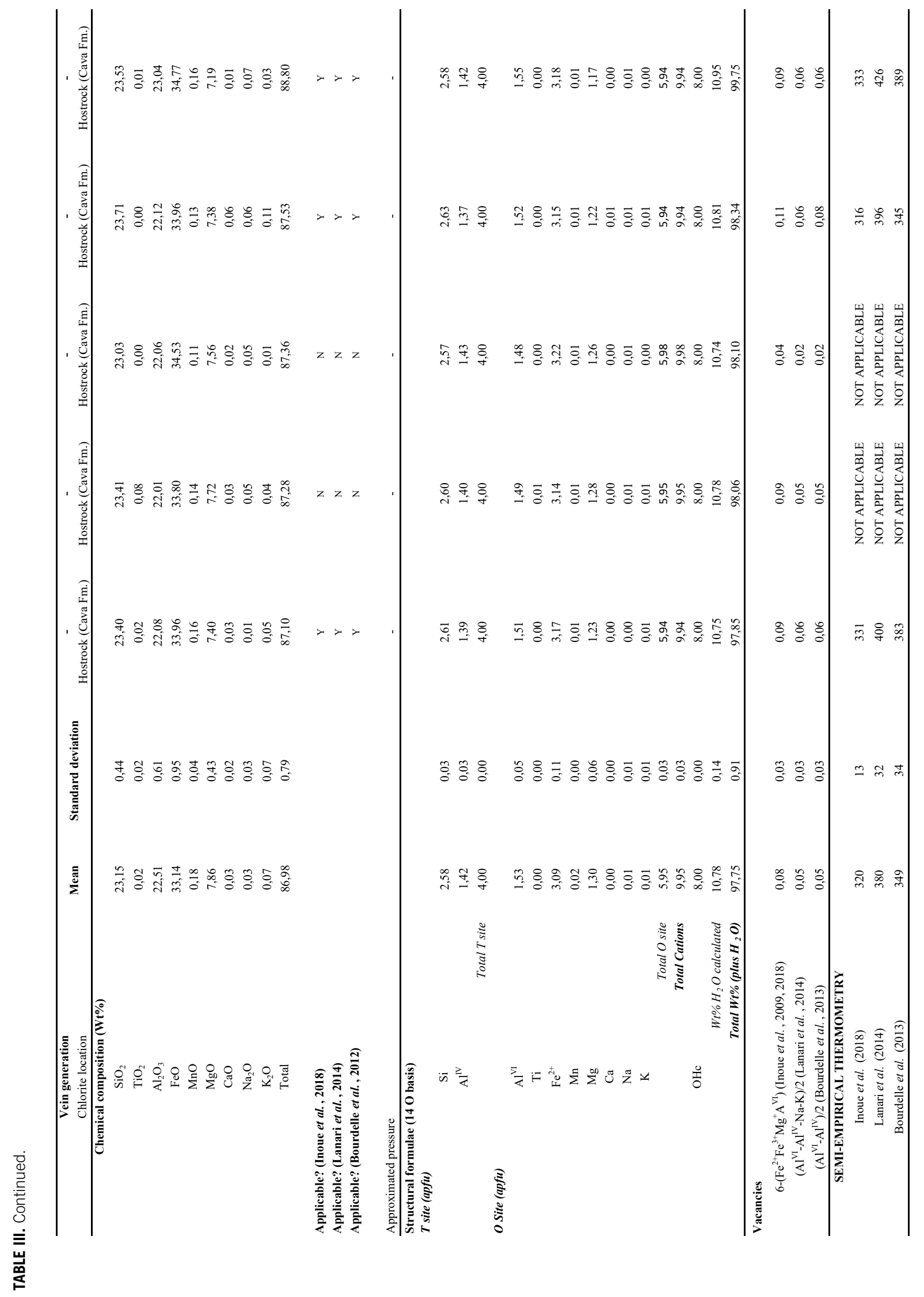



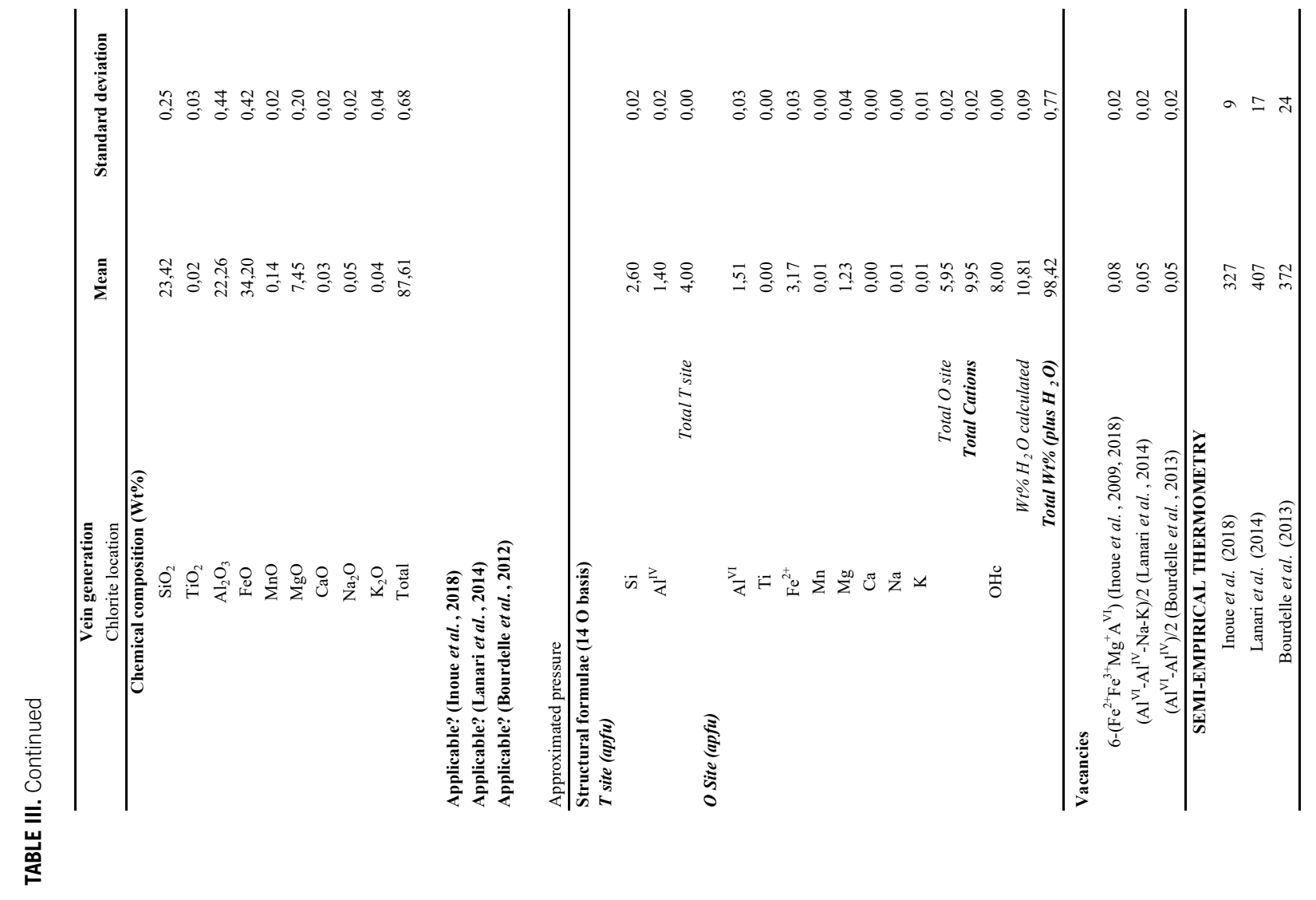